\title{
WestVirginiaUniversity
}

THE RESEARCH REPOSITORY @ WVU

Graduate Theses, Dissertations, and Problem Reports

2016

\section{Nutritional Consequences of Various Ingredients in Broilers, Turkeys, and Swine}

Kolby L. Foltz

Follow this and additional works at: https://researchrepository.wvu.edu/etd

\section{Recommended Citation}

Foltz, Kolby L., "Nutritional Consequences of Various Ingredients in Broilers, Turkeys, and Swine" (2016). Graduate Theses, Dissertations, and Problem Reports. 5607.

https://researchrepository.wvu.edu/etd/5607

This Thesis is protected by copyright and/or related rights. It has been brought to you by the The Research Repository @ WVU with permission from the rights-holder(s). You are free to use this Thesis in any way that is permitted by the copyright and related rights legislation that applies to your use. For other uses you must obtain permission from the rights-holder(s) directly, unless additional rights are indicated by a Creative Commons license in the record and/ or on the work itself. This Thesis has been accepted for inclusion in WVU Graduate Theses, Dissertations, and Problem Reports collection by an authorized administrator of The Research Repository @ WVU. For more information, please contact researchrepository@mail.wvu.edu. 
Nutritional Consequences of Various Ingredients in Broilers, Turkeys, and Swine

Kolby L. Foltz

Thesis submitted

to the Davis College of Agriculture, Natural Resources and Design

at West Virginia University

in partial fulfillment of the requirements for the degree of

Master of Science in

Animal and Food Science

Joseph S. Moritz, Ph.D., Chair

Robert L. Taylor, Jr., Ph.D.

Janet C. Tou, Ph.D.

Department of Animal and Nutritional Science

Morgantown, West Virginia

2016

Keywords: chelated zinc, corn particle size, broiler performance, phytase, transgenic corn, turkey performance, algae biomass, swine

Copyright 2016 K. L. Foltz 


\title{
ABSTRACT \\ Nutritional Consequences of Various Ingredients in Broilers, Turkeys, and Swine
}

\author{
Kolby L. Foltz
}

Experiments were conducted to evaluate various ingredients' effects on broiler, turkey, and porcine performance, as well as feed mill efficacy. In chapter 2, the effects of zinc ( $\mathrm{Zn})$ supplement source and corn particle size on broiler performance, breast yield, and tibia ash were assessed from d 1-40. Zinc treatments included a basal diet (no added Zn), $80 \mathrm{mg} / \mathrm{kg} \mathrm{Zn}$ sulfate, and three diets with $40 \mathrm{mg} / \mathrm{kg} \mathrm{Zn}$ sulfate $+40 \mathrm{mg} / \mathrm{kg}$ of varying $\mathrm{Zn}$ amino acid chelates, and corn particle size was either $550 \mu \mathrm{m}$ or $1,050 \mu \mathrm{m}$. Broilers fed diets containing $550 \mu \mathrm{m}$ corn had higher feed intake (FI) and live weight gain (LWG) from d 1-22, while feed conversion ratio (FCR) was improved for broilers fed diets with 1,050 $\mu \mathrm{m}$ corn from d 23-40 and d 1-40. Diets supplemented with $80 \mathrm{mg} / \mathrm{kg} \mathrm{Zn}$ improved broiler performance compared to the diet without supplemental $\mathrm{Zn}$, but no differences were observed between $\mathrm{Zn}$ sources for performance or tibia ash. In chapter 3, a study was conducted to determine mix uniformity, thermal stability, and pellet quality of diets supplemented with two particle sizes ( 2 or $3 \mathrm{~mm}$ ) of transgenic phytase corn (TPC) and two concentrations $(5,100$ or $15,300 \mathrm{FTU} / \mathrm{kg}$ - AOAC 2000.12) of granulated phytase. Mix uniformity was determined by calculating mixer coefficient of variation (CV) using chloride ion concentration and phytase activity of ten mash samples taken from various locations within the mixer. Each phytase diet was steam conditioned and pelleted at 80,85 , and $90^{\circ} \mathrm{C}$ and activity was measured to determine enzyme recovery. The results indicated that mix uniformity was better for granulated phytases than TPC, and mix uniformity was improved for $2 \mathrm{~mm}$ TPC compared to $3 \mathrm{~mm}$ TPC. The $2 \mathrm{~mm}$ TPC had the highest recovery at $80^{\circ} \mathrm{C}$, while granulated phytases were superior to TPC products at $90^{\circ} \mathrm{C}$. In chapter 4 , three studies were conducted to determine porcine palatability of corn-soybean based diets supplemented with oil-extracted microalgae and subsequent performance. In study 1 , Duroc x Yorkshire-Landrace crossbred pigs were fed diets containing either $0,1,2$, or $4 \%$ oil-extracted microalgae for a $14 \mathrm{~d}$ grow-out period. Average daily gain (ADG), average daily feed intake (ADFI), and gain:feed (G:F) were similar among all treatments and pellet durability was numerically higher for the $4 \%$ microalgae diet. In studies 2 and 3 , pigs were fed diets containing either 0 or $4 \%$ microalgae. All performance metrics (ADG, ADFI, and G:F) were similar among all treatments suggesting that oil-extracted microalgae can be used as a feed ingredient for swine. In chapter 5, the performance and carcass characteristics of two commercial turkey hen strains (Nicholas and Hybrid) and a test product turkey hen strain were evaluated from d 1-125. Secondary objectives of the study were to determine the effect of an elevated nutrient diet for feathering in the test product strain, and to determine genetic differences in lysine $\alpha$-ketoglutarate reductase (LKR) activity at $d 125$. Hybrid hens had the largest LWG from wk 1-4, while Nicholas hens had larger LWG from wk 13-16. At d 125, performance, hot breast yield, and fat pad yield were similar among all three hen strains. The LKR activity was not different among strains, likely due to lack of performance differences among treatments. 


\section{Acknowledgements}

This work could not have been accomplished without the help of several people along the way. First, I would like to thank my major professor Dr. Joe Moritz. I am eternally grateful for the endless opportunities and knowledge that you have given me over the past two years. It has been an honor to work with you and I look forward to being colleagues and friends for many years to come. I would also like to thank my other committee members, Dr. Robert Taylor, Jr. and Dr. Janet Tou. Dr. Taylor, it has been a privilege to have such a distinguished member of the poultry science community on my committee. Thank you for always offering a friendly conversation and sharing your knowledge of poultry breeding and immunology. Dr. Tou, thank you for your continual words of encouragement and for always sharing your life advice with me. I would also like to thank the staff of the Division of Animal and Nutritional Sciences, especially Gretchen Riggs, Bonnie Wood, and Lindsay Tripplett, and Rick Wood for his technical help at the farm. I would like to acknowledge my lab mates, John Boney, Brian Glover, Dani Reese, Mark Lemons, Ashley Evans, Tyler Rigby, Tori Homan, and the undergraduates for their help. A lot of long hours have been spent together at the research barn, feed mill, conferences, and sometimes just having fun. Last but not least, I would like to thank my parents, Kevin and Lora, and brothers, Kollin and Korey, for their continued love and support throughout this process. I would not be where I am today without them. 


\section{TABLE OF CONTENTS}

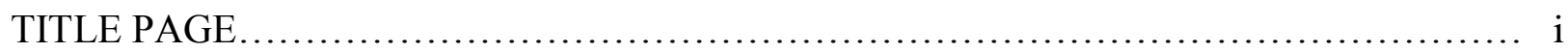

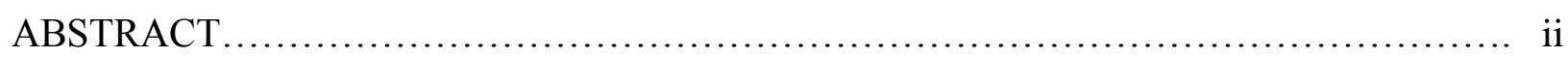

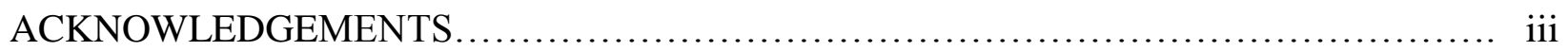

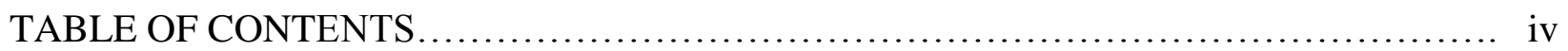

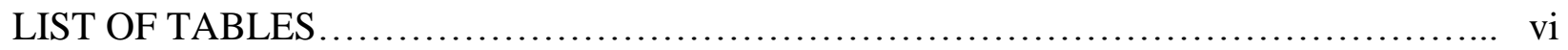

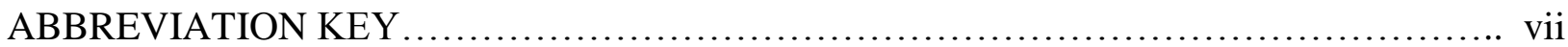

\section{CHAPTER ONE}

LITERATURE REVIEW $\ldots \ldots \ldots \ldots \ldots \ldots \ldots \ldots \ldots \ldots \ldots \ldots \ldots \ldots \ldots \ldots \ldots \ldots \ldots \ldots \ldots \ldots \ldots, 1$

Pellet Quality............................................................ 1

Corn Particle Size.......................................................... 2

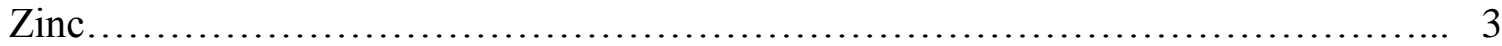

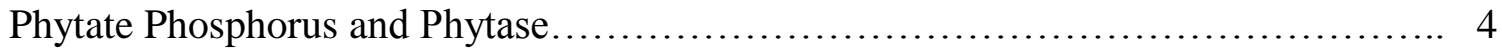

Mix Uniformity......................................................... 5

Transgenic Seeds......................................................... 6

Biofuel and Microalgae................................................... 7

Turkey Genetics......................................................... 8

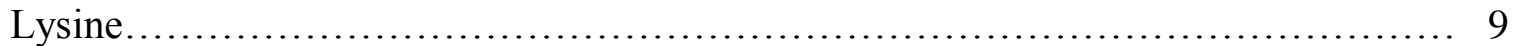

References.................................................................. 10

\section{CHAPTER TWO}

EFFECT OF ZINC SUPPLEMENTATION SOURCE AND CORN PARTICLE SIZE ON 40-D BROILER PERFORMANCE............................................... 17

Summary................................................................ 18

Description of Problem.......................................................... 19

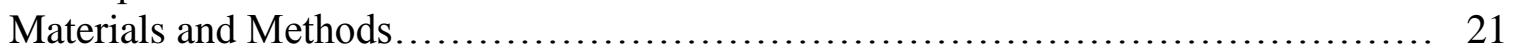

Results and Discussion........................................................ 24

Conclusions and Applications................................................ 26

References and Notes...................................................... 27

Tables and Figures...................................................... 30 


\section{CHAPTER THREE}

TRANSGENIC PHYTASE CORN AND GRANULATED PHYTASE EFFECTS ON MIX UNIFORMITY, THERMAL STABILITY, AND PELLET QUALITY .................... 35

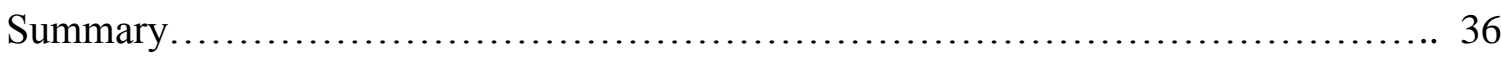

Description of Problem...................................................... 37

Materials and Methods........................................................ 38

Results and Discussion..................................................... 41

Conclusions and Applications................................................. 43

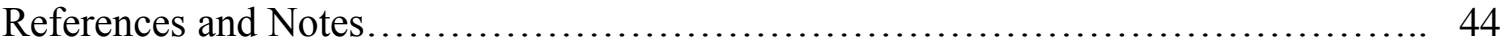

Tables and Figures................................................................... 48

\section{CHAPTER FOUR}

PORCINE PALATABILITY OF CORN-SOYBEAN BASED DIETS SUPPLEMENTED WITH OIL-EXTRACTED MICROALGAE AND SUBSEQUENT PERFORMANCE ............. 57

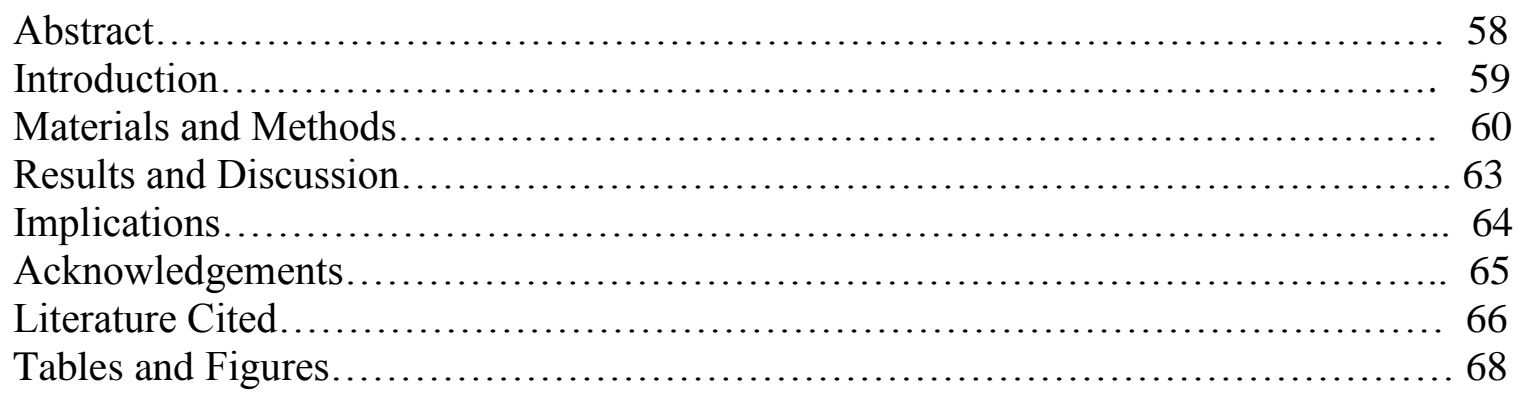

\section{CHAPTER FIVE}

PERFORMANCE AND CARCASS CHARACTERISTICS OF THREE COMMERCIAL TURKEY STRAINS AND A NOVEL STRAIN REARED FROM D 1-125................ 73

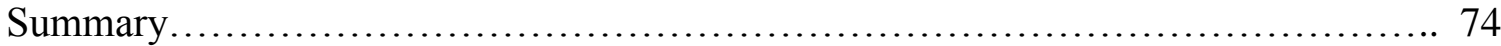

Description of Problem......................................................... 75

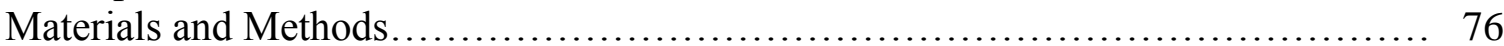

Results and Discussion....................................................... 80

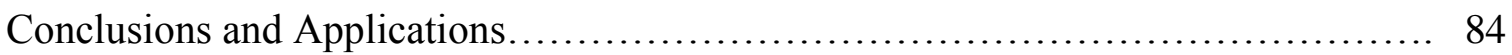

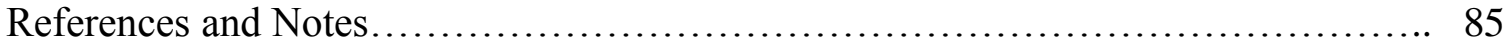

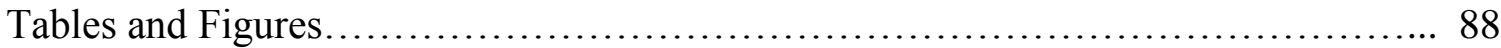

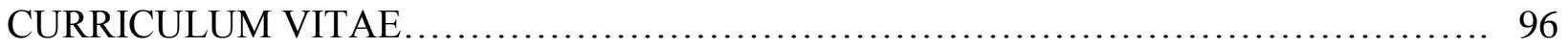




\section{LIST OF TABLES}

\section{CHAPTER TWO}

Table 1. Diet composition of starter, grower, and finisher phases................ 30

Table 2. Analyzed corn particle size and descriptive feed manufacture data.......... 31

Table 3. Overall (d 1-40) Hubbard x Cobb straight-run broiler performance.......... 32

Table 4. Hubbard x Cobb straight-run broiler performance within starter, grower, and

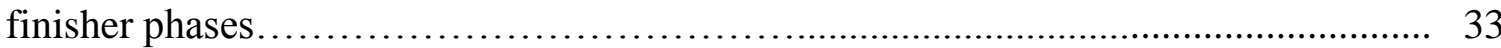

Table 5. d 40 hot breast yield and tibia ash analysis............................ 34

\section{CHAPTER THREE}

Table 1. Initial test product activity benchmarking........................... 48

Table 2. Composition of broiler starter experimental diet.......................... 49

Table 3. Actual corn particle size of TPC Corn products......................... 50

Table 4. Feed manufacture descriptive data.................................. 51

Table 5. Coefficient of variation based on chloride ion concentration and phytase activity in complete diet mash samples............................................. 52

Table 6. Dyed phytase corn particle analysis in mash feed......................... 53

Table 7. Dyed phytase corn particle analysis in pelleted feed...................... 54

Table 8. Post-pelleting enzyme activity relative recovery...................... 55

Table 9. Fines and pellet durability data.................................... 56

\section{CHAPTER FOUR}

Table 1. Nutrient composition of oil-extracted microalgae biomass ............... 68 Table 2. Composition of basal diets fed to Duroc x Yorkshire-Landrace growing pigs..69 Table 3. Pellet durability of corn-soybean meal based diets supplemented with oil-

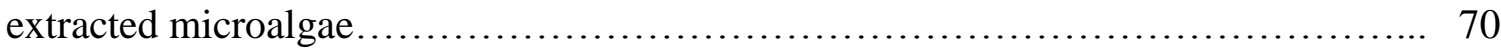

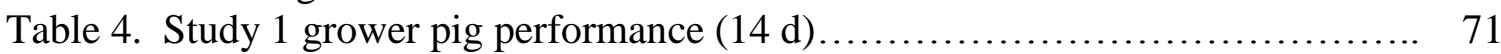

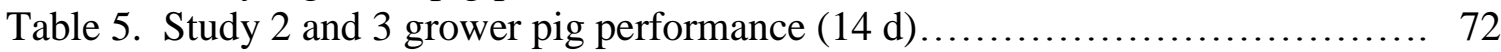

\section{CHAPTER FIVE}

Table 1. Composition (\%) of basal diets fed to commercial turkey hens............. 88

Table 2. Composition (\%) of elevated nutrient diets fed to commercial turkey hens... 89

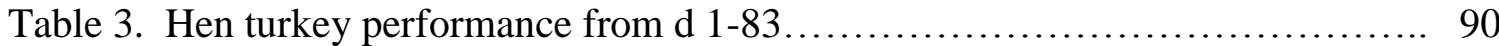

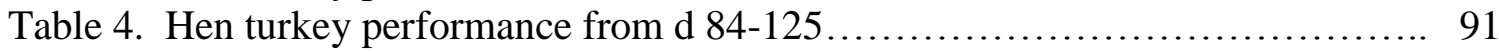

Table 5. Overall (d 1-125) hen turkey performance.......................... 92

Table 6. Feather scoring descriptive data (d 56 and d 112)..................... 93

Table 7. d 125 hot carcass characteristics and LKR activity..................... 94

Table 8. Carcass yield descriptive data from commercial processing plant on d 126.. 95 


\section{ABBREVIATION KEY}

GENERAL LIST

GMD = geometric mean diameter

$\mathrm{GSD}=$ geometric standard deviation

$\mathrm{Zn}=$ zinc

IP6 = myo-inositol 1,2,3,4,5,6-hexakis dihydrogen phosphate

$\mathrm{CV}=$ coefficient of variation

$\mathrm{EBW}=$ ending body weight

$\mathrm{FCR}=$ feed conversion ratio

$\mathrm{FI}=$ feed intake

LWG = live weight gain

$\mathrm{PDI}=$ pellet durability index

MPDI = modified pellet durability index

NHPT $=$ New Holmen pellet tester

$\mathrm{LKR}=$ lysine $\alpha$-ketoglutarate reductase

$\mathrm{LSD}=$ least significant difference

\section{CHAPTER ONE}

$\mathrm{d}=$ day

$\mathrm{GI}=$ gastrointestinal

$\mathrm{P}=$ phosphorus

$\mathrm{PP}=$ phytate-phosphorus

DDGS = distiller's dried grains with solubles

\section{CHAPTER TWO}

$\mathrm{GI}=$ gastrointestinal

$\mathrm{ZnSO}_{4}=$ zinc sulfate

$\mathrm{AA}=$ amino acid

Zn-gly = zinc-glycine amino acid chelate

$\mathrm{Zn}-\mathrm{AA}=$ zinc-amino acid complex

Zn-HMTBA = zinc-bis(-2-hydroxy-4-methylthio)butanoic acid

\section{CHAPTER THREE}

$\mathrm{P}=$ phosphorus

$\mathrm{TPC}=$ transgenic phytase corn

GEP1 = granulated $E$. coli phytase 1

GEP2 = granulated $E$. coli phytase 2

$\mathrm{SAS}=$ Statistical Analysis System

$\mathrm{T}_{m}=$ melting temperature 


\section{CHAPTER FOUR}

ASTM = American Society for Testing and Materials

$\mathrm{ADG}=$ average daily gain

$\mathrm{ADFI}=$ average daily feed intake

$\mathrm{G}: \mathrm{F}=$ gain:feed

\section{CHAPTER FIVE}

$\mathrm{SS}=$ Super Select

$\mathrm{EN}=$ elevated nutrient

$\mathrm{B} / \mathrm{S}=$ boneless/skinless

$\mathrm{BI}=$ bone-in

$\mathrm{WOG}=$ weight omitting giblets 


\section{LITERATURE REVIEW}

\section{Pellet Quality}

A majority of the work in this thesis involves the evaluation of various ingredients and/or factors affecting pellet quality. Pelleting is an expensive process, both in capital and energy costs, but the benefits are believed to outweigh costs (Behnke, 1996). Behnke (1994) associated the benefits of pelleting to improved bulk density, improved handling characteristics, decreased feed wastage, decreased selective feeding, reduction of feed pathogens, thermal modification of starch and protein, improved palatability, and ultimately improved animal performance. Jensen et al. (1962) observed that birds fed pelleted diets were able to consume more feed with a single peck, thus energy expenditure for feed prehension was reduced. Several studies have shown performance improvements when feeding pellets versus unprocessed mash (Reece et al., 1985; Wondra et al., 1995; Cutlip et al., 2008; Lilly et al., 2011). Due to associated benefits, eighty percent of non-ruminant animal feed in the U.S. is pelleted (Behnke, 2001). Within broilers and turkeys, pelleting is almost exclusively practiced.

Pellet quality is the ability of pellets to maintain structural integrity throughout processing, handling, transport, and conveyance to the feed pan. The quality of pellets is usually referred to in terms of pellet durability, but could be more appropriately termed "pellet survivability". Past research shows that increasing pellet durability improves bird performance when manufacture techniques do not compromise nutrient digestibility (Cutlip et al., 2008; Buchanan and Moritz, 2009; Lilly et al., 2011; Loar et al., 2014; Corey et al., 2014). Behnke (1994) noted that there are many factors that affect pellet quality, including: diet formulation, ingredient particle size, mash conditioning (duration, pressure, and temperature), production speed (feed flow and die), and die specifications among other factors. Of these factors, diet 
formulation has the greatest impact ( $40 \%$ ) on pellet quality, followed by ingredient particle size (20 \%) (Reimer, 1992; Behnke, 1994).

\section{Corn Particle Size}

Corn is the main constituent of poultry diets in the United States. Although authors (Reimer, 1992; Behnke, 1994) have deemed ingredient particle size as one of the main factors affecting pellet quality, the literature is contradictory. Several studies have shown that changing ground corn particle size had no effect on pellet durability (Young, 1960; Reece et al., 1986; Koch, 1996), while others have reported that reducing corn particle size had modest improvements ( $<5$ percentage points) on pellet durability (Amerah et al., 2008; Chewning et al., 2012). Pellet quality has been thought to be adversely affected by increasing corn particle size due to decreased surface area, which allows for less contact points for binding within the pellet (Behnke, 2001). Svihus et al. (2004) suggested that using coarse cereal particles lead to reduced starch gelatinization, consequently reducing pellet quality. Therefore, commercial feed mills have traditionally used finely ground ingredients in pelleted diets.

Variations in corn particle size are known to influence broiler performance. In diets fed as mash, coarse particle corn improves weight gain and feed efficiency of broilers (Reece et al., 1985; Nir et al., 1994a; Nir et al., 1994b). However, improvement is less clear in broilers fed pelleted diets (Nir et al., 1994a). Lott et al. (1992) found that feeding broilers crumbled diets utilizing $1,170 \mu \mathrm{m}$ vs $710 \mu \mathrm{m}$ ground corn reduced weight gain up to $21 \mathrm{~d}$, but differences diminished at $42 \mathrm{~d}$. Ingredient particle size also has an impact on intestinal morphology and nutrient utilization. Nir et al. (1994b) reported that increasing geometric mean diameter (GMD) 
of ground corn, from 600 to $2,000 \mu \mathrm{m}$, was positively related to gizzard holding capacity and weight, while also reducing gizzard $\mathrm{pH}$. Other authors have demonstrated that increasing corn particle size in mash diets slows passage rate through the gastrointestinal (GI) tract (Lott, 1989), and increases nitrogen and lysine retention (Parsons et al., 2006). Svihus (2010) concluded that feeding diets of small particle grain, or diets lacking structural components, may lead to birds over-consuming feed, thereby increasing feed passage rate and consequently impairing nutrient utilization. Even so, many feed manufacturers believe that the pelleting process negates the benefits of coarse particle size grains.

\section{Zinc and NRC Recommendations}

Zinc (Zn) is a cofactor for over 240 endogenous enzymes including DNA and RNA synthesis, thermocyte development, and reproductive processes to name a few (O'Dell et al., 1958, Hudson et al., 2004; Manangi et al., 2012). The most apparent Zn deficiency symptom is decreased feed intake, followed by decreased growth performance (O'Dell et al., 1958). Collagen and keratin both require Zn for synthesis (Rossi et al., 2007; Saenmahayak et al., 2010). Therefore, $\mathrm{Zn}$ deficiencies can be conducive to weakened skin elasticity, lesions, and poor feathering. The NRC (1994) absolute requirement for $\mathrm{Zn}$ in broilers is $40 \mathrm{mg} / \mathrm{kg}$, regardless of source. The requirement is based solely on peer-reviewed articles prior to 1994, and is extrapolated from other avian species after three weeks of age (Leeson, 2005). Studies used to support the NRC requirements for trace minerals generally use purified or semi-purified diets, due to variability in grain content and poor knowledge of bioavailability (Leeson, 2005). Past research has shown that the $\mathrm{Zn}$ content of a typical corn-soybean meal based broiler diet can vary 
from 20 to $45 \mathrm{mg}$ per $\mathrm{kg}$ of feed (Wedekind et al., 1992; Leeson, 2005; Huang et al., 2007; Liu et al., 2013). Many poultry researchers believe that the NRC (1994) recommendations are no longer valid, and must be revisited. These factors being considered, coupled with low cost of inorganic trace minerals, commercial nutritionists allow a generous safety margin to ensure there are no deficiencies (Leeson, 2005).

Inorganic Zn supplements, as opposed to organic chelates, have traditionally been used in diet formulation due to low costs. However, organic $\mathrm{Zn}$ chelates have higher bioavailability than inorganic sources (Wedekind et al., 1992; Richards et al., 2010), subsequently reducing environmental impact via reduced manure loading of Zn (Leeson and Caston, 2008; Manangi et al., 2012). Richards et al. (2010) found that the relative bioavailability of a $\mathrm{Zn}$ amino acid chelate was $160 \%$ compared to $\mathrm{Zn}$ sulfate, based on tibia ash. Improvements in absorption can be attributed to decreased antagonistic reactions with dietary components within the GI tract, such as phytate, calcium, copper, and other trace minerals (O'Dell and Savage, 1960; O'Dell et al., 1964).

\section{Phytate Phosphorus and Phytase}

Myo-inositol 1,2,3,4,5,6-hexakis dihydrogen phosphate (IP6) exists in plants in an anionic form and is referred to as phytic acid or phytate. Phytate accounts for 50 to $80 \%$ of the phosphorus (P) in seed-based ingredients (Angel et al., 2002). Early reports suggested that phytate-P (PP) was essentially unavailable to poultry (Lowe et al., 1939; Kreiger et al., 1940), whereas more recent work has demonstrated that variable amounts of PP can be utilized by poultry (Waldroup et al., 1964; Nelson, 1976; Ballam et al., 1984). Variability in PP utilization 
is associated with the nutrient composition and physical form of feed (i.e. Ca, nPP, $\mathrm{D}_{3}$, particle size). Nevertheless, PP is poorly utilized by poultry in most scenarios (Erdman, 1979; Ravindran et al., 1994; Maenz, 2001; Angel et al., 2002). Poor utilization of PP by animals leads to increased diet costs due to the use of inorganic phosphates and environmental concerns associated with P manure loading. Phytate is a known anti-nutritional factor, affecting availability of minerals, dietary amino acids, and energy (Lonnerdal et al., 1999; Ravindran et al., 2000; Angel et al., 2002; Cowieson et al., 2006). Addition of exogenous phytase to diets has been shown to increase phytate-P digestibility and alleviate anti-nutritive effects in swine and poultry (Simons et al., 1990; Ravindran et al., 2000; Maenz, 2001; Cowieson et al., 2006). Phytases are traditionally produced in microbial expression systems and commercialized as coated, granular, or liquid products. The process of granulation improves handling properties and provides a water barrier, which likely improves enzyme retention post-pelleting. Granular enzymes are added to diets during mixing, as opposed to liquid products which are either added during mixing or post-pelleting within the oil or fat source.

\section{Mix Uniformity}

Proper dispersion of diet components within a mixer is often termed "mix uniformity". Mix uniformity is particularly important when drugs or low inclusion ingredients (i.e. enzymes) are added to diets. McCoy et al. (1994) demonstrated that increasing mix time, and subsequently increasing mix uniformity improved average daily gain, average daily feed intake, and gain:feed during the growing phase of broilers. A common measure of mix uniformity is mixer coefficient of variation $(\mathrm{CV})$, which is determined by selecting a marker within the diet and is considered 
adequate below $10 \%$ after 5 min of mixing. Pfost et al. (1966) listed several criteria for selecting a marker and are as follows: 1) do not select markers that do not effect animal performance; 2) select ingredients with similar physical properties (i.e. particle size and density); 3) do not utilize characteristics in which most or all ingredients carry (e.g., ash); 4) analytical assay variability must be less than mixer variation; 5) feed additives (drugs) can make good tracers, because degree of mixing is important from a legal and animal performance standpoint; 6) minerals can be good tracers because of density and particle size, but cost may be provocative. Clark et al. (2007) reported that CV decreased for several markers as mix time was increased from $30 \mathrm{sec}$ to $5 \mathrm{~min}$. However, only the crystalline amino acids, DL-methionine and L-Lysine $\mathrm{HCl}$, provided a CV value below $10 \%$. The authors also noted that crude protein was a poor marker and salt (chloride ion) concentration was inconsistent.

\section{Transgenic Seeds}

The idea of using transgenic seeds expressing phytase as a feed additive for poultry to improve phosphorus utilization was first introduced by Pen et al. (1993). The authors were able to transform a phytase enzyme derived from Aspergillus niger into tobacco seeds, and determined that the seeds maintained in vitro activity, even at a year post-harvest. Additionally, Pen et al. (1993) demonstrated that adding transgenic phytase tobacco seeds to broiler diets improved phosphorus utilization and weight gain in low-nPP diets and BW was similar when broiler diets included either transgenic tobacco seeds or a commercial A. niger phytase. Since this initial work, other authors have published similar results using transgenic soybeans and corn in broiler (Denbow et al., 1998; Nyannor and Adeola, 2008) and layer diets (Gao et al., 2013). 
Commercial phytases are normally produced in microbial expression systems. However, plants constitute a larger land mass than microbial expression systems, and may be an economically feasible production system. Corn, unlike tobacco seeds, is a bulk ingredient in the majority of U.S. poultry diets and, unlike soybeans, is not subject to thermal processing prior to diet batching.

Literature assessing the thermal stability of transgenic seeds expressing phytase is limited, particularly throughout the pelleting process. This is noteworthy because grains are typically mixer-added ingredients. Lucca et al. (2001) found that an A. niger phytase expressed in rice only maintained $8 \%$ of its original activity after boiling in water for $20 \mathrm{~min}$. BrinchPederson et al. (2006) reported that an Aspergillis fumigatus phytase expressed in the endosperm of wheat maintained $8 \%$ of its initial activity compared to the purified A. fumigatus phytase that maintained $59 \%$ activity, under similar conditions. These authors noted that the deposition of $A$. fumigatus in the endosperm of transgenic wheat appeared to impede refolding at temperatures above the enzyme's melting point.

\section{Biofuel and Microalgae}

Increased crude oil prices and depleting supplies of non-renewable fuel sources have led to the exploration of alternative fuel sources. Microalgae is a promising candidate due to its rapid growth cycle, rich oil content, and ability to grow in non-arable regions without potable water (Chisti, 2007). Unlike oil crops (e.g., corn and soybeans), microalgae is not a major constituent in animal or human diets. Currently, corn is the main feedstock used in the U.S. for ethanol production. In 2014, U.S. ethanol production exceeded 14,000 million gallons 
(Renewable Fuels Association, 2016). Though the by-product of ethanol, distiller's dried grains with solubles (DDGS), can be used in animal feed, its production has led to increased corn and animal feed prices. Chisti (2007) estimated that $50 \%$ of the US transport fuel needs could be met if 1-3 \% of US crop land produced algal biomass. As a co-product of algal biofuel production, a nutrient-rich dryed biomass remains and has potential to be used in animal rations. Microalgae has an amino acid profile comparable to soybean meal (Becker, 2007), and contains significant amounts of carbohydrates, polyunsaturated lipids, and minerals.

The use of full-fat algae from various sources has been explored as an ingredient for animal feed for several decades (Grau and Klein, 1957; Hintz and Heitman, 1967; Ross and Dominy, 1990; Evans et al., 2015). However, its use in commercial diets is limited due to economic constraints. Authors have reported no detriment to growth rate or feed efficiency when supplementing protein sources with Cholorella and Scenedesmus spp. up to $10 \%$ in growing-finishing pigs (Hintz and Heitman, 1967), and up to $12 \%$ replacement of skim milk and soybean meal with Spirulina maxima in weanling pigs (Février and Sève, 1975). The use of algae for biofuel is relatively new, and little research has assessed the use of oil-extracted algae biomass in animal diets.

\section{Turkey Genetics}

The growth rate and feed efficiency of modern turkey strains is quite astonishing. In a study comparing circa 2003 commercial turkeys to a 1966 random bred commercial strain, Havenstein et al. (2007) determined that the BW of 112-d-old toms and hens had increased by 
186 and $164 \mathrm{~g} / \mathrm{yr}$, respectively, while the time to reach market weight was halved. Additionally, Barbour and Lilburn (1995) found that commercial hens from 1992 were $28 \%$ larger at 20-wk than those studied by Moran et al. (1970), and Ferket (2001) stated that the time required for toms to reach a market weight of $16 \mathrm{~kg}$ decreased by $1.5 \mathrm{~d}$ per year from 1990 to 2001 . Improvements can be contributed, in part, to nutrition, management, and disease prevention, but are largely associated with genetic selection (Nestor et al., 1969; Sherwood, 1977; Havenstein et al., 2004). Along with advancements in performance, carcass characteristics and yields of turkeys have changed (Larsen et al., 1986; Lilburn and Nestor, 1991).

\section{Lysine}

Lysine is the second-limiting amino acid for poultry, and is the basis for formulating digestible amino acids in diets. The majority of lysine oxidation occurs via the lysine $\alpha$ ketoglutarate reductase (LKR) pathway (Blemings et al., 1994; Manangi et al., 2005). This is a two-step process in which lysine and $\alpha$-ketoglutarate are first converted to saccharopine by LKR, then saccharopine is converted to $\alpha$-amino-adipate semialdehyde and glutamate by saccharopine dehydrogenase (Manangi et al., 2005). Wang and Nesheim (1972) determined that genetic differences in lysine metabolism could be observed by LKR content in chicks. Wang et al. (1973) also suggested that lysine oxidation was dependent on the lysine pool in chicks fed low dietary lysine, but LKR was indicative of lysine oxidation when chicks were supplied sufficient or high levels of dietary lysine. Improvements in lysine efficiency would likely be associated with increased feed efficiency and muscle assembly. West et al. (2010) found that Hybrid strain toms had lower LKR activity (d 1-136) than Nicholas strain toms, and also had a lower feed 
conversion ratio (FCR) during this growth period. Therefore, it is plausible that FCR may be inversely related to LKR activity.

\section{References}

Amerah, A. M., V. Ravindran, R. G. Lentle, and D. G. Thomas. 2008. Influence of feed particle size on the performance, energy utilization, digestive tract development, and digesta parameters of broiler starters fed wheat- and corn-based diets. Poult. Sci. 87(11):2320-2328.

Angel, R., N. M. Tamim, T. J. Applegate, A. S. Dhandu, and L. E. Ellestad. 2002. Phytic acid chemistry: Influence on phytin-phosphorus availability and phytase efficacy. J. Appl. Poult. Res. 11:471-480.

Ballam, G. C., T. S. Nelson, and L. K. Kirby. 1984. Effect of fiber and phytate source and of calcium and phosphorus level on phytate hydrolysis in the chick. Poult. Sci. 63:333-338.

Barbour, G. W. and M. S. Lilburn. 1995. Characterization of carcass development from 14 to 145 days of age in turkey hens from two strains. Poult. Sci. 74:1650-1658.

Becker, E. W. 2007. Micro-algae as a source of protein. Biotechnol. Adv. 25:207-210.

Behnke, K. C. 1994. Factors affecting pellet quality. Maryland Nutr. Conf. Dept. of Poultry Science and Animal Science, College of Agriculture, University of Maryland, College Park.

Behnke, K. C. 1996. Feed manufacturing technology: current issues and challenges. Anim. Feed Sci. Technol. 62:49-57.

Behnke, K. C. 2001. Factors influencing pellet quality. Feed Technol. 5:19-22.

Blemings, K. P., T. D. Crenshaw, R. W. Swick, and N. J. Benevenga. 1994. Lysine- $\alpha-$ ketoglutarate reductase and saccharopine dehydrogenase are located only in the mitochondrial matrix in rat liver. J. Nutr. 124:1215-1221.

Brinch-Pederson, H., F. Hatzach, E. Stöger, E. Arcalis, K. Pontopidan, and P. B. Holm. 2006. Heat-stable phytases in transgenic wheat (Triticum aestivum L.): Deposition pattern, thermostability, and phytate hydrolysis. J. Agric. Food Chem. 54:4624-4632. 
Buchanan, N. P. and J. S. Moritz. 2009. Main effects and interactions of varying formulation protein, fiber, and moisture on feed manufacture and pellet quality. J. Appl. Poult. Res. 18(2):274-283.

Chewning, C. G., C. R. Stark, and J. Brake. 2012. Effects of particle size and feed form on broiler performance. J. Appl. Poult. Res. 21:830-837.

Chisti, Y. 2007. Biodiesel from microalgae. Biotechnol. Adv. 25:294-306.

Clark, P. M., K. C. Behnke, and D. R. Poole. 2007. Effects of marker selection and mix time on the coefficient of variation (mix uniformity) of broiler feed. J. Appl. Poult. Res. 16:464-470.

Corey, A. M., K. G. S. Wamsley, T. S. Winowiski, and J. S. Moritz. 2014. Effects of calcium lignosulfonate, mixer-added fat, and feed form on feed manufacture and broiler performance. J. Appl. Poult. Res. 23:418-428.

Cowieson, A. J., T. Acamovic, and M. R. Bedford. 2006. Phytic acid and phytase: Implications for protein utilization by poultry. Poult. Sci. 85:878-885.

Cutlip, S. E., J. M. Hott, N. P. Buchanan, A. L. Rack, J. D. Latshaw, and J. S. Moritz. 2008. The effect of steam-conditioning practices and growing broiler nutritional value. J. Appl. Poult. Res. 17:249-261.

Denbow, D. M., E. A. Grabau, G. H. Lacy, E. T. Kornegay, D. R. Russell, and P. F. Umbeck. 1998. Soybeans transformed with a fungal phytase gene improve phosphorus availability for broilers. Poult. Sci. 77:878-881.

Erdman, J. W. 1979. Oilseed phytates: Nutritional implications. J. Am. Oil Chem. Soc. 56(8):736-741.

Evans, A. M., D. L. Smith, and J. S. Moritz. 2015. Effects of algae incorporation into broiler starter diet formulations on nutrient digestibility and 3 to $21 \mathrm{~d}$ bird performance. J. Appl. Poult. Res. 24:206-214.

Ferket, P. R. 2001. Turkey growth statistics: Growth rate continues to climb. Poult. USA. 2:4050.

Février, C., and B. Sève. 1975. Incorporation of a spiruline (Spirulina maxima) in swine food. Ann. Nutr. Aliment. 29:625-650.

Gao, C. Q., C. Ji, L. H. Zhao, J. Y. Zhang, and Q. G. Ma. 2013. Phytase transgenic corn in nutrition of laying hens: Residual phytase activity and phytate phosphorus content in the gastrointestinal tract. Poult. Sci. 92:2923-2929.

Grau, C. R. and N. W. Klein. 1957. Sewage-grown algae as a feedstuff for chicks. Poult. Sci. 36:1046-1051. 
Havenstein, G. B., P. R. Ferket, J. L. Grimes, M. A. Qureshi, and K. E. Nestor. 2004. Performance of 1966 vs. 2003-type turkeys when fed representative 1966 and 2003 turkey diets. Proc. World's Poult. Congr., Istanbul, Turkey. WPSA, Izmir, Turkey.

Havenstein, G. B., P. R. Ferket, J. L. Grimes, M. A. Qureshi, and K. E. Nestor. 2007. Comparison of the performance of 1966- versus 2003-type turkeys when fed representative 1966 and 2003 turkey diets: Growth rate, livability, and feed conversion. Poult. Sci. 86:232240.

Hintz, H. F., and H. Heitman. 1967. Sewage-grown algae as a protein supplement for swine. Anim. Prod. 9:135-140.

Huang, Y. L., L. Lu, X. G. Luo, and B. Liu. 2007. An optimal dietary zinc level of broiler chicks fed a corn-soybean meal diet. Poult. Sci. 86:2582-2589.

Hudson, B. P., W. A. Dozier, J. L. Wilson, J. E. Sander, and T. L. Ward. 2004. Reproductive performance and immune status of caged broiler breeder hens provided diets supplemented with either inorganic or organic sources of zinc from hatching to 65 wk of age. J. Appl. Poult. Res. 13:349-359.

Jensen, L. S., L. H. Merill, C. V. Reddy, and J. McGinnis. 1962. Observations on eating patterns and rate of food passage of birds fed pelleted and unpelleted diets. Poult. Sci. 41:1414-1419.

Koch, K. 1996. Hammermills and rollermills. MF-2048 Feed Manufacturing, Department of Grain Science and Industry, Kansas State University. Pg. 8.

Kreiger, C. H., R. Bunkfeldt, and H. Steenbock. 1940. Cereals and rickets. X. The availability of phytic acid phosphorus. J. Nutr. 20:7-14.

Larsen, J. E., R. L. Adams, I. C. Peng, and W. J. Stadelman. 1986. Growth, feed conversions, and yields of turkey parts of three strains of hen turkeys as influenced by age. Poult. Sci. 65:2076-2081.

Leeson, S. 2005. Trace mineral requirements of poultry - validity of the NRC requirements. Pages 107-118 in Redefining Mineral Nutrition. J. A. Taylor-Pickard and L.A. Tucker, ed. Nottingham Univ. Press, Nottingham, UK.

Leeson S., and L. Caston. 2008. Using minimal supplements of trace minerals as a method of reducing trace mineral content of poultry manure. Anim. Feed Sci. Technol. 142:339-347.

Lilburn, M. S. and K. E. Nestor. 1991. Body weight and carcass development in different lines of turkeys. Poult. Sci. 70:2223-2231. 
Lilly, K.G.S., C. K. Gehring, K. R. Beaman, P. J. Turk, M. Sperow, and J. S. Moritz. 2011. Examining the relationship between pellet quality, broiler performance, and bird sex. J.Appl. Poult. Res. 20: 231-239.

Liu, S. B., S. F. Li, L. Lu, J. Xie, L. Y. Zhang, R. L. Wang, and X. G. Luo. 2013. The effectiveness of zinc proteinate for chicks fed a conventional corn-soybean diet. J. Appl. Poult. Res. 22:396-403.

Loar, R. E. II, K. G. S. Wamsley, A. Evans, J. S. Moritz, and A. Corzo. 2014. Effects of varying conditioning temperature and mixer-added fat on feed manufacturing efficiency, 28- to 42day broiler performance, early skeletal effect, and true amino acid digestibility. J. Appl. Poult. Res. 23:444-455.

Lonnerdal, B., L. Jayawickramaand, and E. L. Lien. 1999. Effect of reducing the phytate content and of partially hydrolyzing the protein in soy formula on zinc and copper absorption and status in infant rhesus monkeys and rat pups. Am. J. Clin. Nutr. 69:490-496.

Lott, B. D., 1989. The Effect of Corn Particle Size on Water Consumption and Broiler Performance. Ph.D. dissertation. Mississippi State University, Mississippi State, MS.

Lott, B. D., E. J. Day, J. W. Deaton, and J. D. May. 1992. The effect of temperature, dietary energy level, and corn particle size on broiler performance. Poult. Sci. 71:618-624.

Lowe, J. T., H. Steenbock, and C. H. Kreiger. 1939. Cereals and rickets. XII. The availability of phytin-P to the chicks. Poult. Sci. 18:40-41.

Lucca, P., R. Hurrell, and I. Potrykus. 2001. Genetic engineering approaches to improve the bioavailability and the level of iron in rice grains. Theor. Appl. Genet. 102:392-397.

Maenz, D. D. 2001. Enzymatic characteristics of phytases as they relate to their use in animal feeds. Pages 61-83 in Enzymes in Farm Animal Nutrition. M. R. Bedford and G. G. Partridge, ed. CAB International, Wallingford, UK.

Manangi, M. K., S. F. A. Hoewing, J. G. Engels, A. D. Higgins, J. Killefer, M. E. Wilson, and K. P. Blemings. 2005. Lysine $\alpha$-ketoglutarate reductase and lysine oxidation are distributed in the extrahepatic tissues of chickens. J. Nutr. 135:81-85.

Manangi, M. K., M. Vasquez-Añon, J. D. Richards, S. Carter, R. E. Buresh, and K. D. Christensen. 2012. Impact of feeding lower levels of chelated trace minerals versus industry levels of inorganic trace minerals on broiler performance, yield, footpad health, and litter mineral concentration. J. Appl. Poult. Res. 21:881-890.

McCoy, R. A., K. C. Behnke, J. D. Hancock, and R. R. McEllhiney. 1994. Effect of mixing uniformity on broiler chick performance. Poult. Sci. 73:443-451. 
Moran, E. T., Jr., H. L. Orr, and E. Larmond. 1970. Production efficiency, grades and yields with the Large White turkey as related to sex and age. Poult. Sci. 49:475-493.

National Research Council, (1994). Nutrient Requirements of Poultry. 9th Rev. Ed. NAS-NRC, Washington, D.C.

Nelson, T. S. 1976. The hydrolysis of phytate phosphorus by chicks and laying hens. Poult. Sci. 55:2262-2264.

Nestor, K. E., M. G. McCartney, and N. Bachev. 1969. Relative contributions of genetics and environment to turkey improvement. Poult. Sci. 43:739-744.

Nir, I., G. Shefet, and Y. Aaroni. 1994a. Effect of particle size on performance. 1. Corn. Poult. Sci. 73: 45-49.

Nir, I., R. Hillel, G. Shefet, and Z. Nitsan. 1994b. Effect of grain particle size on performance 2. Grain texture interactions. Poult. Sci. 73:781-791.

Nyannor, E. K. D. and O. Adeola. 2008. Corn expressing Escherichia Coli-derived phytase gene: Comparitive study in broiler chicks. Poult. Sci. 87:2015-2022.

O’Dell, B. L., P. M. Newberne, and J. E. Savage. 1958. Significance of dietary zinc for the growing chicken. J. Nutr. 63:503-518.

O’Dell, B. L., and J. E. Savage. 1960. Effect of phytic acid on zinc availability. Proc. Soc. Exp. Biol. Med. 103:304-306.

O’Dell, B. L., J. M. Yohe, and J. E. Savage. 1964. Zinc availability in the chick as affected by phytate, calcium, and ethylenediaminetetraacetate. Poult. Sci. 43:415-419.

Parsons, A. S., N. P. Buchanon, K. P. Blemings, M. E. Wilson, and J. S. Moritz. 2006. Effect of corn particle size and pellet texture on broiler performance in the growing phase. J. Appl. Poult. Res. 15:245-255.

Pen, J., T. C. Verwoerd, P. A. van Paridon, R. F. Beudeker, P. J. M. van den Elzen, K. Geerse, J. D. van der Klis, H. A. J. Versteegh, A. J. J. van Ooyen, and A. Hoekema. 1993. Phytasecontaining transgenic seeds as a novel feed additive for improved phosphorus utilization. Nat. Biotechnol. 11:811-814.

Pfost, H. B., C. Deyoe, C. Stevens, and E. Morgan. 1966. Testing feed mixtures, mixers, and related equipment. Feedstuffs. 38:32-46.

Ravindran, V., G. Ravindran, and S. Sivalogan. 1994. Total and phytate phosphorus contents of various foods and feedstuffs of plant origin. Food Chem. 50:133-136. 
Ravindran, V., S. Cabahug, G. Ravindran, P. H. Selle, and W. L. Bryden. 2000. Response of broiler chickens to microbial phytase supplementation as influenced by dietary phytic acid and non-phytate phosphorus levels. II. Effects on apparent metabolisable energy, nutrient digestibility and nutrient retention. Br. Poult. Sci. 41:2, 193-200.

Reece, F. N., B. D. Lott, and J. W. Deaton. 1985. The effects of feed form, grinding method, energy level, and gender on broiler performance in a moderate (21 C) environment. Poult. Sci. 64:1834-1839.

Reece, F. N., B. D. Lott, and J. W. Deaton. 1986. The effects of hammermill screen size on ground corn particle size, pellet durability, and broiler performance. Poult. Sci. 65:12571261.

Reimer, L. 1992. Conditioning. In: Proc. Northern Crops Institute Feed Mill Management and Feed Manufacturing Technol. Short Course. Page 7. California Pellet Mill Co., Crawfordsville, IN.

Renewable Fuels Association. January, 2016.

Richards, J. D., P. Fisher, T. D. Wineman, C. A. Atwell, and K. J. Wedekind. 2010. Estimation of the $\mathrm{Zn}$ bioavailability of a $\mathrm{Zn}$ chelate relative to $\mathrm{Zn}$ sulphate based on the tibia $\mathrm{Zn}$ and small intestinal metallothionein expression. Pages 2-3 in Int. Poult. Sci. Forum, Atlanta, GA Southern Poult. Sci. Soc. (Abstr) http://www.poultscience.org/abstracts.asp.

Ross, E. and W. Dominy. 1990. The nutritional value of dehydrated, blue-green algae (Spirulina plantensis) for poultry. Poult. Sci. 69:794-800.

Rossi, P., F. Rutz, M. A. Anciuti, J. L. Rech, and N. H. F. Zauk. 2007. Influence of graded levels of organic zinc on growth performance and carcass traits of broilers. J. Appl. Poult. Res. $16: 219-225$.

Saenmahayak, B., S. F. Bilgili, J. B. Hess, and M. Singh. 2010. Live and processing performance of broiler chickens fed diets supplemented with complexed zinc. J. Appl. Poult. Res. 19:334-340.

Sherwood, D. H. 1977. Modern broiler feeds and strains: What two decades of improvement have done. Feedstuffs 49:70.

Simons, P. C. M., H. A. J. Versteegh, A. W. Jongbloed, P. A. Kemme, P. Slump, K. D. Bos, M. G. E. Wolters, R. F. Beudeker, and G. J. Verschoor. 1990. Improvement of phosphorus availability by microbial phytase in broilers and pigs. Br. J. Nutr. 64:525-540.

Svihus, B., K. H. Klovstad, V. Perez, O. Zimonja, S. Sahlstrom, and R. B. Schuller. 2004. Physical and nutritional effects of pelleting of broiler chicken diets made from wheat ground to different coarseness by the use of roller mill and hammer mill. Anim. Feed Sci. Technol. 117:281-293. 
Svihus, B. 2010. Diet composition and processing adjustments to cover the bird's need for structural components. Pages 99-107 in Proc. 8th Mid-Atlantic Nutr. Conf., Timonium, MD. Univ. Maryland, College Park.

Waldroup, P. W., C. B. Ammerman, and R. H. Harms. 1964. The availability of phytic acid phosphorus for chicks. 3. Effect of calcium and vitamin D3 levels on the utilization of calcium phytate. Poult. Sci. 43:926-931.

Wang, S-H. and M. C. Nesheim. 1972. Degradation of lysine in chicks. J. Nutr. 102:583.

Wang, S-H., L. O. Crosby, and M. C. Nesheim. 1973. The effect of dietary excesses of lysine and arginine on the degradation of lysine by chicks. J. Nutr. 103:384.

Wedekind, K. J., A. E. Hortin, and D. H. Baker. 1992. Methodology for assessing zinc bioavailability: efficacy estimates for zinc-methionine, zinc sulfate, and zinc oxide. J. Anim. Sci. 70:178-187.

West, B. N., K. G. S. Lilly, K. R. Beaman, L. K. Shires, S. A. Loop, and J. S. Moritz. 2010. The effects of strain and dietary phosphorus level on large tom turkey performance. Poult. Sci. Vol. 89 (E - Suppl. 1): W267.

Wondra, K. J., J. D. Hancock, K. C. Behnke, and C. R. Stark. 1995. Effects of mill type and particle size uniformity on growth performance, nutrient digestibility, and stomach morphology in finishing pigs. J. Anim. Sci. 73:2564-2573.

Young, L. R. 1960. Mechanical durability of feed pellets. Master's thesis, Kansas State University, Manhattan, KS. 


\title{
CHAPTER 2
}

Effect of zinc supplementation source and corn particle size on 40-d broiler performance

\author{
K. L. Foltz, B.G. Glover, ${ }^{*}$ and J. S. Moritz ${ }^{*} 1$
}

"Division of Animal and Nutritional Sciences, West Virginia University, Morgantown, WV 26506

Primary Audience: Nutritionists, Feed mill managers, Researchers

${ }^{1}$ Corresponding author: jsmoritz@mail.wvu.edu 


\section{SUMMARY}

Zinc $(\mathrm{Zn})$ supplementation source and particle size of feed ingredients are two factors that can affect poultry performance and should be considered for proper feeding of poultry. The objective of the current study was to assess the effects of $\mathrm{Zn}$ supplementation source and corn particle size on broiler performance, breast yield, and tibia $\mathrm{Zn}$ concentration. Treatments were arranged in a 5 × 2 factorial randomized complete block design with the main effects $\mathrm{Zn}$ supplement source and corn particle size (550 micron vs 1,050 micron). Zinc treatments included a basal diet (no added $\mathrm{Zn}$ ), $80 \mathrm{mg} / \mathrm{kg} \mathrm{Zn}$ sulfate, and three diets with $40 \mathrm{mg} / \mathrm{kg} \mathrm{Zn}$ sulfate $+40 \mathrm{mg} / \mathrm{kg}$ of varying $\mathrm{Zn}$ amino acid chelates. Diets varied only in corn particle size and Zn supplementation source, while pellet durability differed by 3 percentage points favoring small particle corn diets. A total of eight replications per dietary treatment were fed to broilers from d 1-40. A Zn supplement $x$ corn particle size interaction was observed for ending bird weight and LWG $(P<0.05)$ demonstrating that feeding small particle corn produced larger broilers except when supplemental $\mathrm{Zn}$ was not included. Broilers fed small particle corn or diets supplemented with $\mathrm{Zn}$ consumed the most feed $(P<0.05)$. However, FCR was decreased $(P<0.05)$ by 0.019 for broilers fed large particle corn diets. Tibia $\mathrm{Zn}$ concentration was significantly higher $(P<$ 0.0001) for Zn supplemented diets, but no other treatment effects were observed. In conclusion, Zn supplement source had little effect on broiler performance; however Zn supplementation per se optimized performance. Small particle corn increased FI and LWG, but was inferior in regards to FCR, suggesting that large particle corn may be beneficial to performance, particularly in the finisher phase (d 23-40).

Key words: zinc source, particle size, broiler performance, NRC, tibia ash 


\section{DESCRIPTION OF PROBLEM}

Zinc $(\mathbf{Z n})$ is a cofactor for over 240 endogenous enzymes including DNA and RNA synthesis, thermocyte development, and reproductive processes [1-3]. Zinc deficiencies decrease feed intake, and consequently lower growth performance [1]. Collagen and keratin both require $\mathrm{Zn}$ for synthesis [4-5]. Therefore, $\mathrm{Zn}$ deficiencies also result in weakened skin elasticity, lesions, and poor feathering. The NRC (1994) [6] absolute requirement for $\mathrm{Zn}$ in broilers is $40 \mathrm{mg} / \mathrm{kg}$. The requirement is based solely on peer-reviewed articles prior to 1994, and is extrapolated from other avian species after three weeks of age [7]. Studies used to support the NRC requirements for trace minerals generally use purified or semi-purified diets, due to variability in grain content and poor knowledge of bioavailability [7]. These factors being considered and low cost of inorganic trace minerals, commercial nutritionists allow a generous safety margin to ensure there are no deficiencies [7].

Inorganic $\mathrm{Zn}$ supplements have traditionally been used in diet formulation due to low costs. However, research has shown that organic $\mathrm{Zn}$ chelates have higher bioavailability than inorganic sources [8-9], subsequently reducing environmental impact via reduced manure loading of $\mathrm{Zn}[3,10]$. Richards et al. [9] found that the relative bioavailability of a $\mathrm{Zn}$ amino acid chelate was $160 \%$ compared to $\mathrm{Zn}$ sulfate, based on tibia ash. Improvements in absorption can be attributed to decreased antagonistic reactions with dietary components within the gastrointestinal (GI) tract, such as phytate, calcium, copper, and other trace minerals [11-12].

Corn particle size is also known to influence broiler performance. Research shows that feeding coarse particle corn, in mash diets, to broilers improves weight gain and feed efficiency [13-15]. However, this is less clear in broilers fed pelleted diets [14]. Nir et al. [16] reported that increasing geometric mean diameter (GMD) of ground corn, from 600 to $2000 \mu \mathrm{m}$, was 
positively related to gizzard holding capacity and weight, while being inversely related to gizzard $\mathrm{pH}$. The passage rate of diets with large particle corn is slower [17] and increases nitrogen and lysine retention [18]. Pellet quality has been shown to be adversely affected by increasing corn particle size due to decreased surface area which allows for less contact points for binding within the pellet [19]. Past research shows that increasing pellet quality is beneficial for broiler performance [20], therefore most commercial poultry diets utilize diets containing grain of relatively small particle size [21]. Svihus [21] stated that using small particle grain, or diets lacking structural components, also leads to suboptimal performance in regard to nutrient utilization.

The objectives of the current study were to: 1) revisit the effect of corn particle size on pellet quality and 2) determine the effect of partial replacement of inorganic $\mathrm{Zn}$ (Zn sulfate) with various organic $\mathrm{Zn}$ chelates and 3) its interaction with corn particle size in regard to performance, breast yield, and tibia ash. 


\section{MATERIALS AND METHODS}

\section{Experimental Design}

Treatments consisted of a $5 \times 2$ factorial arranged in a randomized complete block design with main effects $\mathrm{Zn}$ supplement source and corn particle size. The experimental unit was one pen of 23 Hubbard x Cobb straight-run broilers. Blocking criterion was pen location within the room. Diets consisted of either small or large $(550$ or $1,050 \mu \mathrm{m})$ GMD ground corn and the following five supplemental Zn sources: no supplemental $\mathrm{Zn}, 80 \mathrm{mg} / \mathrm{kg} \mathrm{Zn}$ sulfate $\left(\mathbf{Z n S O}_{\mathbf{4}}\right), 40$ $\mathrm{mg} / \mathrm{kg}$ Zn sulfate $+40 \mathrm{mg} / \mathrm{kg}$ Zn-glycine amino acid (AA) chelate (Zn-gly), 40 mg/kg Zn sulfate + 40 mg/kg Zn-AA complex (Zn-AA), or 40 mg/kg Zn sulfate + 40 mg/kg Zn bis(-2-hydroxy-4methylthio)butanoic acid (Zn-HMTBA). Hence, there were a total of 10 treatments.

\section{Feed Manufacture}

All feed was manufactured at the West Virginia University pilot feed mill. Basal diets were formulated on a digestible AA basis to meet or exceed NRC (1994) [6] recommendations and average nutrient usage concentrations in the United States [22], with the exception of Zn. The vitamin/mineral premix utilized at a $0.25 \%$ inclusion resulted in $0.0068 \mathrm{mg} \mathrm{Zn} / \mathrm{kg}$ of the complete diet (Table 1). Prior to feed manufacture, whole kernel corn was ground via hammermill to obtain targeted particle size. The small particle corn was manufactured by grinding two times through a $2.0 \mathrm{~mm}$ screen opening. To obtain the large particle treatment, corn was first ground through a $10.0 \mathrm{~mm}$ screen opening and then reground with no screen. Corn particle size was analyzed by processing a $100 \mathrm{~g}$ representative sample through a RO-TAP RX-29 [23]. Geometric mean diameter and geometric standard deviation (GSD) of corn used for each growth phase is shown in Table 2. 
Basal diets with the corresponding corn particle size were batched and divided into five equal allotments. The appropriate $\mathrm{Zn}$ supplement was then added to each allotment and remixed prior to pelleting. Sand was used as filler in place of $\mathrm{Zn}$ supplements for the no supplemental $\mathrm{Zn}$ treatment. All diets were conditioned at $82{ }^{\circ} \mathrm{C}$ for $\sim 10$ seconds and extruded through a $4.8 \mathrm{x}$ $38.1 \mathrm{~mm}$ pellet die using a 40-HP California pellet mill [24]. Starter (d 1-10) and grower (d 1122) diets were fed as a crumble and the finisher (d 23-40) diets were fed as intact pellets. Dietary treatments varied only in corn particle size and $\mathrm{Zn}$ supplement source. Cooled pellet samples were collected for pellet durability analysis. Pellet durability was determined by a New Holmen Pellet tester [25]. Descriptive feed manufacture and pellet durability data are shown in Table 2.

\section{Birds and Housing}

A total of 1,840 Hubbard x Cobb 500 straight-run broiler chicks were obtained from a commercial hatchery [26] and were vaccinated for Marek's and New Castle disease. Chicks were weighed and allocated equally among 80 floor pens $(0.69 \times 2.44 \mathrm{~m})$ with 23 chicks per pen. Each treatment (10 total) was replicated eight times corresponding to each block. Litter in floor pens was built-up from one previous flock. Feed and water access were provided ad libitum with one feed pan adapted to a hopper and two nipples per pen. Temperature was set to $32.8{ }^{\circ} \mathrm{C}$ on $\mathrm{d}$ 1 and decreased weekly by $2.8^{\circ} \mathrm{C}$. Continual lighting was provided d 1-3, 23L:1D from d 4-7, 20L:4D from d 8-24, and 23L:1D from d 25-40. Ventilation was provided as needed to supply fresh air and control temperature and ammonia levels. Mortality and temperature were recorded daily. All protocols were in accordance with the West Virginia University Animal Care and Usage Committee. 


\section{Data Collection}

Performance data was collected at the end of each growth phase (d 10, 22, and 40). Lighting and feed access were removed 8 hours prior to collection. Feed disappearance and ending bird weight, on a pen basis, were recorded and adjusted based on the number of birds per pen to determine feed intake per bird (FI), live weight gain per bird (LWG), and mortality corrected feed conversion ratio (FCR). Additionally, mortality was recorded as a percentage of starting bird number.

On d 40, three birds per pen were randomly selected and euthanized via cervical dislocation for hot breast yield analysis. Boneless, skinless breast tissue was removed and yield was recorded based on individual live bird weight. The left tibia of each bird was excised for analyzing tibia ash and tibia $\mathrm{Zn}$ concentration. Soft tissue was removed and tibiae were dried to constant weight. Tibiae (pooled for each pen) were fat extracted using a soxhlet apparatus in petroleum ether for 16 hours and ashed in a muffled furnace at $600{ }^{\circ} \mathrm{C}$ for 18 hours. Ash content was analyzed for $\mathrm{Zn}$ concentration via inductively coupled plasma mass spectrometry at a commercial laboratory [27].

\section{Statistical Analysis}

Variables were analyzed in a 5 (Zn supplement source) x 2 (corn particle size) factorial in a randomized complete block design with fixed effects. The experimental unit was a pen of 23 straight-run broilers. Analyses were completed using the PROC GLM procedure of Statistical Analysis System (SAS) [28] for one-way ANOVA with $\alpha$ set at 0.05. When the F test was significant, means were separated using Fisher's LSD post hoc comparison. 


\section{RESULTS AND DISCUSSION}

Marginal or no improvement in pellet durability was apparent when using $550 \mu \mathrm{m}$ corn compared to $1,050 \mu \mathrm{m}$ corn ( 86.2 vs 82.3 for starter; 87.0 vs 87.3 for grower; 83.6 vs 80.7 for finisher, respectively) (Table 2). Amerah et al. [29] reported that decreasing corn particle size from 530 to $300 \mu \mathrm{m}$ improved New Holmen pellet durability (93.8 \% vs $91.8 \%$ ). Chewning et al. [30] reported similar results (3-4 \% difference) when comparing 300 vs $600 \mu \mathrm{m}$ corn. Past research shows that such a modest improvement in pellet quality would not be expected to affect broiler performance [31].

A Zn supplement source $x$ corn particle size interaction was observed for overall (d 1-40) FI per bird, ending body weight (EBW), and LWG per bird $(P<0.01)$. Feed intake per bird was increased when birds were provided small particle corn, with the exception of the diet without supplemental $\mathrm{Zn}$ (Table 3). Supplementing $\mathrm{Zn}$ to small particle corn treatments improved EBW/bird by $\sim 170 \mathrm{~g}$, but this same effect was not observed for large particle corn diets. All treatments had similar EBW except for the small corn particle basal and large particle Zn-AA treatments (Table 3). During the overall growth period, FCR was decreased by 0.019 in broilers fed diets utilizing large particle corn $(P<0.01)$. However, there were no differences among $\mathrm{Zn}$ supplement sources $(P=0.50)$. It is important to note that $\mathrm{Zn}$ concentration in the diet without supplemental Zn was between 31.8-44.5 mg/kg (Table 1), which comes only from grains (cornsoybean) in formulation. Therefore, NRC (1994) requirements are already met in the starter and grower diets before supplementing $\mathrm{Zn}$. Research has shown that $\mathrm{Zn}$ content in a typical cornsoybean broiler starter diet can vary from $20-45 \mathrm{mg} / \mathrm{kg}[7,8,32,33]$. During the overall growth period, broilers fed diets with large particle corn and no supplemental Zn had similar LWG compared to diets with supplemental Zn, without compromising FCR. These data suggest that 
within the current study, NRC (1994) requirements for Zn may be sufficient for adequate broiler performance when the corn particle size within crumbled or pelleted diets is $1,050 \mu \mathrm{m}$. Svihus [21] reported that broilers fed diets lacking structural components may over-consume feed, leading to impaired nutrient utilization due to increased feed passage rate.

Examining phase specific growth performance, LWG/bird was increased by 4.0 and $18 \mathrm{~g}$ $(P<0.01)$ when diets contained small particle corn for starter and grower phases, respectively (Table 4). These data correspond with increases in FI/bird, $9.0 \mathrm{~g}$ for starter and $24 \mathrm{~g}$ for grower $(P<0.001)$, while there were no significant differences in FCR $(P=0.36 ; P=0.84)$. Hence, reducing corn particle size from 1,050 to $550 \mu \mathrm{m}$ may be beneficial for the first $22 \mathrm{~d}$ post hatch per se. Nir et al. [15] suggested that the optimal corn particle size for juvenile broiler chicks was between 700-900 $\mu \mathrm{m}$ in mash diets. Additionally, supplementation of $\mathrm{Zn}$ at $80 \mathrm{mg} / \mathrm{kg}$ (regardless of source) increased FI/bird and LWG/bird $(P<0.05)$ during starter and grower phases without compromising FCR (Table 4). Interestingly, the most pronounced effect in the finisher phase was a 0.035 reduction in FCR $(P<0.001)$ in favor of large particle corn diets. Birds fed the small particle corn diet without supplemental $\mathrm{Zn}$ had reduced FI/bird compared to all other small particle corn treatments in the finisher phase (Table 4). These data are in agreement with Lott et al. [34] that crumbled diets utilizing 1,170 vs $710 \mu \mathrm{m}$ reduced weight gain up to $21 \mathrm{~d}$, but diminished at $42 \mathrm{~d}$.

Hot breast tissue samples taken on d 40 demonstrated a $22.9 \mathrm{~g}$ increase in breast weight $(P<0.05)$ and $0.5 \%$ increase in yield $(P<0.05)$ for broilers fed small particle corn diets compared to broilers fed large particle corn diets (Table 5). Past literature has suggested that increasing structural components in a diet past a critical point adversely effects muscle accretion due to expenditures in gizzard growth and function [21]. Due to feed conversion benefits within 
the finisher phase and overall growth period, bone mineralization and $\mathrm{Zn}$ concentration analyses were only completed for large particle corn treatments and the small particle corn diet without supplemental Zn (Table 5). Bone mineralization was not affected by $\mathrm{Zn}$ supplement source $(P>$ 0.05). Conversely, tibia Zn concentration was increased $(P<0.0001)$ in treatments with supplemental Zn compared to treatments without supplemental Zn.

\section{CONCLUSIONS AND APPLICATIONS}

1) Supplementing corn-soybean based diets with $80 \mathrm{mg} / \mathrm{kg} \mathrm{Zn} \mathrm{(} \mathrm{100} \mathrm{mg/kg} \mathrm{total)} \mathrm{improved}$ broiler performance (FI and LWG) during starter and grower phases, suggesting NRC (1994) $\mathrm{Zn}$ requirements may not be adequate for juvenile chicks within the parameters of this study.

2) Partially replacing $\mathrm{ZnSO} 4$ with organic $\mathrm{Zn}$ chelates had no effect on broiler performance parameters, when supplemented at $80 \mathrm{mg} / \mathrm{kg}$.

3) Broilers fed large particle corn diets without supplemental Zn ( 40 mg/kg actual) during the finisher phase, and overall growth phase, grew similarly compared to diets with 80 $\mathrm{mg} / \mathrm{kg}$ supplemental Zn ( 100 mg/kg actual).

4) During the finisher (d 23-40) and overall growth periods (d 1-40), FCR was decreased when broilers were fed pellets with $1,050 \mu \mathrm{m}$ ground corn.

5) Reducing corn particle size from $1,050 \mu \mathrm{m}$ to $550 \mu \mathrm{m}$ in crumbles increased Hubbard $\mathrm{x}$ Cobb 500 broiler FI and LWG from d 1-22, without affecting FCR. 


\section{REFERENCES AND NOTES}

1. O’Dell, B. L., P. M. Newberne, and J. E. Savage. 1958. Significance of dietary zinc for the growing chicken. J. Nutr. 63:503-518.

2. Hudson, B. P., W. A. Dozier, J. L. Wilson, J. E. Sander, and T. L. Ward. 2004. Reproductive performance and immune status of caged broiler breeder hens provided diets supplemented with either inorganic or organic sources of zinc from hatching to 65 wk of age. J. Appl. Poult. Res. 13:349-359.

3. Manangi, M. K., M. Vasquez-Añon, J. D. Richards, S. Carter, R. E. Buresh, and K. D. Christensen. 2012. Impact of feeding lower levels of chelated trace minerals versus industry levels of inorganic trace minerals on broiler performance, yield, footpad health, and litter mineral concentration. J. Appl. Poult. Res. 21:881-890.

4. Saenmahayak, B., S. F. Bilgili, J. B. Hess, and M. Singh. 2010. Live and processing performance of broiler chickens fed diets supplemented with complexed zinc. J. Appl. Poult. Res. 19:334-340.

5. Rossi, P., F. Rutz, M. A. Anciuti, J. L. Rech, and N. H. F. Zauk. 2007. Influence of graded levels of organic zinc on growth performance and carcass traits of broilers. J. Appl. Poult. Res. 16:219-225.

6. National Research Council, (1994). Nutrient Requirements of Poultry. $9^{\text {th }}$ Rev. Ed. NASNRC, Washington, D.C.

7. Leeson, S. 2005. Trace mineral requirements of poultry - validity of the NRC requirements. Pages 107-118 in Redefining Mineral Nutrition. J. A. Taylor-Pickard and L.A. Tucker, ed. Nottingham Univ. Press, Nottingham, UK.

8. Wedekind, K. J., A. E. Hortin, and D. H. Baker. 1992. Methodology for assessing zinc bioavailability: efficacy estimates for zinc-methionine, zinc sulfate, and zinc oxide. J. Anim. Sci. 70:178-187.

9. Richards, J. D., P. Fisher, T. D. Wineman, C. A. Atwell, and K. J. Wedekind. 2010. Estimation of the $\mathrm{Zn}$ bioavailability of a $\mathrm{Zn}$ chelate relative to $\mathrm{Zn}$ sulphate based on the tibia $\mathrm{Zn}$ and small intestinal metallothionein expression. Pages 2-3 in Int. Poult. Sci. Forum, Atlanta, GA Southern Poult. Sci. Soc. (Abstr) http://www.poultscience.org/abstracts.asp. 
10. Leeson S., and L. Caston. 2008. Using minimal supplements of trace minerals as a method of reducing trace mineral content of poultry manure. Anim. Feed Sci. Technol. 142:339-347.

11. O’Dell, B. L., and J. E. Savage. 1960. Effect of phytic acid on zinc availability. Proc. Soc. Exp. Biol. Med. 103:304-306.

12. O’Dell, B. L., J. M. Yohe, and J. E. Savage. 1964. Zinc availability in the chick as affected by phytate, calcium, and ethylenediaminetetraacetate. Poult. Sci. 43:415-419.

13. Reece, F. N., B. D. Lott, and J. W. Deaton. 1985. The effects of feed form, grinding method, energy level, and gender on broiler performance in a moderate $\left(21^{\circ} \mathrm{C}\right)$ environment. Poult. Sci. 64:1834-1839.

14. Reece, F. N., B. D. Lott, and J. W. Deaton. 1986. Effects of environmental temperature and corn particle size on response of broilers to pelleted feed. Poult. Sci. 65:636-641.

15. Nir, I., G. Shefet, and Y. Aaroni. 1994. Effect of particle size on performance. 1. Corn. Poult. Sci. 73: 45-49

16. Nir, I., R. Hillel, G. Shefet, and Z. Nitsan. 1994. Effect of grain particle size on performance 2. Grain texture interactions. Poult. Sci. 73:781-791.

17. Lott, B. D., 1989. The Effect of Corn Particle Size on Water Consumption and Broiler Performance. Ph.D. dissertation. Mississippi State University, Mississippi State, MS.

18. Parsons, A. S., N. P. Buchanon, K. P. Blemings, M. E. Wilson, and J. S. Moritz. 2006. Effect of corn particle size and pellet texture on broiler performance in the growing phase. J. Appl. Poult. Res. 15:245-255.

19. Behnke, K. C. 2001. Factors influencing pellet quality. Feed Technol. 5:19-22.

20. Lilly, K.G.S., C. K. Gehring, K. R. Beaman, P. J. Turk, M. Sperow, and J. S. Moritz. 2011. Examining the relationship between pellet quality, broiler performance, and bird sex. J.Appl. Poult. Res. 20: 231-239.

21. Svihus, B. 2010. Diet composition and processing adjustments to cover the bird's need for structural components. Pages 99-107 in Proc. $8^{\text {th }}$ Mid-Atlantic Nutr. Conf., Timonium, MD. Univ. Maryland, College Park.

22. AgriStats Inc., Fort Wayne, IN; 2013. 
23. RO-TAP RX-29, W.S. Tyler, Mentor, OH.

24. Master Model Pellet Mill, California Pellet Mills Company, Crawfordsville, IN.

25. Pellet quality was assessed one day following production using the New Holmen Portable Pellet Durability Tester, Lignotech USA, INC., Rothschild, WI. $100 \mathrm{~g}$ of pellets were sifted through No. 5 American Society for Testing and Materials (ASTM) screen and placed in holding chamber, blown for 30 seconds by a jet of air, then weighed, giving a direct read of pellet durability. Fines are removed during the blowing process.

26. Pilgrim's Pride Hatchery, Moorefield, WV.

27. New Jersey Feed Lab, Inc., Trenton, NJ.

28. SAS Institute. 2013. The SAS System for Windows 2013. Release 9.3. SAS Inst. Inc., Cary, NC.

29. Amerah, A. M., V. Ravindran, R. G. Lentle, and D. G. Thomas. 2008. Influence of feed particle size on the performance, energy utilization, digestive tract development, and digesta parameters of broiler starters fed wheat- and corn-based diets. Poult. Sci. 87(11):2320-2328.

30. Chewning, C. G., C. R. Stark, and J. Brake. 2012. Effects of particle size and feed form on broiler performance. J. Appl. Poult. Res. 21:830-837.

31. Moritz, J. S., K. J. Wilson, K. R. Cramer, R. S. Beyer, L. J. McKinney, W. B. Cavalcanti, and X. Mo. 2002. Effect of formulation density, moisture, and surfactant on feed manufacturing, pellet quality, and broiler performance. J. Appl. Poult. Res. 11:155-163.

32. Liu, S. B., S. F. Li, L. Lu, J. Xie, L. Y. Zhang, R. L. Wang, and X. G. Luo. 2013. The effectiveness of zinc proteinate for chicks fed a conventional corn-soybean diet. J. Appl. Poult. Res. 22:396-403.

33. Huang, Y. L., L. Lu, X. G. Luo, and B. Liu. 2007. An optimal dietary zinc level of broiler chicks fed a corn-soybean meal diet. Poult. Sci. 86:2582-2589.

34. Lott, B. D., E. J. Day, J. W. Deaton, and J. D. May. 1992. The effect of temperature, dietary energy level, and corn particle size on broiler performance. Poult. Sci. 71:618624. 
Table 1. Diet composition of starter, grower, and finisher phases

\begin{tabular}{|c|c|c|c|}
\hline Ingredient & $\operatorname{Starter}^{1}(\mathrm{~d} 1-10)$ & Grower $^{1}($ d 11-21) & Finisher $^{1}(\mathrm{~d} 22-40)$ \\
\hline & $\%$ & $\%$ & $\%$ \\
\hline Corn & 58.98 & 62.06 & 68.14 \\
\hline Soybean meal (48 \%) & 33.57 & 30.29 & 24.81 \\
\hline Soybean oil & 2.68 & 3.17 & 3.13 \\
\hline Limestone & 1.36 & 1.19 & 1.10 \\
\hline Dicalcium phosphate & 1.75 & 1.61 & 1.54 \\
\hline DL-Methionine & 0.36 & 0.32 & 0.21 \\
\hline L-Lysine $\mathrm{HCl}$ & 0.22 & 0.15 & 0.11 \\
\hline Vitamin/mineral premix ${ }^{2}$ & 0.25 & 0.25 & 0.25 \\
\hline Salt $(\mathrm{NaCl})$ & 0.26 & 0.24 & 0.21 \\
\hline Sodium bicarbonate & 0.30 & 0.30 & 0.30 \\
\hline L-Threonine & 0.10 & 0.05 & 0.03 \\
\hline BMD $60^{3}$ & 0.08 & 0.08 & 0.08 \\
\hline Coban $90^{4}$ & 0.05 & 0.05 & 0.05 \\
\hline Sand & 0.04 & 0.04 & 0.04 \\
\hline \multicolumn{4}{|c|}{ Calculated nutrients } \\
\hline $\mathrm{ME}(\mathrm{kcal} / \mathrm{kg})$ & 3030.5 & 3096.6 & 3162.7 \\
\hline $\mathrm{CP}(\%)$ & 21.26 & 19.80 & 17.50 \\
\hline Dig Lysine (\%) & 1.18 & 1.05 & 0.89 \\
\hline Dig TSAA (\%) & 0.91 & 0.85 & 0.70 \\
\hline Calcium (\%) & 0.96 & 0.86 & 0.80 \\
\hline \multicolumn{4}{|c|}{ Analyzed nutrients } \\
\hline Crude Protein (\%) & 19.20 & 18.73 & 17.03 \\
\hline Crude Fat (\%) & 4.50 & 5.00 & 5.15 \\
\hline Crude Fiber (\%) & 2.40 & 2.30 & 2.10 \\
\hline \multicolumn{4}{|c|}{ Analyzed Zn Concentration ${ }^{5}$ (mg/kg) } \\
\hline No Suppl & $\mathrm{ZnSO}_{4}$ & Zn-gly & Zn-HMTBA \\
\hline Starter & 104 & 103 & 109 \\
\hline Grower & 104 & 100 & 102 \\
\hline Finisher & 101 & 93.7 & 96.3 \\
\hline \multicolumn{4}{|c|}{ 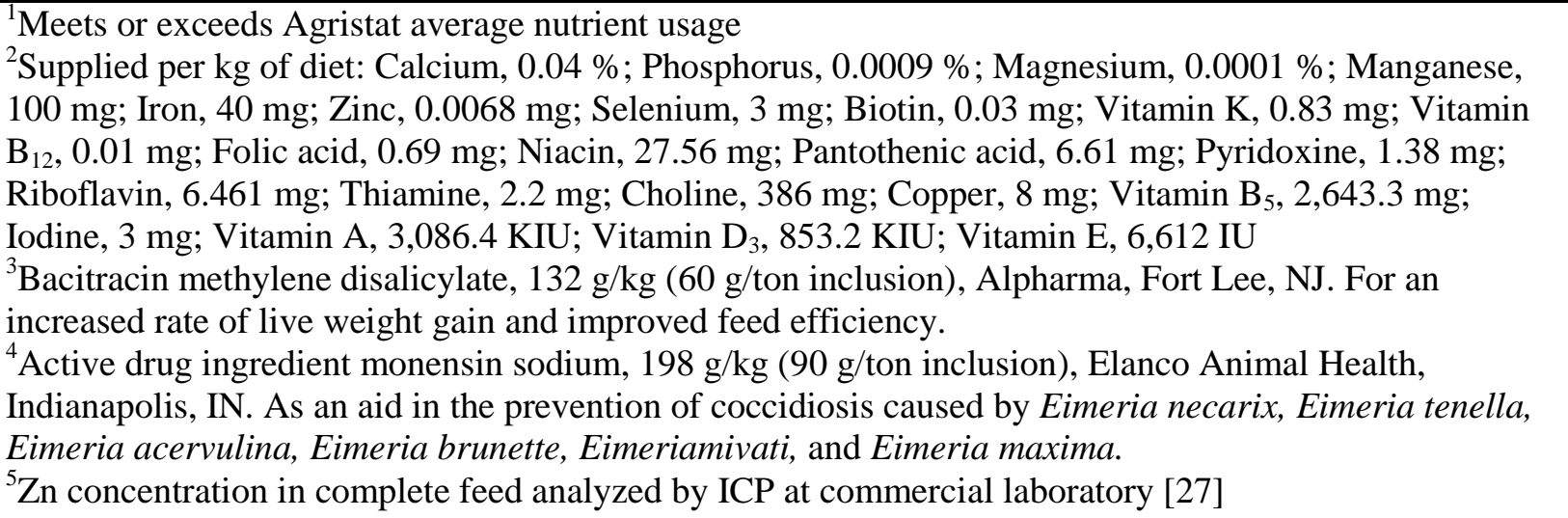 } \\
\hline
\end{tabular}


Table 2. Analyzed corn particle size and descriptive feed manufacture data

\begin{tabular}{|c|c|c|c|c|c|c|}
\hline & \multicolumn{2}{|c|}{ Starter } & \multicolumn{2}{|c|}{ Grower } & \multicolumn{2}{|c|}{ Finisher } \\
\hline & Small & Large & Small & Large & Small & Large \\
\hline 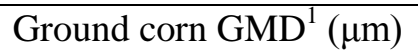 & 528.9 & 1053.9 & 547.3 & 970.7 & 538.6 & 1117.0 \\
\hline Ground corn GSD ${ }^{2}$ & 1.586 & 2.286 & 1.621 & 2.206 & 1.593 & 2.317 \\
\hline Conditioning temp $\left({ }^{\circ} \mathrm{C}\right)$ & 82.0 & 82.0 & 82.0 & 82.0 & 82.0 & 82.0 \\
\hline Production rate (tonne/hr) & 0.907 & 0.907 & 0.907 & 0.907 & 0.907 & 0.907 \\
\hline Ambient temp $\left({ }^{\circ} \mathrm{C}\right)$ & $9.4-14.4$ & $10.8-14.2$ & $9.5-13.9$ & $8.2-11.6$ & $14.3-19.7$ & $21.9-23.8$ \\
\hline $\mathrm{NHPT}^{3}(\%)$ & 86.2 & 82.3 & 87.0 & 87.3 & 83.6 & 80.7 \\
\hline
\end{tabular}

${ }^{1} \mathrm{GMD}=$ geometric mean diameter

${ }^{2} \mathrm{GSD}=$ geometric standard deviation

${ }^{3}$ NHPT $=$ New Holmen Pellet Tester [25] 
Table 3. Overall (d 1-40) Hubbard x Cobb straight-run broiler performance

\begin{tabular}{|c|c|c|c|c|c|c|}
\hline Corn Particle Size $^{1}$ & $\begin{array}{c}\text { Zinc } \\
\text { Supplement }^{2}\end{array}$ & $\begin{array}{c}\text { FI/bird }{ }^{3} \\
(\mathrm{~kg})\end{array}$ & $\begin{array}{c}\text { EBW/bird }^{4} \\
(\mathrm{~kg})\end{array}$ & $\begin{array}{c}\text { LWG/bird } \\
(\mathrm{kg})\end{array}$ & FCR $^{6}$ & $\begin{array}{c}\text { Mort }^{7} \\
\%\end{array}$ \\
\hline \multirow{5}{*}{$\begin{array}{c}\text { Small } \\
(550 \mu \mathrm{m})\end{array}$} & No Suppl & $4.171^{\mathrm{e}}$ & $2.480^{\mathrm{c}}$ & $2.410^{\mathrm{c}}$ & 1.673 & 2.17 \\
\hline & $\mathrm{ZnSO}_{4}$ & $4.359^{\mathrm{abc}}$ & $2.630^{\mathrm{a}}$ & $2.560^{\mathrm{a}}$ & 1.642 & 2.17 \\
\hline & Zn-gly & $4.464^{\mathrm{a}}$ & $2.654^{\mathrm{a}}$ & $2.582^{\mathrm{a}}$ & 1.663 & 3.80 \\
\hline & Zn-AA & $4.440^{\mathrm{a}}$ & $2.651^{\mathrm{a}}$ & $2.579^{\mathrm{a}}$ & 1.662 & 3.26 \\
\hline & Zn-HMTBA & $4.379^{\mathrm{ab}}$ & $2.642^{\mathrm{a}}$ & $2.572^{\mathrm{a}}$ & 1.649 & 2.72 \\
\hline \multirow{5}{*}{$\begin{array}{c}\text { Large } \\
(1,050 \mu \mathrm{m})\end{array}$} & No Suppl & $4.258^{\text {cde }}$ & $2.580^{\mathrm{ab}}$ & $2.508^{\mathrm{ab}}$ & 1.646 & 3.26 \\
\hline & $\mathrm{ZnSO}_{4}$ & $4.280^{\text {bcde }}$ & $2.587^{\mathrm{ab}}$ & $2.517^{\mathrm{ab}}$ & 1.648 & 2.17 \\
\hline & Zn-gly & $4.294^{\mathrm{bcd}}$ & $2.619^{a}$ & $2.548^{\mathrm{a}}$ & 1.622 & 2.72 \\
\hline & $\mathrm{Zn}-\mathrm{AA}$ & $4.216^{\mathrm{de}}$ & $2.530^{\mathrm{bc}}$ & $2.460^{b c}$ & 1.640 & 2.17 \\
\hline & Zn-HMTBA & $4.309^{\mathrm{bcd}}$ & $2.611^{\mathrm{a}}$ & $2.541^{\mathrm{a}}$ & 1.642 & 2.17 \\
\hline \multicolumn{7}{|c|}{ Corn Particle Size Means } \\
\hline $\begin{array}{c}\text { Small } \\
(550 \mu \mathrm{m})\end{array}$ & - & 4.363 & 2.611 & 2.540 & $1.658^{\mathrm{a}}$ & 2.83 \\
\hline $\begin{array}{c}\text { Large } \\
(1050 \mu \mathrm{m})\end{array}$ & - & 4.272 & 2.585 & 2.515 & $1.639^{\mathrm{b}}$ & 2.50 \\
\hline Corn Particle & ize $\mathrm{SEM}^{8}$ & 0.0184 & 0.0130 & 0.0130 & 0.0047 & 0.0052 \\
\hline \multicolumn{7}{|c|}{ Zinc Supplement Means } \\
\hline - & No Suppl & 4.215 & 2.530 & 2.459 & 1.660 & 2.72 \\
\hline - & $\mathrm{ZnSO}_{4}$ & 4.320 & 2.608 & 2.538 & 1.645 & 2.17 \\
\hline- & Zn-gly & 4.379 & 2.637 & 2.565 & 1.643 & 3.26 \\
\hline - & $\mathrm{Zn}-\mathrm{AA}$ & 4.328 & 2.591 & 2.520 & 1.651 & 2.72 \\
\hline- & Zn-HMTBA & 4.344 & 2.627 & 2.556 & 1.645 & 2.45 \\
\hline Zinc Suppleı & $n \mathrm{SEM}^{8}$ & 0.0291 & 0.0205 & 0.0205 & 0.0074 & 0.0082 \\
\hline \multicolumn{7}{|c|}{ Probability } \\
\hline \multicolumn{2}{|c|}{ Corn Particle Size } & 0.0008 & 0.1605 & 0.1661 & 0.0069 & 0.6571 \\
\hline \multicolumn{2}{|c|}{ Zinc Supplement } & 0.0028 & 0.0039 & 0.0039 & 0.4957 & 0.9130 \\
\hline \multicolumn{2}{|c|}{ Corn Particle Size x Zinc Supplement } & 0.0045 & 0.0081 & 0.0094 & 0.2121 & 0.8709 \\
\hline
\end{tabular}

${ }^{1}$ Actual corn particle size: Small $=528.9 \mu \mathrm{m}$ (starter), $547.3 \mu \mathrm{m}$ (grower), $538.6 \mu \mathrm{m}$ (finisher); Large $=$ $1,053.9 \mu \mathrm{m}$ (starter), $970.7 \mu \mathrm{m}$ (grower), $1,117.0 \mu \mathrm{m}$ (finisher)

${ }^{2} \mathrm{No}$ Suppl = no supplemental zinc; $\mathrm{ZnSO}_{4}=80 \mathrm{mg} / \mathrm{kg}$ zinc sulfate; $\mathrm{Zn}$-gly $=40 \mathrm{mg} / \mathrm{kg}$ zinc sulfate +40 $\mathrm{mg} / \mathrm{kg}$ zinc-glycine amino acid chelate; $\mathrm{Zn}-\mathrm{AA}=40 \mathrm{mg} / \mathrm{kg}$ zinc sulfate $+40 \mathrm{mg} / \mathrm{kg}$ zinc-amino acid complex; Zn-HMTBA $=40 \mathrm{mg} / \mathrm{kg}$ zinc sulfate $+40 \mathrm{mg} / \mathrm{kg}$ zinc bis(-2-hydroxy-4-methylthio)butanoic acid

${ }^{3} \mathrm{FI}=$ Feed Intake

${ }^{4} \mathrm{EBW}=$ Ending Body Weight

${ }^{5} \mathrm{LWG}=$ Live Weight Gain

${ }^{6} \mathrm{FCR}=$ mortality corrected Feed Conversion Ratio

${ }^{7}$ Mort $=$ Mortality

${ }^{8} \mathrm{SEM}=$ pooled Standard Error of the Mean 
Table 4. Hubbard x Cobb straight-run broiler performance within starter, grower, and finisher phases

\begin{tabular}{|c|c|c|c|c|c|c|c|c|c|c|c|c|c|}
\hline \multirow[b]{2}{*}{ Corn Particle Size ${ }^{1}$} & \multirow[b]{2}{*}{$\begin{array}{c}\text { Zinc } \\
\text { Supplement }^{2}\end{array}$} & \multicolumn{4}{|c|}{ Starter (d 1-10) } & \multicolumn{4}{|c|}{ Grower (d 11-22) } & \multicolumn{4}{|c|}{ Finisher (d 23-40) } \\
\hline & & $\begin{array}{c}\text { FI/bird }{ }^{3} \\
(\mathrm{~kg})\end{array}$ & $\begin{array}{c}\text { LWG/bird } \\
(\mathrm{kg})\end{array}$ & $\mathrm{FCR}^{5}$ & $\begin{array}{c}\text { Mort }^{6} \\
\%\end{array}$ & $\begin{array}{c}\text { FI/bird }{ }^{3} \\
\text { (kg) }\end{array}$ & $\begin{array}{c}\text { LWG/bird } \\
(\mathrm{kg})\end{array}$ & $\mathrm{FCR}^{5}$ & $\begin{array}{c}\text { Mort }^{6} \\
\%\end{array}$ & $\begin{array}{c}\text { FI/bird }{ }^{3} \\
(\mathbf{k g})\end{array}$ & $\begin{array}{c}\text { LWG/bird } \\
(\mathrm{kg})\end{array}$ & $\mathrm{FCR}^{5}$ & $\begin{array}{c}\text { Mort }^{6} \\
\%\end{array}$ \\
\hline \multirow{5}{*}{$\begin{array}{c}\text { Small } \\
(550 \mu \mathrm{m})\end{array}$} & No Suppl & 0.194 & 0.125 & 1.549 & 1.09 & 0.947 & 0.658 & 1.436 & 1.09 & $3.028^{\mathrm{e}}$ & 1.192 & 1.836 & - \\
\hline & $\mathrm{ZnSO}_{4}$ & 0.207 & 0.137 & 1.514 & 0.54 & 1.005 & 0.712 & 1.405 & 1.09 & $3.145^{\text {abcd }}$ & 1.231 & 1.811 & 0.54 \\
\hline & Zn-gly & 0.206 & 0.135 & 1.516 & 2.17 & 1.013 & 0.719 & 1.403 & 1.14 & $3.242^{\mathrm{a}}$ & 1.231 & 1.848 & 0.54 \\
\hline & $\mathrm{Zn}-\mathrm{AA}$ & 0.209 & 0.134 & 1.554 & 2.17 & 1.018 & 0.713 & 1.422 & 1.09 & $3.211^{\mathrm{ab}}$ & 1.253 & $\begin{array}{l}1.070 \\
1.829\end{array}$ & - \\
\hline & Zn-HMTBA & 0.206 & 0.139 & 1.478 & 1.63 & 1.011 & 0.711 & 1.419 & 0.54 & $3.161^{\mathrm{abc}}$ & 1.240 & 1.818 & 0.54 \\
\hline \multirow{5}{*}{$\begin{array}{c}\text { Large } \\
(1,050 \mu \mathrm{m})\end{array}$} & No Suppl & 0.188 & 0.124 & 1.513 & 1.09 & 0.948 & 0.661 & 1.424 & 1.66 & $3.119^{\text {bcde }}$ & 1.269 & 1.794 & 0.57 \\
\hline & $\mathrm{ZnSO}_{4}$ & 0.199 & 0.130 & 1.529 & 1.63 & 0.981 & 0.689 & 1.418 & 0.57 & $3.099^{\text {cde }}$ & 1.245 & 1.800 & - \\
\hline & Zn-gly & 0.195 & 0.132 & 1.473 & 0.54 & 0.982 & 0.697 & 1.407 & 0.57 & $3.116^{\text {bcde }}$ & 1.234 & 1.774 & 1.63 \\
\hline & $\mathrm{Zn}-\mathrm{AA}$ & 0.194 & 0.129 & 1.505 & 0.54 & 0.972 & 0.685 & 1.416 & 0.54 & $3.049^{\mathrm{de}}$ & 1.180 & 1.800 & 1.11 \\
\hline & Zn-HMTBA & 0.200 & 0.134 & 1.480 & 2.17 & 0.990 & 0.695 & 1.427 & - & $3.119^{\text {bcde }}$ & 1.254 & 1.795 & - \\
\hline \multicolumn{14}{|c|}{ Corn Particle Size Means } \\
\hline $\begin{array}{c}\text { Small } \\
(550 \mu \mathrm{m})\end{array}$ & - & $0.204^{\mathrm{a}}$ & $0.134^{\mathrm{a}}$ & 1.522 & 1.52 & $0.999^{\mathrm{a}}$ & $0.703^{\mathrm{a}}$ & 1.417 & 0.99 & 3.158 & 1.230 & $1.828^{\mathrm{a}}$ & 0.33 \\
\hline $\begin{array}{c}\text { Large } \\
(1050 \mu \mathrm{m})\end{array}$ & - & $0.195^{\mathrm{b}}$ & $0.130^{\mathrm{b}}$ & 1.500 & 1.20 & $0.975^{\mathrm{b}}$ & $0.685^{\mathrm{b}}$ & 1.418 & 0.67 & 3.100 & 1.236 & $1.793^{\mathrm{b}}$ & 0.66 \\
\hline Corn Particle S & ze $\mathrm{SEM}^{7}$ & 0.0017 & 0.0010 & 0.0171 & 0.0038 & 0.0039 & 0.0032 & 0.0045 & 0.0030 & 0.0163 & 0.0116 & 0.0067 & 0.0022 \\
\hline \multicolumn{14}{|c|}{ Zinc Supplement Means } \\
\hline - & No Suppl & $0.191^{\mathrm{b}}$ & $0.124^{\mathrm{c}}$ & 1.531 & 1.09 & $0.948^{\mathrm{b}}$ & $0.660^{\mathrm{b}}$ & 1.430 & 1.37 & 3.073 & 1.231 & 1.815 & 0.28 \\
\hline- & $\mathrm{ZnSO}_{4}$ & $0.203^{\mathrm{a}}$ & $0.133^{\mathrm{ab}}$ & 1.521 & 1.09 & $0.993^{\mathrm{a}}$ & $0.700^{\mathrm{a}}$ & 1.411 & 0.83 & 3.122 & 1.238 & 1.806 & 0.27 \\
\hline- & Zn-gly & $0.200^{\mathrm{a}}$ & $0.134^{\mathrm{ab}}$ & 1.494 & 1.36 & $0.998^{\mathrm{a}}$ & $0.708^{\mathrm{a}}$ & 1.405 & 0.85 & 3.179 & 1.232 & 1.811 & 1.09 \\
\hline - & $\mathrm{Zn}-\mathrm{AA}$ & $0.201^{\mathrm{a}}$ & $0.131^{\mathrm{b}}$ & 1.530 & 1.36 & $0.995^{\mathrm{a}}$ & $0.699^{\mathrm{a}}$ & 1.419 & 0.82 & 3.130 & 1.216 & 1.814 & 0.56 \\
\hline- & Zn-HMTBA & $0.203^{\mathrm{a}}$ & $0.136^{\mathrm{a}}$ & 1.479 & 1.90 & $1.000^{\mathrm{a}}$ & $0.703^{\mathrm{a}}$ & 1.423 & 0.27 & 3.140 & 1.247 & 1.807 & 0.27 \\
\hline Zinc Supplem & hEM SEM $^{7}$ & 0.0027 & 0.0015 & 0.0270 & 0.0060 & 0.0061 & 0.0050 & 0.0071 & 0.0048 & 0.0258 & 0.0184 & 0.0106 & 0.0034 \\
\hline & & & & & & obability & & & & & & & \\
\hline Corn Partic & Size & 0.0002 & 0.0019 & 0.3600 & 0.5458 & $<0.0001$ & 0.0003 & 0.8419 & 0.4579 & 0.0156 & 0.6812 & 0.0003 & 0.2791 \\
\hline Zinc Suppl & ment & 0.0125 & $<0.0001$ & 0.5647 & 0.8724 & $<0.0001$ & $<0.0001$ & 0.1088 & 0.6274 & 0.0808 & 0.8259 & 0.9562 & 0.3877 \\
\hline Corn Particle Size x 2 & inc Supplement & 0.7357 & 0.7246 & 0.8915 & 0.3708 & 0.1052 & 0.2122 & 0.7055 & 0.8983 & 0.0106 & 0.0865 & 0.2734 & 0.2243 \\
\hline
\end{tabular}

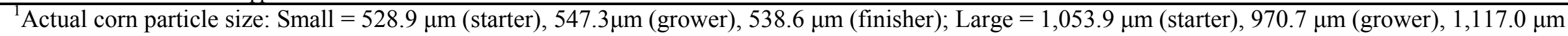
(finisher)

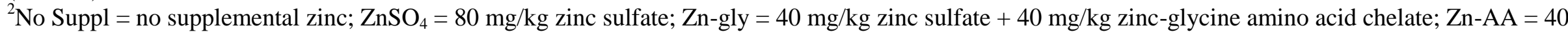

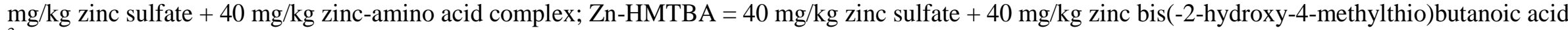
${ }^{3} \mathrm{FI}=$ Feed Intake

${ }^{4} \mathrm{LWG}=$ Live Weight Gain

${ }^{5} \mathrm{FCR}=$ mortality corrected Feed Conversion Ratio

${ }^{6}$ Mort $=$ Mortality

${ }^{7} \mathrm{SEM}=$ pooled Standard Error of the Mean 
Table 5. $\mathrm{d} 40$ hot breast yield and tibia ash analysis

\begin{tabular}{|c|c|c|c|c|c|}
\hline Corn Particle Size ${ }^{1}$ & $\begin{array}{c}\text { Zinc } \\
\text { Supplement }^{2} \\
\end{array}$ & $\begin{array}{c}\text { Breast Weight } \\
\text { (g) }\end{array}$ & $\begin{array}{c}\text { Breast Yield } \\
(\%)\end{array}$ & $\begin{array}{c}\text { Tibia Ash } \\
(\%)\end{array}$ & $\begin{array}{c}\text { Tibia [Zn] } \\
(\mathrm{mg} / \mathrm{kg})\end{array}$ \\
\hline \multirow{5}{*}{$\begin{array}{c}\text { Small } \\
(550 \mu \mathrm{m})\end{array}$} & No Suppl & 517.21 & 19.77 & 34.37 & $160.75^{b}$ \\
\hline & $\mathrm{ZnSO}_{4}$ & 516.13 & 19.51 & - & - \\
\hline & Zn-gly & 547.60 & 19.96 & - & - \\
\hline & Zn-AA & 546.21 & 19.83 & - & - \\
\hline & Zn-HMTBA & 544.06 & 19.89 & - & - \\
\hline \multirow{5}{*}{$\begin{array}{c}\text { Large } \\
(1,050 \mu \mathrm{m})\end{array}$} & No Suppl & 504.89 & 19.18 & 36.35 & $163.50^{\mathrm{b}}$ \\
\hline & $\mathrm{ZnSO}_{4}$ & 532.66 & 19.30 & 36.72 & $292.00^{\mathrm{a}}$ \\
\hline & $\mathrm{Zn}$-gly & 513.09 & 19.19 & 32.43 & $310.50^{\mathrm{a}}$ \\
\hline & Zn-AA & 491.11 & 19.09 & 34.56 & $293.50^{\mathrm{a}}$ \\
\hline & Zn-HMTBA & 514.83 & 19.63 & 34.34 & $314.75^{\mathrm{a}}$ \\
\hline \multicolumn{2}{|l|}{$\begin{array}{l}\text { Multiple Comparison } \\
P \text {-value }\end{array}$} & - & - & 0.0896 & $<0.0001$ \\
\hline \multicolumn{2}{|l|}{$\mathrm{SEM}^{4}$} & - & - & 1.0120 & 7.7483 \\
\hline \multicolumn{6}{|c|}{ Corn Particle Size Means } \\
\hline $\begin{array}{c}\text { Small } \\
(550 \mu \mathrm{m})\end{array}$ & - & $534.24^{\mathrm{a}}$ & $19.79^{\mathrm{a}}$ & - & - \\
\hline $\begin{array}{c}\text { Large } \\
(1050 \mu \mathrm{m})\end{array}$ & - & $511.32^{\mathrm{b}}$ & $19.28^{\mathrm{b}}$ & - & - \\
\hline \multirow{2}{*}{\multicolumn{2}{|c|}{ Corn Particle Size SEM ${ }^{4}$}} & 7.3491 & 1.7473 & - & - \\
\hline & & \multicolumn{2}{|c|}{ Zinc Supplement Means } & & \\
\hline- & No Suppl & 511.05 & 19.48 & - & - \\
\hline - & $\mathrm{ZnSO}_{4}$ & 524.39 & 19.40 & - & - \\
\hline - & Zn-gly & 530.34 & 19.57 & - & - \\
\hline - & $\mathrm{Zn}-\mathrm{AA}$ & 518.66 & 19.46 & - & - \\
\hline - & Zn-HMTBA & 529.45 & 19.76 & - & - \\
\hline \multirow{2}{*}{\multicolumn{2}{|c|}{ Zinc Supplement SEM ${ }^{4}$}} & 11.6200 & 2.7628 & - & - \\
\hline & & Probabi & & & \\
\hline \multicolumn{2}{|c|}{ Corn Particle Size } & 0.0307 & 0.0404 & - & - \\
\hline \multicolumn{2}{|c|}{ Zinc Supplement } & 0.7509 & 0.9029 & - & - \\
\hline \multicolumn{2}{|c|}{ Corn Particle Size X Zinc Supplement } & 0.2665 & 0.9209 & - & - \\
\hline
\end{tabular}

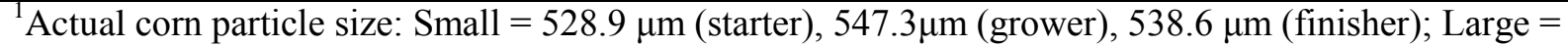
$1,053.9 \mu \mathrm{m}$ (starter), $970.7 \mu \mathrm{m}$ (grower), 1,117.0 $\mu \mathrm{m}$ (finisher)

${ }^{2} \mathrm{No}$ Suppl = no supplemental zinc; $\mathrm{ZnSO}_{4}=80 \mathrm{mg} / \mathrm{kg}$ zinc sulfate; $\mathrm{Zn}$-gly $=40 \mathrm{mg} / \mathrm{kg}$ zinc sulfate +40 $\mathrm{mg} / \mathrm{kg}$ zinc-glycine amino acid chelate; $\mathrm{Zn}-\mathrm{AA}=40 \mathrm{mg} / \mathrm{kg}$ zinc sulfate $+40 \mathrm{mg} / \mathrm{kg}$ zinc-amino acid complex; Zn-HMTBA $=40 \mathrm{mg} / \mathrm{kg}$ zinc sulfate $+40 \mathrm{mg} / \mathrm{kg}$ zinc bis(-2-hydroxy-4-methylthio)butanoic acid

${ }^{3} \mathrm{Zn}$ concentration in tibia ash analyzed by ICP at commercial laboratory [27]

${ }^{4} \mathrm{SEM}=$ pooled Standard Error of the Mean 


\title{
CHAPTER 3
}

Transgenic phytase corn and granulated phytase effects on mix uniformity, thermal stability, and pellet quality

\author{
K.L. Foltz, ${ }^{*}$ O. Gutierrez, ${ }^{\dagger}$ and J.S. Moritz ${ }^{*}, 1$ \\ *Division of Animal and Nutritional Sciences, West Virginia University, Morgantown, WV \\ 26506; and 'Huvepharma, Inc., Peachtree City, GA 30269
}

Primary audience: Nutritionists, Researchers, Technical Service Managers, Feed Mill Manager

${ }^{1}$ Corresponding author: jsmoritz@mail.wvu.edu 


\section{SUMMARY}

Transgenic phytase corn (TPC) represents an alternative to granulated phytase that may provide feed manufacture benefits especially when formulating for high phytase activity. Mixer added feed enzymes must disperse properly and maintain activity post pelleting. The objective of the study was to determine thermal stability, mixer coefficient of variation (CV), and pellet quality of TPC ground to two different particle sizes ( $2 \mathrm{~mm}$ and $3 \mathrm{~mm})$ and two concentrations of granulated Pichia pastoris phytase (5,100 and 15,300 FTU/g - AOAC 2000.12). The TPC products were analyzed to contain 3,400 FTU/g - AOAC 2000.12, and dyed green prior to feed manufacture. Four batches of feed were mixed containing each of four phytases. Each batch was split into three allotments that were steam conditioned and pelleted. Mash samples were collected from ten locations within the mixer to determine $\mathrm{CV}$ based on chloride ion concentration, TPC particle count per $100 \mathrm{~g}$, and TPC particle weight per $100 \mathrm{~g}$. Each allotment was conditioned at three temperatures $\left(80,85\right.$, and $\left.90{ }^{\circ} \mathrm{C}\right)$ and pelleted in a 4 (phytase) x 3 (conditioning temperature) factorial arranged in a randomized complete block design. Blocking criterion was time of day and treatments were replicated three times. Pellet durability, fines percentage, and phytase recovery post pelleting were determined. Coefficient of variation determined with chloride ion concentrations were lower than $\mathrm{CV}$ determined with dyed particle number or weight per $100 \mathrm{~g}$. The $2 \mathrm{~mm}$ TPC had a higher dyed particle number per $100 \mathrm{~g}$ than 3 mm TPC in both mash and pelleted samples $(P<0.05)$. Pellet durability increased and fines percentage decreased with increasing conditioning temperature $(P<0.05)$. Phytase and conditioning temperature interacted for recovery post-pelleting $(P<0.001)$. Phytase recovery generally declined with increased conditioning temperature. However, recovery among products was similar at 80 and $85{ }^{\circ} \mathrm{C}$ conditioning and higher for granulated compared to TPC at $90{ }^{\circ} \mathrm{C}$ conditioning. 
Key words: phytase, transgenic corn, pellet, retention, CV

\section{DESCRIPTION OF PROBLEM}

The main storage form of phosphorus $(\mathbf{P})$ in planta is phytate (myoinositolhexaphosphate; $\mathbf{I P}_{\mathbf{6}}$ ), which is largely unavailable to monogastric animals [1-4]. Phytate is a known anti-nutritional factor, affecting availability of minerals, dietary amino acids, and energy [4-7]. Addition of exogenous phytase to diets has been shown to increase phytate-P digestibility and alleviate anti-nutritive effects in swine and poultry $[3,5,8,9]$. Phytases are traditionally produced in microbial expression systems and commercialized as coated, granular, or liquid products. Transgenic grains expressing phytase have been explored as an alternative to microbial/granular phytase in poultry diets [10-15].

Pen et al. [10] reported that broilers yielded similar weight gain when fed diets with transgenic tobacco seeds expressing Aspergillus niger phytase compared to a microbial/granular A. niger phytase. Other authors have published similar results using transgenic soybeans and corn in broiler diets $[11,12]$. Plants constitute a larger land mass than microbial expression systems, and may be an economically feasible production system. Corn, unlike tobacco seeds, is a bulk ingredient in the majority of U.S. poultry diets and, unlike soybeans, is not subject to thermal processing prior to diet batching. The current study examined a transgenic phytase corn (TPC) product expressing an Escherichia coli phytase within the endosperm of the corn kernel.

Broilers are almost exclusively fed pelleted diets, due to associated benefits [16-21]. Mixer-added enzymes must disperse properly in mixing systems and maintain activity postpelleting. Literature assessing the thermal stability of transgenic seeds expressing phytase is limited, particularly throughout the pelleting process. Lucca et al. [22] found that an A. niger 
phytase expressed in rice only maintained $8 \%$ of its original activity after boiling in water for 20 min. Brinch-Pederson et al. [23] reported that an Aspergillis fumigatus phytase expressed in the endosperm of wheat maintained $8 \%$ of its initial activity compared to the purified A. fumigatus phytase that maintained $59 \%$ activity, under similar conditions. The objective of the current study was to determine mixer dispersion, thermal stability, and pellet quality of a Escherichia coli phytase expressed in TPC ground to two different sizes (2 and $3 \mathrm{~mm}$ ) compared to an E. coli phytase expressed in Pichia pastoris and granulated at two different concentrations.

\section{MATERIALS AND METHODS}

\section{Experimental Design}

Treatments were arranged in a 4 x 3 factorial randomized complete block design, with the main effects phytase product and conditioning temperature. Phytase products included two E. coli-derived phytases expressed in P. pastoris and granulated at two concentrations (GEP1 and GEP2; 5,100 and 15,300 FTU/g) and two E. coli-derived phytases expressed in TPC (2 and 3 $\mathrm{mm} ; 3,300$ and 3,400 FTU/g) (Table 1). Diets containing each product were subject to conditioning temperatures of 80,85 , and $90^{\circ} \mathrm{C}$ prior to pelleting. Each phytase product was included in a common broiler starter diet formulated based on U.S. average nutrient concentrations (Table 2) [24]. Actual particle size of TPC phytases was determined using a ROTAP sieve shaker [25]. Geometric mean diameter (GMD) of products was $1,965 \mu \mathrm{m}(2 \mathrm{~mm})$ and 2,836 $\mu \mathrm{m}(3 \mathrm{~mm})$, and geometric standard deviation (GSD) was 1.199 and 1.182, respectively (Table 3). 


\section{Feed Manufacture}

All feed manufacture was conducted at the West Virginia University pilot feed mill. Prior to feed manufacture, TPC phytases were coated with a sterile green dye for determining product dispersion upon mixing and pelleting. Inclusions of phytase products were as follows: $\operatorname{GEP} 1(5,100 \mathrm{FTU} / \mathrm{g})=0.075 \%, \operatorname{GEP} 2(15,300 \mathrm{FTU} / \mathrm{g})=0.025 \%, 2 \mathrm{~mm} \mathrm{TPC}=0.1 \%$, and 3 $\mathrm{mm}$ TPC $=0.1 \%$ (Table 2). Sand was used as filler for diets with GEP phytases to complete the $0.1 \%$ inclusion. Individual enzyme mixtures were prepared by mixing a phytase product, white salt, sand, and $2.27 \mathrm{~kg}$ of corn for 10 minutes in a 5-quart Hobart mixer, prior to batching of diets [26]. Four master batches (one per treatment) were processed in a 1-ton vertical screw Easy Automation Inc. mixer without previously listed ingredients for five minutes [27]. Enzyme mixtures were added to each master batch and mixed for an additional ten minutes. A $700 \mathrm{~g}$ sample was collected from the mixer without enzyme mixture to determine baseline phytase activity, and ten samples (700 g each) of the complete mash diet were collected from varying mixer locations for coefficient of variation $(\mathbf{C V})$ determination. Master batches were split equally into three allotments (136.1 kg each), corresponding to each replication. Each $136.1 \mathrm{~kg}$ allotment was steam conditioned in a $1.3 \times 0.31 \mathrm{~m}$ short-term conditioning barrel for approximately $10 \mathrm{~s}$ at 80,85 , and $90{ }^{\circ} \mathrm{C}$. Allotments were extruded through a 4 x $38 \mathrm{~mm}$ pellet die powered by a 40-horsepower California Pellet Mill [28]. Three samples (300 g each) per conditioning temperature were collected upon pellet die extrusion and cooled. An additional sample ( $4.5 \mathrm{~kg})$ was collected for each conditioning temperature as pellets exited the cooler deck discharge for pellet quality analyses. All feed manufacture occurred in one day and blocking criterion was time of day. Feed manufacture variables are depicted in Table 4. 


\section{Sample Analysis}

Complete mash diet samples $(\mathrm{n}=10)$ were analyzed for chloride ion concentration using QuanTab Test Strips [29] to determine mixer CV. Additionally, CV was calculated based on phytase activity. Complete diet mash $(\mathrm{n}=10)$ and pellet $(\mathrm{n}=9)$ samples from diets containing TPC phytase products were split using a Humboldt riffle-type sample splitter [30]. Dyed TPC particles within each representative sample were counted and weighed. Particle count and weight was standardized per $100 \mathrm{~g}$ of total sample. Mash samples (without enzyme mixture and complete diet) and cooled pellet samples were split into three separate samples [30]. Samples were analyzed at separate commercial laboratories for phytase activity (AOAC 2000.12 and Phytex) [31, 32]. Phytase activity of mash without enzyme was analyzed to obtain a baseline before enzyme addition. Relative recovery (\%) of phytase post-pelleting was reported based on activity in mash samples. Pellet durability index (PDI), modified PDI (MPDI), New Holmen pellet tester (NHPT), and fines percentage were determined for each conditioning temperature within each $136.1 \mathrm{~kg}$ allotment $[33,34]$.

\section{Statistical Analysis}

Analyses were conducted using the PROC GLM procedure of Statistical Analysis System (SAS) [35]. Dyed TPC particle count and weight were analyzed by one-way ANOVA. Other variables were analyzed in a 4 (Phytase) x 3 (Conditioning Temperature) factorial randomized complete block design with fixed effects. There were three replications per phytase and blocking criterion was time of day. The experimental unit was a $136.1 \mathrm{~kg}$ allotment of feed. Alpha level was set at 0.05 and post hoc comparisons were made using Fisher's LSD when F test was significant. 


\section{RESULTS AND DISCUSSION}

\section{Mix Uniformity}

In general, mixer $\mathrm{CV}$ determined by chloride ion concentration was lower than mixer $\mathrm{CV}$ determined by enzyme activity (Table 5). The TPC products tended to have higher CV based on enzyme activity, which could be expected due to larger particle size and low diet inclusion $(0.1$ \%). Pfost et al. [36] stated that a marker for testing mixer CV should have similar physical characteristics (i.e. particle size and density) with other ingredients, and analytical analysis variability must be less than mixer variation. Salt has a relatively small particle size and large density compared to 2 or $3 \mathrm{~mm}$ corn particles. Clark et al. [37] reported that salt (chloride ion) may not be the best marker for mixer $\mathrm{CV}$ due to its presence in $\mathrm{L}$-Lysine $\mathrm{HCl}$ and choline chloride, which were both included in the experimental diet. Therefore, enzyme activity could be a better indicator of mix $\mathrm{CV}$, especially when there is interest in the dispersion of products added in low inclusions or determining probability of enzyme intake for small chicks.

There were 14.5 more dyed TPC particles per $100 \mathrm{~g}(P<0.0001)$ in the $2 \mathrm{~mm}$ TPC treatment compared to $3 \mathrm{~mm}$ TPC, in the complete diet mash samples (Table 6). However, no differences were observed for particle weight per $100 \mathrm{~g}(P=0.56)$. In pellet samples, the $2 \mathrm{~mm}$ TPC had 8.56 more dyed particles per $100 \mathrm{~g}$ than $3 \mathrm{~mm}$ TPC $(P<0.05)$, but no difference in particle weight per $100 \mathrm{~g}$ (Table 7). The increase in number of dyed particles in pelleted versus mash samples can be attributed to particle size reduction at the die-roll interface of the pellet mill. These data suggest that $2 \mathrm{~mm}$ TPC may allow more opportunity for uptake by small chicks compared to $3 \mathrm{~mm}$ TPC. 


\section{Thermal Stability}

Phytase activity in experimental diets was calculated to be approximately $1,500 \mathrm{FTU} / \mathrm{kg}$ (Phytex). Phytase activity in mash samples without enzyme was determined to be between 1976 FTU/kg (Phytex), likely from wheat middlings in formulation. Due to differences in activity between treatments, thermal stability was recorded as percentage of recovery (relative recovery) based on complete diet mash activity of each dietary treatment (Table 8). There was a Phytase $\mathrm{x}$ Conditioning Temperature interaction for post-pelleting relative recovery of phytase $(P<0.001)$. At $80{ }^{\circ} \mathrm{C}, 2 \mathrm{~mm}$ TPC had the highest relative recovery (99.5\%) with other phytase treatments being similar. The $2 \mathrm{~mm}$ TPC had a higher relative recovery than $3 \mathrm{~mm}$ TPC with granulated phytases (GEP1 and GEP2) being intermediate at $85^{\circ} \mathrm{C}$, while granulated phytases had higher relative recovery at $90{ }^{\circ} \mathrm{C}$. Hence, granulated phytases were not affected as much by increasing conditioning temperature as TPC. Brinch-Pederson et al. [23] noted that the deposition of $A$. fumigatus phytase in the endosperm of transgenic wheat appeared to impede refolding of the enzyme at temperatures above the melting temperature $\left(\mathbf{T}_{m}\right)$. The process of granulating enzymes improves handling properties and additionally creates a water barrier for the enzyme itself. Therefore, it is logical that a granulated enzyme would be more thermally stable than a non-granulated enzyme.

\section{Pellet Quality}

All pellet quality metrics were affected by the main effects Phytase and Conditioning Temperature (Table 9). Fines percentage decreased at $90{ }^{\circ} \mathrm{C}$ compared to 80 and $85{ }^{\circ} \mathrm{C}$, while PDI, MPDI, and NHPT increased with increasing conditioning temperature $(P<0.0001)$. Fines percentage was lowest for $3 \mathrm{~mm}$ TPC and highest for granulated phytases (GEP1 and GEP2), 
while $2 \mathrm{~mm}$ TPC was intermediate $(P<0.0001)$. Pellet durability index, MPDI, and NHPT was reduced for GEP1 compared to other phytase products $(\mathrm{P}<0.0001)$, although differences were miniscule (i.e. 90.75 vs $91.93 \%$ for PDI). Therefore, pellet quality differences among the phytase products used in the current study would not be expected to affect performance in a live bird trial.

\section{CONCLUSIONS AND APPLICATIONS}

1) Two mm TPC demonstrated similar thermal stability to granulated phytase at $85^{\circ} \mathrm{C}$ steam conditioning and pelleting.

2) Within the current study, $2 \mathrm{~mm}$ TPC may be more similar to granulated phytases due to improved mix uniformity and post-pelleting activity, compared to $3 \mathrm{~mm}$ TPC.

3) Pellet quality should not be an area of concern when using these particular phytase products at low inclusion levels.

4) Chloride ion concentration may not be an appropriate measure of mix uniformity, particularly when dispersion of large particle ingredients is of interest. 


\section{REFERENCES AND NOTES}

1. Erdman, J. W. 1979. Oilseed phytates: Nutritional implications. J. Am. Oil Chem. Soc. 56(8):736-741.

2. Ravindran, V., G. Ravindran, and S. Sivalogan. 1994. Total and phytate phosphorus contents of various foods and feedstuffs of plant origin. Food Chem. 50:133-136.

3. Maenz, D. D. 2001. Enzymatic characteristics of phytases as they relate to their use in animal feeds. Pages 61-83 in Enzymes in Farm Animal Nutrition. M. R. Bedford and G. G. Partridge, ed. CAB International, Wallingford, UK.

4. Angel, R., N. M. Tamim, T. J. Applegate, A. S. Dhandu, and L. E. Ellestad. 2002. Phytic acid chemistry: Influence on phytin-phosphorus availability and phytase efficacy. J. Appl. Poult. Res. 11:471-480.

5. Cowieson, A. J., T. Acamovic, and M. R. Bedford. 2006. Phytic acid and phytase: Implications for protein utilization by poultry. Poult. Sci. 85:878-885.

6. Ravindran, V., S. Cabahug, G. Ravindran, P. H. Selle, and W. L. Bryden. 2000. Response of broiler chickens to microbial phytase supplementation as influenced by dietary phytic acid and non-phytate phosphorus levels. II. Effects on apparent metabolisable energy, nutrient digestibility and nutrient retention. Br. Poult. Sci. 41:2, 193-200.

7. Lonnerdal, B., L. Jayawickramaand, and E. L. Lien. 1999. Effect of reducing the phytate content and of partially hydrolyzing the protein in soy formula on zinc and copper absorption and status in infant rhesus monkeys and rat pups. Am. J. Clin. Nutr. 69:490496.

8. Ravindran, V., S. Cabahug, G. Ravindran, P. H. Selle, and W. L. Bryden. 2000. Response of broiler chickens to microbial phytase supplementation as influenced by dietary phytic acid and non-phytate phosphorus levels. II. Effects on apparent metabolisable energy, nutrient digestibility and nutrient retention. Br. Poult. Sci. 41:2, 193-200.

9. Simons, P. C. M., H. A. J. Versteegh, A. W. Jongbloed, P. A. Kemme, P. Slump, K. D. Bos, M. G. E. Wolters, R. F. Beudeker, and G. J. Verschoor. 1990. Improvement of phosphorus availability by microbial phytase in broilers and pigs. Br. J. Nutr. 64:525540 .

10. Pen, J., T. C. Verwoerd, P. A. van Paridon, R. F. Beudeker, P. J. M. van den Elzen, K. Geerse, J. D. van der Klis, H. A. J. Versteegh, A. J. J. van Ooyen, and A. Hoekema. 1993. Phytase-containing transgenic seeds as a novel feed additive for improved

phosphorus utilization. Nat. Biotechnol. 11:811-814. 
11. Denbow, D. M., E. A. Grabau, G. H. Lacy, E. T. Kornegay, D. R. Russell, and P. F. Umbeck. 1998. Soybeans transformed with a fungal phytase gene improve phosphorus availability for broilers. Poult. Sci. 77:878-881.

12. Nyannor, E. K. D. and O. Adeola. 2008. Corn expressing Escherichia Coli-derived phytase gene: Comparitive study in broiler chicks. Poult. Sci. 87:2015-2022.

13. Nyannor, E. K. D., M. R. Bedford, and O. Adeola. 2009. Corn expressing an Escherichia coli-derived phytase gene: Residual phytase activity and microstructure of digesta in broiler chicks. Poult. Sci. 88:1413-1420.

14. Gao, C. Q., C. Ji, L. H. Zhao, J. Y. Zhang, and Q. G. Ma. 2013. Phytase transgenic corn in nutrition of laying hens: Residual phytase activity and phytate phosphorus content in the gastrointestinal tract. Poult. Sci. 92:2923-2929.

15. Gao, C. Q., Q. G. Ma, C. Ji, X. G. Luo, H. F. Tang, and Y. M. Wei. 2012. Evaluation of the compositional and nutritional values of phytase transgenic corn to conventional corn in roosters. Poult. Sci. 91:1142-1148.

16. Behnke, K. C. 1996. Feed manufacturing technology: current issues and challenges. Anim. Feed Sci. Technol. 62:49-57.

17. Reece, F. N., B. D. Lott, and J. W. Deaton. 1985. The effects of feed form, grinding method, energy level, and gender on broiler performance in a moderate $(21 \mathrm{C})$ environment. Poult. Sci. 64:1834-1839.

18. Nir, I., R. Hillel, I. Ptichi, and G. Shefet. 1995. Effect of particle size on performance. 3. Grinding pelleting interactions. Poult. Sci. 74:771-783.

19. Buchanan, N. P. and J. S. Moritz. 2009. Main effects and interactions of varying formulation protein, fiber, and moisture on feed manufacture and pellet quality. J. Appl. Poult. Res. 18(2):274-283.

20. Lilly, K. G. S., C. K. Gehring, K. R. Beaman, P. J. Turk, M. Sperow, and J. S. Moritz. 2011. Examining the relationships between pellet quality, broiler performance, and bird sex. J. Appl. Poult. Res. 20(2):231-239.

21. Abdollahi, M. R., V. Ravindran, and B. Svihus. 2013. Pelleting of broiler diets: An overview with emphasis on pellet quality and nutritional value. Anim. Feed Sci. Technol. 179:1-23.

22. Lucca, P., R. Hurrell, and I. Potrykus. 2001. Genetic engineering approaches to improve the bioavailability and the level of iron in rice grains. Theor. Appl. Genet. 102:392-397. 
23. Brinch-Pederson, H., F. Hatzach, E. Stöger, E. Arcalis, K. Pontopidan, and P. B. Holm. 2006. Heat-stable phytases in transgenic wheat (Triticum aestivum L.): Deposition pattern, thermostability, and phytate hydrolysis. J. Agric. Food Chem. 54:4624-4632.

24. AgriStats Inc., Fort Wayne, IN; 2013.

25. RO-TAP RX-29, W.S. Tyler, Mentor, OH.

26. Hobart, Troy, OH.

27. MFP Vertical Mixer, Easy Automation Inc., Welcome, MN.

28. Master Model Pellet Mill, California Pellet Mills Company, Crawfordsville, IN.

29. Chloride QuanTab Test Strips, 30-600 mg/L, Hach, Loveland, CO.

30. Humboldt Mfg. Co., Elgin, IL.

31. Enzyvia, LLC., Sheridan, IN.

32. Eurofins Nutrition Analysis Center, Des Moines, IA.

33. Pellet durability index was determined by sifting $500 \mathrm{~g}$ of pellets from a treatment through a No. 5 American Society for Testing and Materials (ASTM) screen before being deposited into a Pfost tumbler. The sifted pellets were then tumbled in the container, dimensions $5 \times 12 \times 12$ in., with a $2 \times 9$ in. plate fixed diagonally along the $12 \times 12$ in. side, for approximately $10 \mathrm{~min}$ at $50 \mathrm{rpm}$. The sample was then sifted again through the No. 5 (ASTM) mm screen, weighed, and the percentage of pellets was calculated by dividing the weight of pellets after tumbling by the weight of pellets before tumbling and then multiplying that value by 100 . Modified pellet durability index was similarly measured, with the exception of the addition of five, $13-\mathrm{mm}$ hexagonal bolts to the $500 \mathrm{~g}$ of sample in the tumbler.

34. New Holmen Pellet Tester, Lignotech USA, Inc., Rothschild, WI. $100 \mathrm{~g}$ of pellets were sifted through No. 5 American Society for Testing and Materials (ASTM) screen and placed in holding chamber, blown for 30 seconds by a jet of air, then weighed, giving a direct read of pellet durability.

35. SAS Institute. 2013. The SAS System for Windows 2013. Release 9.3. SAS Inst. Inc., Cary, NC.

36. Pfost, H. B., C. Deyoe, C. Stevens, and E. Morgan. 1966. Testing feed mixtures, mixers, and related equipment. Feedstuffs. 38:32-46. 
37. Clark, P. M., K. C. Behnke, and D. R. Poole. 2007. Effects of marker selection and mix time on the coefficient of variation (mix uniformity) of broiler feed. J. Appl. Poult. Res. 16:464-470. 
Table 1. Initial test product activity benchmarking

\begin{tabular}{|c|c|c|}
\hline Phytase & $\begin{array}{c}\text { Phytex Activity } \\
\text { (FTU/g) }\end{array}$ & $\begin{array}{c}\text { AOAC }(2000.12) \\
\text { Activity }^{(}(\text {FTU/g) }\end{array}$ \\
\hline GEP1 & 2,483 & 5,085 \\
\hline GEP2 & 6,800 & 15,323 \\
\hline $2 \mathrm{~mm}$ TPC & 1,605 & 3,345 \\
\hline $3 \mathrm{~mm}$ TPC & 1,521 & 3,414 \\
\hline
\end{tabular}

${ }^{1}$ Enzyvia, LLC. Sheridan, IN 
Table 2. Composition of broiler starter experimental diet

\begin{tabular}{lc}
\hline \multicolumn{1}{c}{ Ingredient } & Inclusion (\%) $^{\mathbf{1}}$ \\
\hline Corn & 58.85 \\
Soybean Meal (48 \%) & 29.55 \\
Wheat Middlings & 5.00 \\
Soybean Oil & 2.78 \\
Dicalcium Phosphate & 1.32 \\
Limestone & 1.18 \\
DL-Methionine & 0.41 \\
Salt (NaCl) & 0.27 \\
Vitamin/mineral Premix ${ }^{2}$ & 0.25 \\
Sodium Bicarbonate & 0.15 \\
L-Lysine HCl & 0.09 \\
L-Threonine & 0.05 \\
Enzyme & $0.025-0.1$ \\
Sand & \\
& $0-0.075$ \\
$\quad$ Calculated Nutrients & \\
ME (kcal/kg) & 3031 \\
CP (\%) & 19.13 \\
Calcium (\%) & 0.80 \\
Available P (\%) & 0.38 \\
Dig Met (\%) & 0.47 \\
Dig Met + Cyst (\%) & 1.01 \\
Dig Lys (\%) & 1.00 \\
\hline
\end{tabular}

${ }^{1}$ Meets or exceeds U.S. average nutrient concentrations (AgriStats, Inc., Fort Wayne, IN $; 2013$ )

${ }^{2}$ Supplied per kg of diet: manganese, $0.02 \%$; zinc $0.02 \%$; iron, $0.01 \%$; copper, $0.0025 \%$; iodine, $0.0003 \%$; selenium, $0.00003 \%$; folic acid, $0.69 \mathrm{mg}$; choline, $386 \mathrm{mg}$; riboflavin, $6.61 \mathrm{mg}$; biotin, $0.03 \mathrm{mg}$; vitamin B6, $1.38 \mathrm{mg}$; niacin,

27.56mg; pantothenic acid, $6.61 \mathrm{mg}$; thiamine, $2.20 \mathrm{mg}$; manadione, $0.83 \mathrm{mg}$; vitamin B12, $0.01 \mathrm{mg}$; vitamin E, 16.53 IU; vitamin D3, 2133 ICU; vitamin A, 7716 IU

${ }^{3} \mathrm{GEP} 1=0.075 \% ; \mathrm{GEP} 2=0.025 \% ; 2 \mathrm{~mm}$ TPC $=0.1 \% ; 3 \mathrm{~mm}$ TPC $=0.1 \%$

${ }^{4}$ Sand used as a filler 
Table 3. Actual corn particle size of TPC Corn products

\begin{tabular}{|c|c|c|}
\hline Treatment & 2 mm TPC & 3 mm TPC \\
\hline Expected GMD $(\mu \mathrm{m})^{\text {Actual GMD }}(\mu \mathrm{m})$ & 2,000 & 3,000 \\
\hline Actual GSD $^{1}$ & 1,965 & 2,836 \\
\hline
\end{tabular}

${ }^{1} 100 \mathrm{~g}$ sample processed through RO-TAP RX-29 sieve shaker (W.S. Tyler, Mentor, OH) in duplicate 
Table 4. Feed manufacture descriptive data

\begin{tabular}{|c|c|c|c|c|c|c|c|c|c|c|c|}
\hline Treatment & $\begin{array}{c}\text { Outsid } \\
\text { e Temp } \\
\left({ }^{\circ} \mathbf{C}\right)\end{array}$ & $\begin{array}{l}\text { Ambien } \\
\text { t Temp } \\
\left({ }^{\circ} \mathbf{C}\right)\end{array}$ & & litioni & & $\begin{array}{c}\text { Mash } \\
\text { Temp } \\
\left({ }^{\circ} \mathbf{C}\right)\end{array}$ & \multicolumn{3}{|c|}{ Hot Pellet Temp ${ }^{1}\left({ }^{\circ} \mathbf{C}\right)$} & $\begin{array}{c}\text { Pellet } \\
\text { Mill } \\
\text { Amperag } \\
\text { e }\end{array}$ & $\begin{array}{c}\text { Productio } \\
\text { n Rate }^{2} \\
\text { (MT/hr) }\end{array}$ \\
\hline \multicolumn{12}{|c|}{ Replication 1} \\
\hline GEP1 & 9.4 & 27.8 & 80 & 85 & 90 & 18.7 & 81.1 & 85.1 & 88.6 & $18.3-19.9$ & 0.775 \\
\hline GEP2 & 8.9 & 26.1 & 80 & 85 & 90 & 19.8 & 80.8 & 85.1 & 89.9 & $18.4-19.9$ & 0.724 \\
\hline $\begin{array}{c}2 \mathrm{~mm} \\
\mathrm{TPC}\end{array}$ & 9.4 & 26.1 & 80 & 85 & 90 & 18.7 & 81.9 & 85.1 & 89.8 & $18.1-19.8$ & 0.748 \\
\hline $\begin{array}{c}3 \mathrm{~mm} \\
\mathrm{TPC}\end{array}$ & 10.0 & 26.1 & 80 & 85 & 90 & 18.3 & 80.1 & 85.2 & 89.4 & $18.2-21.1$ & 0.718 \\
\hline \multicolumn{12}{|c|}{ Replication 2} \\
\hline GEP1 & 11.7 & 29.4 & 80 & 85 & 90 & 15.0 & 82.0 & 85.1 & 89.4 & $18.1-20.4$ & 0.790 \\
\hline GEP2 & 10.6 & 28.9 & 80 & 85 & 90 & 18.9 & 82.4 & 85.6 & 89.5 & $17.9-19.9$ & 0.796 \\
\hline $\begin{array}{c}2 \mathrm{~mm} \\
\mathrm{TPC}\end{array}$ & 8.9 & 28.9 & 80 & 85 & 90 & 19.2 & 82.6 & 85.4 & 89.8 & $18.7-20.4$ & 0.777 \\
\hline $\begin{array}{c}3 \mathrm{~mm} \\
\text { TPC }\end{array}$ & 11.7 & 29.4 & 80 & 85 & 90 & 19.2 & 82.0 & 85.3 & 90.1 & $17.7-20.0$ & 0.791 \\
\hline \multicolumn{12}{|c|}{ Replication 3} \\
\hline GEP1 & 11.1 & 28.9 & 80 & 85 & 90 & 18.9 & 82.3 & 85.5 & 89.9 & $17.6-19.2$ & 0.808 \\
\hline GEP2 & 10.0 & 28.3 & 80 & 85 & 90 & 18.8 & 82.3 & 85.4 & 89.7 & $17.8-19.5$ & 0.806 \\
\hline $\begin{array}{c}2 \mathrm{~mm} \\
\mathrm{TPC}\end{array}$ & 9.4 & 27.2 & 80 & 85 & 90 & 19.2 & 82.7 & 85.2 & 90.3 & $17.2-19.1$ & 0.808 \\
\hline $\begin{array}{c}3 \mathrm{~mm} \\
\mathrm{TPC}\end{array}$ & 11.1 & 29.4 & 80 & 85 & 90 & 19.1 & 83.2 & 85.5 & 88.9 & $17.9-19.7$ & 0.803 \\
\hline
\end{tabular}

${ }^{\mathrm{I}}$ Sample taken post extrusion from pellet die

${ }^{2}$ Calculated based on treatment processing time 
Table 5. Coefficient of variation based on chloride ion concentration and phytase activity in complete diet mash samples

\begin{tabular}{|c|c|c|c|}
\hline Method & Phytase & Average & $\mathrm{CV}^{3}(\%)$ \\
\hline \multirow{4}{*}{ Chloride Ion Concentration ${ }^{1}$} & GEP1 & 221.75 ppm & 7.58 \\
\hline & GEP2 & $214.75 \mathrm{ppm}$ & 15.76 \\
\hline & $2 \mathrm{~mm}$ TPC & $199.70 \mathrm{ppm}$ & 7.49 \\
\hline & $3 \mathrm{~mm}$ TPC & $197.15 \mathrm{ppm}$ & 15.05 \\
\hline \multirow{4}{*}{ Enzyme Activity $^{2}$ (Phytex) } & GEP1 & 2,137 FTU/kg & 13.06 \\
\hline & GEP2 & 2,337 FTU/kg & 14.69 \\
\hline & $2 \mathrm{~mm}$ TPC & $1,168 \mathrm{FTU} / \mathrm{kg}$ & 27.29 \\
\hline & $3 \mathrm{~mm} \mathrm{TPC}$ & $1,627 \mathrm{FTU} / \mathrm{kg}$ & 48.06 \\
\hline
\end{tabular}

${ }^{1}$ Chloride QuanTab Test Strips, 30-600 mg/L, Hach, Loveland, CO

${ }^{2}$ Enzyvia, LLC. Sheridan, IN

${ }^{3}$ Based on complete diet mash samples $(\mathrm{n}=10)$ 
Table 6. Dyed phytase corn particle analysis in mash feed

\begin{tabular}{|c|c|c|c|c|}
\hline Treatment & $\begin{array}{c}\text { Particles / } 100 \mathrm{~g} \\
\text { feed }^{1,2}\end{array}$ & $\begin{array}{c}\text { CV for } \\
\text { Particles/100 g } \\
(\%)\end{array}$ & $\begin{array}{c}\text { Particle wt (mg) / } \\
\quad 100 \text { feed }^{3}\end{array}$ & $\begin{array}{c}\text { CV for Particle } \\
\text { wt/100 g }(\%)\end{array}$ \\
\hline $2 \mathrm{~mm}$ TPC & $19.392^{\mathrm{a}}$ & 19.62 & 95.304 & 28.04 \\
\hline $3 \mathrm{~mm}$ TPC & $4.884^{\mathrm{b}}$ & 22.27 & 88.628 & 26.82 \\
\hline$P$ - value & $<0.0001$ & - & 0.5623 & - \\
\hline $\mathrm{SEM}^{4}$ & 0.8848 & - & 7.9978 & - \\
\hline
\end{tabular}

${ }^{1}$ Mash samples $(\mathrm{n}=10)$ were split using Humboldt riffle-type sample splitter (Humboldt Mfg. Co., Elgin, IL) and dyed phytase corn particles were counted within split sample. Each sample was standardized per $100 \mathrm{~g}$ of total sample.

${ }^{2} 100 \mathrm{~g}$ is the cumulative feed consumption of a 5-day-old Cobb 500 broiler chick and daily feed consumption of a 19-day-old broiler chick (Cobb 500 Broiler Performance \& Nutrition Supplement, Cobb-Vantress, Inc., Siloam Springs, AR)

${ }^{3}$ Dyed phytase corn particles within each sample were weighed and standardized (mg per $100 \mathrm{~g}$ of total sample)

${ }^{\mathrm{a}-\mathrm{b}}$ Means within a column without a common superscript differ significantly $(\mathrm{P} \leq 0.05)$

${ }^{4}$ Pooled standard error of the mean 
Table 7. Dyed phytase corn particle analysis in pelleted feed

\begin{tabular}{|c|c|c|c|c|c|}
\hline Phytase & $\begin{array}{c}\text { Conditioning Temp } \\
\left({ }^{\circ} \mathbf{C}\right)\end{array}$ & $\begin{array}{c}\text { Particles / } \\
100 \text { g feed }^{1,2}\end{array}$ & $\begin{array}{c}\text { CV for } \\
\text { Particles/100 g } \\
(\%)\end{array}$ & $\begin{array}{c}\text { Particle wt } \\
\text { (mg) / 100 g } \\
\text { feed }^{3}\end{array}$ & $\begin{array}{c}\text { CV for } \\
\text { Particle } \\
\text { wt/100 g }(\%)\end{array}$ \\
\hline \multirow{3}{*}{$2 \mathrm{~mm}$ TPC } & 80 & 31.967 & 8.74 & 87.428 & 20.86 \\
\hline & 85 & 26.071 & 13.68 & 81.418 & 13.41 \\
\hline & 90 & 29.269 & 32.02 & 87.175 & 35.71 \\
\hline \multirow{3}{*}{$3 \mathrm{~mm}$ TPC } & 80 & 20.495 & 35.08 & 83.645 & 36.29 \\
\hline & 85 & 25.639 & 24.49 & 108.717 & 12.77 \\
\hline & 90 & 15.498 & 21.25 & 66.983 & 32.18 \\
\hline \multicolumn{6}{|c|}{ Phytase Means } \\
\hline $2 \mathrm{~mm}$ TPC & - & $29.102^{\mathrm{a}}$ & - & 85.340 & - \\
\hline $3 \mathrm{~mm}$ TPC & - & $20.544^{b}$ & - & 86.450 & - \\
\hline & $\mathrm{SEM}^{4}$ & 2.1333 & - & 7.2791 & - \\
\hline \multicolumn{6}{|c|}{ Conditioning Temperature Means } \\
\hline- & 80 & 26.231 & - & 85.540 & - \\
\hline- & 85 & 25.855 & - & 95.070 & - \\
\hline- & 90 & 22.384 & - & 77.080 & - \\
\hline & $\mathrm{SEM}^{4}$ & 2.6128 & - & 8.9151 & - \\
\hline \multicolumn{6}{|c|}{ Probability } \\
\hline & Phytase & 0.0176 & - & 0.9164 & - \\
\hline Condit & oning Temperature & 0.5385 & - & 0.3956 & - \\
\hline Phytase x C & nditioning Temperature & 0.2054 & - & 0.2103 & - \\
\hline
\end{tabular}

${ }^{1}$ Pellet samples ( $\mathrm{n}=9$ ) were split using Humboldt riffle-type sample splitter (Humboldt Mfg. Co., Elgin, IL) and dyed phytase corn particles were counted within split sample. Each sample was standardized per $100 \mathrm{~g}$ of total sample.

${ }^{2} 100 \mathrm{~g}$ is the cumulative feed consumption of a 5-day-old Cobb 500 broiler chick and daily feed consumption of a 19-day-old broiler chick (Cobb 500 Broiler Performance \& Nutrition Supplement, Cobb-Vantress, Inc., Siloam Springs, AR)

${ }^{3}$ Dyed phytase corn particles within each sample were weighed and standardized (mg per $100 \mathrm{~g}$ of total sample).

${ }^{\mathrm{a}-\mathrm{b}}$ Means within a column without a common superscript differ significantly $(\mathrm{P} \leq 0.05)$

${ }^{4}$ Pooled standard error of the mean 
Table 8. Post-pelleting enzyme activity relative recovery ${ }^{1}$

\begin{tabular}{|c|c|c|c|c|}
\hline Phytase & $\begin{array}{l}\text { Conditioning } \\
\text { Temp }\left({ }^{\circ} \mathrm{C}\right)\end{array}$ & $\begin{array}{c}\text { Mash } \\
\text { Activity } \\
\text { (Phytex) } \\
\text { (FTU/kg) }\end{array}$ & $\begin{array}{c}\text { Relative } \\
\text { Recovery }^{2} \\
(\%)\end{array}$ & $\begin{array}{l}\text { Hot Pellet } \\
\text { Temp }\left({ }^{\circ} \mathrm{C}\right)\end{array}$ \\
\hline \multirow{3}{*}{ GEP1 } & 80 & \multirow{3}{*}{2,137} & $59.913^{\text {bc }}$ & 81.800 \\
\hline & 85 & & $47.372^{\mathrm{cd}}$ & 85.233 \\
\hline & 90 & & $45.204^{\mathrm{cd}}$ & 89.300 \\
\hline \multirow{3}{*}{ GEP2 } & 80 & \multirow{3}{*}{2,337} & $63.714^{b c}$ & 81.833 \\
\hline & 85 & & $47.540^{\mathrm{cd}}$ & 85.367 \\
\hline & 90 & & $45.514^{\text {cd }}$ & 89.700 \\
\hline \multirow{3}{*}{$2 \mathrm{~mm}$ TPC } & 80 & \multirow{3}{*}{1,168} & $99.543^{\mathrm{a}}$ & 82.400 \\
\hline & 85 & & $59.589^{\text {bc }}$ & 85.233 \\
\hline & 90 & & $23.459^{\mathrm{e}}$ & 89.967 \\
\hline \multirow{3}{*}{$3 \mathrm{~mm}$ TPC } & 80 & \multirow{3}{*}{1,627} & $78.345^{\mathrm{b}}$ & 81.767 \\
\hline & 85 & & $33.313^{\mathrm{de}}$ & 85.333 \\
\hline & 90 & & $15.591^{\mathrm{e}}$ & 89.467 \\
\hline \multicolumn{5}{|c|}{ Phytase Means } \\
\hline GEP1 & - & - & 50.829 & 85.444 \\
\hline GEP2 & - & - & 52.256 & 85.633 \\
\hline $2 \mathrm{~mm}$ TPC & - & - & 60.864 & 85.867 \\
\hline $3 \mathrm{~mm}$ TPC & - & - & 42.416 & 85.522 \\
\hline \multicolumn{2}{|c|}{ SEM $^{3}$} & - & 3.7502 & 0.1767 \\
\hline \multicolumn{5}{|c|}{ Conditioning Temperature Means } \\
\hline- & 80 & - & 75.379 & $81.950^{c}$ \\
\hline- & 85 & - & 46.953 & $85.292^{b}$ \\
\hline- & 90 & - & 32.442 & $89.608^{\mathrm{a}}$ \\
\hline \multicolumn{2}{|c|}{$\mathrm{SEM}^{3}$} & - & 3.2477 & 0.1530 \\
\hline \multicolumn{5}{|c|}{ Probability } \\
\hline \multicolumn{2}{|c|}{ Phytase } & - & 0.0195 & 0.3772 \\
\hline \multirow{2}{*}{\multicolumn{2}{|c|}{$\begin{array}{c}\text { Conditioning Temperature } \\
\text { Phytase } \mathrm{x} \text { Conditioning Temperature }\end{array}$}} & - & $<0.0001$ & $<0.0001$ \\
\hline & & - & 0.0008 & 0.8598 \\
\hline
\end{tabular}

${ }^{a-e}$ Means within a column without a common superscript differ significantly $(\mathrm{P} \leq 0.05)$

${ }^{1}$ Enzyvia, LLC., Sheridan, IN

${ }^{2}$ Calculated based on phytase activity in mash

${ }^{3}$ Pooled standard error of the mean 
Table 9. Fines and pellet durability data

\begin{tabular}{|c|c|c|c|c|c|}
\hline Phytase & $\begin{array}{c}\text { Conditioning } \\
\text { Temp }\left({ }^{\circ} \mathbf{C}\right)\end{array}$ & $\operatorname{Fines}^{1}(\%)$ & $\operatorname{PDI}^{2}(\%)$ & $\operatorname{MPDI}^{2}(\%)$ & $\operatorname{NHPT}^{3}(\%)$ \\
\hline \multirow{3}{*}{ GEP1 } & 80 & 2.818 & 88.737 & 85.493 & 82.367 \\
\hline & 85 & 2.607 & 90.380 & 87.620 & 86.510 \\
\hline & 90 & 2.253 & 93.143 & 91.563 & 89.797 \\
\hline \multirow{3}{*}{ GEP2 } & 80 & 2.866 & 89.603 & 86.513 & 85.320 \\
\hline & 85 & 2.587 & 91.143 & 88.860 & 87.897 \\
\hline & 90 & 2.071 & 93.637 & 91.990 & 92.457 \\
\hline \multirow{3}{*}{$2 \mathrm{~mm}$ TPC } & 80 & 2.515 & 89.983 & 86.883 & 85.270 \\
\hline & 85 & 2.348 & 91.633 & 89.303 & 88.780 \\
\hline & 90 & 1.783 & 93.737 & 92.230 & 92.728 \\
\hline \multirow{3}{*}{$3 \mathrm{~mm}$ TPC } & 80 & 2.202 & 90.437 & 87.693 & 86.043 \\
\hline & 85 & 2.117 & 91.383 & 89.280 & 88.593 \\
\hline & 90 & 1.631 & 93.967 & 92.587 & 92.607 \\
\hline \multicolumn{6}{|c|}{ Phytase Means } \\
\hline GEP1 & - & $2.559^{\mathrm{a}}$ & $90.753^{\mathrm{c}}$ & $88.226^{\mathrm{c}}$ & $86.224^{b}$ \\
\hline GEP2 & - & $2.508^{\mathrm{a}}$ & $91.461^{b}$ & $89.121^{\mathrm{b}}$ & $88.558^{\mathrm{a}}$ \\
\hline $2 \mathrm{~mm}$ TPC & - & $2.216^{\mathrm{b}}$ & $91.784^{\mathrm{ab}}$ & $89.472^{\mathrm{ab}}$ & $88.926^{\mathrm{a}}$ \\
\hline $3 \mathrm{~mm}$ TPC & - & $1.983^{\mathrm{c}}$ & $91.929^{\mathrm{a}}$ & $89.853^{\mathrm{a}}$ & $89.081^{\mathrm{a}}$ \\
\hline \multicolumn{2}{|c|}{$\mathrm{SEM}^{4}$} & 0.0754 & 0.1523 & 0.1934 & 0.3602 \\
\hline \multicolumn{6}{|c|}{ Conditioning Temperature Means } \\
\hline- & 80 & $2.600^{\mathrm{a}}$ & $89.690^{\mathrm{c}}$ & $86.646^{\mathrm{c}}$ & $84.750^{\mathrm{c}}$ \\
\hline- & 85 & $2.415^{\mathrm{a}}$ & $91.135^{b}$ & $88.766^{b}$ & $87.945^{b}$ \\
\hline- & 90 & $1.935^{\mathrm{b}}$ & $93.621^{\mathrm{a}}$ & $92.093^{\mathrm{a}}$ & $91.897^{\mathrm{a}}$ \\
\hline \multicolumn{2}{|c|}{ SEM $^{4}$} & 0.0653 & 0.1319 & 0.1674 & 0.3119 \\
\hline \multicolumn{6}{|c|}{ Probability } \\
\hline \multicolumn{2}{|c|}{ Phytase } & $<0.0001$ & $<0.0001$ & $<0.0001$ & $<0.0001$ \\
\hline \multicolumn{2}{|c|}{ Conditioning Temperature } & $<0.0001$ & $<0.0001$ & $<0.0001$ & $<0.0001$ \\
\hline \multicolumn{2}{|c|}{ Phytase x Conditioning Temperature } & 0.9428 & 0.5809 & 0.5475 & 0.8393 \\
\hline \multicolumn{6}{|c|}{$\begin{array}{l}\text { Society for Testing and Materials (ASTM) screen before being deposited into a Pfost tumbler. The sifted pellets } \\
\text { were then tumbled in the container, dimensions } 5 \times 12 \times 12 \text { in., with a } 2 \times 9 \text { in. plate fixed diagonally along the } 12 \times \\
12 \text { in. side, for approximately } 10 \text { min at } 50 \mathrm{rpm} \text {. The sample was then sifted again through the No. } 5 \text { (ASTM) } \mathrm{mm} \\
\text { screen, weighed, and the percentage of pellets was calculated by dividing the weight of pellets after tumbling by the } \\
\text { weight of pellets before tumbling and then multiplying that value by } 100 \text {. Modified pellet durability index was } \\
\text { similarly measured, with the exception of the addition of five, } 13 \text {-mm hexagonal bolts to the } 500 \mathrm{~g} \text { of sample in the } \\
\text { tumbler. } \\
{ }^{3} \mathrm{New} \text { Holmen Pellet Tester, Lignotech USA, Inc., Rothschild, WI. } 100 \mathrm{~g} \text { of pellets were sifted through No. } 5 \\
\text { American Society for Testing and Materials (ASTM) screen and placed in holding chamber, blown for } 30 \text { seconds } \\
\text { by a jet of air, then weighed, giving a direct read of pellet durability. }\end{array}$} \\
\hline
\end{tabular}




\title{
CHAPTER 4
}

\section{Porcine feed intake of corn-soybean based diets supplemented with oil-extracted microalgae and subsequent performance}

\author{
K.L. Foltz, ${ }^{*}$ D. L. Smith, ${ }^{\dagger}$ and J.S. Moritz* \\ *Division of Animal and Nutritional Sciences, West Virginia University, Morgantown, WV \\ 26506; and Division of Animal Sciences, Eastern New Mexico University, Portales, NM 88130
}

Corresponding author: Joseph Moritz, P.O. Box 6108, Morgantown, WV 26506, Joe.Moritz@mail.wvu.edu 


\begin{abstract}
Oil-extracted microalgae are a co-product of biofuel production and have potential to be used as an animal feed ingredient. Three studies were conducted to determine the performance of grower-finisher pigs fed corn-soybean meal based diets supplemented with microalgae. In Study 1, twenty-six (8-week-old) Duroc x Yorkshire-Landrace pigs were fed diets containing 0, 1,2 , or $4 \%$ microalgae for a $14 \mathrm{~d}$ grow-out period. Average daily gain, ADFI, and G:F were similar among all treatments $(P>0.05)$. Additionally, pellet durability indices were numerically improved for diets containing $4 \%$ microalgae compared to the control diet. Based on Study 1 results, diets containing either 0 or $4 \%$ microalgae were selected to be replicated in Study 2 and 3. In both studies, pigs fed diets with $4 \%$ microalgae had similar ADG, ADFI, and G:F compared to pigs fed the control $(0 \%$ microalgae $)$ diet $(P>0.10)$. Feeding diets containing the oil-extracted microalgae used in the current study had no detriment to palatability or performance of growing pigs up to $4 \%$.
\end{abstract}

Keywords: microalgae, biofuel, oil-extracted, pigs 


\section{INTRODUCTION}

Increased crude oil prices and depleting supplies of non-renewable fuel sources have led to the exploration of alternative fuel sources. Microalgae is a promising candidate due to its rapid growing cycle, rich oil content, and ability to grow in non-arable regions without potable water (Chisti, 2007). Unlike oil crops (e.g., corn and soybeans), microalgae is not a major constituent in animal or human diets. Chisti (2007) estimated that $50 \%$ of the US transport fuel needs could be met if 1-3\% of US crop land produced algal biomass. As a co-product of algal biofuel production, a nutrient-rich dried biomass remains that has potential to be used in animal rations. Microalgae has an amino acid profile comparable to soybean meal (Becker, 2007), and contains significant amounts of carbohydrates, polyunsaturated lipids, and minerals.

The use of full-fat algae from various sources has been explored as an ingredient for animal feed for several decades (Grau and Klein, 1957; Hintz and Heitman, 1967; Ross and Dominy, 1990; Evans et al., 2015). However, its use in commercial diets is limited due to economic constraints. Authors have reported no detriment to growth rate or feed efficiency when supplementing protein sources with Cholorella and Scenedesmus spp. up to $10 \%$ in growing-finishing pigs (Hintz and Heitman, 1967), and up to $12 \%$ replacement of skim milk and soybean meal with Spirulina maxima in weanling pigs (Février and Sève, 1975). The use of algae for biofuel is relatively new, and little research has assessed the use of oil-extracted algae biomass in animal diets.

The objective of the current study was to assess feed intake and performance of growerfinisher pigs fed corn-soybean meal based diets containing oil-extracted microalgae. The microalga was obtained from a commercial biofuel company (Sapphire energy, San Diego, CA). 
Briefly, algae was grown in raceway ponds prior to oil extraction and refining, and received in a dried solid form.

\section{MATERIALS AND METHODS}

All animal protocols were in accordance with the West Virginia University Institutional Animal Care and Usage Committee.

\section{Study 1}

A total of 26 Duroc x Yorkshire-Landrace post-weaned pigs (8-week-old) were obtained from the Ohio State University Swine Center with an initial weight of $22.07 \pm 1.76 \mathrm{~kg}$. Pigs were housed at the West Virginia University swine facility with 13 (2.4 x $1.8 \mathrm{~m})$ pens. Pens were equipped with $1.2 \times 1.8$ m rubber stall mats and $15.2 \mathrm{~cm}$ enrichment balls. Each pen contained two nipple waterers and a galvanized $30.5 \mathrm{~W}$ x $50.8 \mathrm{~L}$ x $74.9 \mathrm{H} \mathrm{cm}$ one-hole feeder to provide ad libitum access to feed and water. Nutrient composition of oil-extracted microalgae biomass was determined for diet formulation (Table 1). Two diets were formulated based on NRC (2012) recommendations for growing pigs to be isocaloric and isonitrogenous and contain either 0 or $4 \%$ oil-extracted microalgae (Table 2 ).

All feed was manufactured at the West Virginia University pilot feed mill. Diets containing either 0 or $4 \%$ algae were batched according to calculated nutrient formulations (Table 2). Two intermediate diets ( 1 and $2 \%$ Algae) were created by blending the 0 and $4 \%$ diets. Each diet was steam conditioned at $82{ }^{\circ} \mathrm{C}$ for approximately $10 \mathrm{sec}$ and pelleted utilizing a 40-HP California Pellet Mill that extruded conditioned mash through a 4.8 x $44.5 \mathrm{~mm}$ die. Pellet durability index (PDI), modified PDI (MPDI), and pellet survivability using a New Holmen Pellet tester (NHPT) were used to determine the effect of oil-extracted microalgae on pellet quality one day post manufacture (Table 3). Pellet durability index was determined by sifting 
$500 \mathrm{~g}$ of pellets from a treatment through a No. 5 American Society for Testing and Materials (ASTM) screen before being placed into a Pfost tumbler. The sifted pellets were then tumbled in the container, dimensions $5 \times 12 \times 12$ in., with a $2 \times 9$ in. plate fixed diagonally along the $12 \times$ $12 \mathrm{in}$. side, for approximately $10 \mathrm{~min}$ at $50 \mathrm{rpm}$. The sample was then sifted again through the No. 5 (ASTM) mm screen, weighed, and the percentage of pellets was calculated by dividing the weight of pellets after tumbling by the weight of pellets before tumbling and then multiplying that value by 100 . Modified pellet durability index was similarly measured, with the exception of the addition of five, 13-mm hexagonal bolts to the $500 \mathrm{~g}$ of sample in the tumbler. New Holmen Pellet Tester (Lignotech USA, Inc., Rothschild, WI) pellet survivability was determined by sifting $100 \mathrm{~g}$ of pellets through a No. 5 American Society for Testing and Materials (ASTM) screen and placed in holding chamber, agitated for 30 seconds by a jet of air, then weighed, providing a measure of pellet survivability.

Twenty-four pigs were randomly assigned to 12 pens, with two pigs per pen. A randomized complete block design was used with location within the barn as the blocking factor. The number of barrows and gilts were equivalent for each treatment and there were a total of three replications per treatment. A control diet (0\% Algae) was fed d 1-7 and experimental diets were implemented on d 8-21. Pigs and feeders were weighed on d 1, 7, 14, and 21 to determine average daily gain (ADG), average daily feed intake (ADFI), and gain:feed ratio (G:F).

\section{Study 2 \& 3}

Based on data from study 1 , diets containing either 0 or $4 \%$ defatted algae were selected for the subsequent two studies. Twenty-one Duroc x Yorkshire-Landrace, crossbred, postweaned pigs (8-week-old) were obtained from the Ohio State University Swine Center for each 
study. Initial pig weights were $19.83 \pm 0.73$ and $19.14 \pm 1.20 \mathrm{~kg}$ for study 2 and 3 , respectively. Pigs were randomly assigned to one of ten pens in a randomized complete block design. There were five replications per treatment, for each study, and blocking criterion was location within the facility. Feed was manufactured in a similar manner to Study 1. A control diet was fed to all pigs from d 1-7. Experimental diets, containing 0 or $4 \%$ oil-extracted microalgae, were added on $\mathrm{d} 8$ and fed the remainder of the $14 \mathrm{~d}$ study period (e.g. $\mathrm{d} \mathrm{8-21).} \mathrm{Pigs} \mathrm{were} \mathrm{weighed} \mathrm{at} \mathrm{the}$ beginning of the acclimation period and every seven days thereafter. Performance data (ADG, ADFI, and G:F) were determined during the $14 \mathrm{~d}$ experimental period for each study.

\section{Statistical Analysis}

Data were analyzed in a randomized complete block design with pen location within the barn as blocking criterion. The experimental unit was a pen of two Duroc x Yorkshire-Landrace pigs. The PROC GLM procedure of SAS (SAS Institute Inc., Cary, NC) was used to analyze data by one-way ANOVA. Means were separated using Fisher's least significant difference (LSD) post hoc comparison when the ANOVA was significant $(P \leq 0.05)$. 


\section{RESULTS AND DISCUSSION}

\section{Study 1}

Pellet durability index, MPDI, and NHPT pellet survivability were numerically improved for diets containing $4 \%$ oil-extracted microalgae compared to the control diet (Table 3). Evans et al. (2015) reported that including full-fat Spirulina algae at $21 \%$ increased NHPT pellet survivability by $51.9 \%$ compared to a basal corn-soybean meal diet and proposed its use as a nutritive pellet binder. In the current study, a high inclusion of mixer-added fat (5.37-5.97\%) was used that explains the overall low pellet durability in comparison to the data presented by Evans et al. using 1.5-4.2\% mixer-added fat. Nonetheless, the $4 \%$ microalgae diet improved PDI, MPDI, and NHPT by 14.3, 39.3, and 46.2 \%, respectively, over the control diet (descriptive data). The full-fat microalgae used by Evans et al. had small particle size and high crude protein content $(76 \%)$. The authors suggested that the fine consistency of the algae may have filled interstitial space with the pellet or that the high protein content could have increased protein gelation and thus increased pellet survivability. The oil-extracted microalgae used in the current study had a larger particle size $(1,080 \mu \mathrm{m}$; data not included) and a crude protein of $35 \%$ (Table 1).

During the $14 \mathrm{~d}$ growth period ADG, ADFI, and G:F were similar among all treatments $(P>0.05)$ (Table 4). Numerically, pigs fed the $4 \%$ microalgae diet had the highest ADG at $1.036 \mathrm{~kg}$ and ADFI at $1.999 \mathrm{~kg}(P=0.21$ and $P=0.06$, respectively $)$. Microalgae inclusion had a visual impact on stool color as expected, but pigs had no apparent difficulty eating or digesting these diets as ADFI would suggest. From these data, it was determined that a microalgae inclusion level of $4 \%$ was not detrimental and could be used in the following two studies. 


\section{Study 2 \& 3}

Performance data for study $2 \& 3$ are presented in Table 5. There were no differences in performance metrics for either study $(P>0.10)$. These findings are similar to results observed by Isaacs et al. (2011) who found no detrimental effects to BW gain when weanling pigs were fed a diet in which soybean meal was directly replaced with $7 \%$ lipid-extracted Staurosira spp. microalgae. These authors additionally found that plasma urea nitrogen concentration was similar to pigs fed a standard corn-soybean meal diet, suggesting protein utilization was not effected by microalgae inclusion. Lum et al. (2012) found that replacing a combination of corn and soybean meal with $15 \%$ lipid-extracted algae in weanling pig diets decreased ending BW and ADG by 9 and $12 \%$, respectively. However, the particular lipid-extracted microalgae used in the Lum et al. (2012) study contained $45 \%$ ash and $19 \% \mathrm{CP}$ whereas the product used in the current study contained 19 and $35 \%$ ash and CP, respectively (Table 1). The strain of microalgae used and process by which oil is extracted can affect the nutrient profile and should be considered prior to feeding.

\section{IMPLICATIONS}

The results of the current study indicate that oil-extracted microalgae can be supplemented in growing pig diets to partially replace corn and soybean meal up to $4 \%$ without detriment to ADG, ADFI, or G:F. When applying microalgae to animal rations, the nutrient content of each strain or product should be thoroughly evaluated. Additionally, further research should be conducted to evaluate the potential of oil-extracted microalgae as a nutritive pellet binder. 


\section{ACKNOWLEDGMENTS}

This project was funded in part by the U.S. Department of Energy and Sapphire Energy,

Inc. 


\section{LITERATURE CITED}

Becker, E. W. 2007. Micro-algae as a source of protein. Biotechnol. Adv. 25:207-210.

Chisti, Y. 2007. Biodiesel from microalgae. Biotechnol. Adv. 25:294-306.

Evans, A. M., D. L. Smith, and J. S. Moritz. 2015. Effects of algae incorporation into broiler starter diet formulations on nutrient digestibility and 3 to $21 \mathrm{~d}$ bird performance. J. Appl. Poult. Res. 24:206-214.

Février, C., and B. Sève. 1975. Incorporation of a spiruline (Spirulina maxima) in swine food. Ann. Nutr. Aliment. 29:625-650.

Grau, C. R. and N. W. Klein. 1957. Sewage-grown algae as a feedstuff for chicks. Poult. Sci. 36:1046-1051.

Hintz, H. F., and H. Heitman. 1967. Sewage-grown algae as a protein supplement for swine. Anim. Prod. 9:135-140.

Isaacs, R., K. R. Roneker, M. Huntley, and X. G. Lei. 2011. A partial replacement of soybean meal by whole or defatted algal meal in diet for weanling pigs does not affect their plasma biochemical indicators. J. Anim. Sci. 89(Suppl. 1):723 (Abstr.).

Lum, K. K., K. R. Roneker, and X. G. Lei. 2012. Effects of various replacements of corn and soy by defatted microalgal meal on growth performance and biochemical status of weanling pigs. J. Anim. Sci. 90(Suppl. 3):701 (Abstr.).

NRC. 2012. Nutrient Requirements of Swine. $11^{\text {th }}$ rev. ed. Natl. Acad. Press, Washington, DC. 
Ross, E. and W. Dominy. 1990. The nutritional value of dehydrated, blue-green algae (Spirulina plantensis) for poultry. Poult. Sci. 69:794-800. 
Table 1. Nutrient composition of oil-extracted microalgae biomass

\begin{tabular}{|c|c|}
\hline Nutrient & Value \\
\hline \multicolumn{2}{|c|}{ Proximate Analysis ${ }^{1}$} \\
\hline Calories (/100 g) & 345 \\
\hline Moisture (\%) & 1.6 \\
\hline Ash (\%) & 18.9 \\
\hline Fat (by acid hydrolysis) (\%) & 8.7 \\
\hline Carbohydrates (\%) & 38.7 \\
\hline Nitrogen $(\%)$ & 5.65 \\
\hline Crude Fiber (\%) & 0.15 \\
\hline Crude Protein $^{3}(\%)$ & 35.32 \\
\hline \multicolumn{2}{|c|}{ Select Minerals ${ }^{2}(\%)$} \\
\hline Calcium & 4.05 \\
\hline Magnesium & 0.66 \\
\hline Phosphorus & 1.45 \\
\hline Potassium & 1.71 \\
\hline Sodium & 2.15 \\
\hline Sulfur & 1.40 \\
\hline \multicolumn{2}{|c|}{ Amino Acids $^{1}(\mathrm{mg} / \mathrm{g}$ of protein $)$} \\
\hline Aspartic Acid & 27.6 \\
\hline Threonine & 13.8 \\
\hline Serine & 13.7 \\
\hline Glutamic Acid & 33.5 \\
\hline Proline & 14.6 \\
\hline Glycine & 17.8 \\
\hline Alanine & 26.2 \\
\hline Valine & 16.0 \\
\hline Isoleucine & 11.9 \\
\hline Leucine & 23.7 \\
\hline Tyrosine & 10.5 \\
\hline Phenylalanine & 16.0 \\
\hline Lysine & 11.4 \\
\hline Histidine & 4.4 \\
\hline Arginine & 16.8 \\
\hline Cystine & 2.2 \\
\hline Methionine & 6.5 \\
\hline Tryptophan & 5.6 \\
\hline
\end{tabular}

${ }^{\mathrm{T}}$ Analysis by Covance Laboratories, Madison, WI

${ }^{2}$ Analysis by Sapphire Energy, San Diego, CA

${ }^{3}$ Crude protein $=\mathrm{N} \times 6.25$ 
Table 2. Composition of basal diets fed to Duroc $x$ Yorkshire-Landrace growing pigs

\begin{tabular}{|c|c|c|}
\hline Ingredient $(\%)$ & Control & $4 \%$ Algae Inclusion \\
\hline Corn & 57.05 & 56.56 \\
\hline Soybean Meal (48 \%) & 33.79 & 31.62 \\
\hline Soybean Oil & 5.97 & 5.37 \\
\hline Oil-extracted Algae & - & 4.00 \\
\hline Limestone & 1.05 & 0.67 \\
\hline Dicalcium Phosphate & 1.05 & 0.98 \\
\hline Vitamin/mineral Premix $^{1}$ & 0.25 & 0.25 \\
\hline Salt $(\mathrm{NaCl})$ & 0.22 & 0.13 \\
\hline L-Lysine $\mathrm{HCl}$ & 0.18 & 0.19 \\
\hline Sodium Bicarbonate & 0.17 & - \\
\hline DL-Methionine & 0.09 & 0.08 \\
\hline L-Threonine & 0.07 & 0.08 \\
\hline Tylan $10^{2}$ & 0.10 & 0.10 \\
\hline \multicolumn{3}{|c|}{ Calculated Nutrients ${ }^{3}$} \\
\hline ME (kcal/kg) & 3,264 & 3,264 \\
\hline Crude Protein (\%) & 20.90 & 20.90 \\
\hline Calcium (\%) & 0.70 & 0.70 \\
\hline Available Phosphorus (\%) & 0.32 & 0.32 \\
\hline Lysine $(\%)$ & 1.15 & 1.15 \\
\hline Met + Cys (\%) & 0.65 & 0.65 \\
\hline Threonine (\%) & 0.74 & 0.74 \\
\hline Tryptophan (\%) & 0.25 & 0.26 \\
\hline
\end{tabular}

${ }^{1}$ Supplied per kg of diet: manganese, $0.02 \%$; zinc $0.02 \%$; iron, $0.01 \%$; copper, $0.0025 \%$; iodine, $0.0003 \%$; selenium, $0.00003 \%$; folic acid, $0.69 \mathrm{mg}$; choline, 386mg' riboflavin, $6.61 \mathrm{mg}$; biotin, $0.03 \mathrm{mg}$; vitamin B6, $1.38 \mathrm{mg}$; niacin, $27.56 \mathrm{mg}$; pantothenic acid, $6.61 \mathrm{mg}$; thiamine, $2.20 \mathrm{mg}$; manadione, $0.83 \mathrm{mg}$; vitamin $\mathrm{B} 12,0.01 \mathrm{mg}$; vitamin E, $16.53 \mathrm{IU}$; vitamin D3, $2133 \mathrm{ICU}$; vitamin A, $7716 \mathrm{IU}$

${ }^{2}$ Tylosin phosphate $22 \mathrm{~g} / \mathrm{kg}$ (22 g/1000 kg inclusion; Elanco Animal Health, Indianapolis, IN) - For increased rate of weight gain and improved efficiency - grower feeds.

${ }^{3}$ Merck Veterinarian Manual Dietary Nutrient Requirements of Growing Pigs. Adapted from Nutrient Requirements of Swine (2012), National Research Council, National Academies Press, Washington, D.C. 
Table 3. Pellet durability of corn-soybean meal based diets supplemented with oil-extracted microalgae

\begin{tabular}{|c|c|c|c|}
\hline Treatment & PDI $^{1}(\%)$ & MPDI $^{1}(\%)$ & NHPT $^{2}(\%)$ \\
\hline Control & 51.48 & 30.30 & 21.75 \\
\hline $1 \%$ Algae inclusion & 48.67 & 28.52 & 22.70 \\
\hline $2 \%$ Algae inclusion & 51.54 & 31.53 & 25.20 \\
\hline $4 \%$ Algae inclusion & 58.68 & 42.22 & 31.80 \\
\hline
\end{tabular}

${ }^{1}$ PDI = Pellet durability index; determined by sifting $500 \mathrm{~g}$ of pellets from a treatment through a No. 5 American Society for Testing and Materials (ASTM) screen before being deposited into a Pfost tumbler. The sifted pellets were then tumbled in the container, dimensions $5 \times 12 \times 12$ in., with a $2 \times 9$ in. plate fixed diagonally along the $12 \times$ $12 \mathrm{in}$. side, for approximately $10 \mathrm{~min}$ at $50 \mathrm{rpm}$. The sample was then sifted again through the No. 5 (ASTM) mm screen, weighed, and the percentage of pellets was calculated by dividing the weight of pellets after tumbling by the weight of pellets before tumbling and then multiplying that value by 100. MPDI = Modified pellet durability index; similarly measured, with the exception of the addition of five, $13-\mathrm{mm}$ hexagonal bolts to the $500 \mathrm{~g}$ of sample in the tumbler.

${ }^{2}$ NHPT $=$ New Holmen Pellet Tester (Lignotech USA, Inc., Rothschild, WI). $100 \mathrm{~g}$ of pellets were sifted through No. 5 American Society for Testing and Materials (ASTM) screen and placed in holding chamber, blown for 30 seconds by a jet of air, then weighed, giving a direct read of pellet durability. 
Table 4. Study 1 grower pig performance (14 d)

\begin{tabular}{|c|c|c|c|}
\hline Treatment & ADG $(\mathrm{kg})$ & ADFI $(\mathrm{kg})$ & G:F \\
\hline Control & 0.956 & 1.782 & 0.537 \\
\hline $1 \%$ Algae inclusion & 0.902 & 1.829 & 0.493 \\
\hline $2 \%$ Algae inclusion & 0.864 & 1.781 & 0.485 \\
\hline $4 \%$ Algae inclusion & 1.036 & 1.999 & 0.522 \\
\hline$P-$ value & 0.2131 & 0.0641 & 0.4066 \\
\hline SEM $^{1}$ & 0.0524 & 0.0503 & 0.0229 \\
\hline
\end{tabular}

${ }^{\mathrm{I}}$ Pooled SEM $(\mathrm{n}=24)$ 
Table 5. Study 2 and 3 grower pig performance (14 d)

\begin{tabular}{|c|c|c|c|}
\hline Treatment & ADG (kg) & ADFI (kg) & $\mathrm{G}: \mathrm{F}$ \\
\hline \multicolumn{4}{|c|}{ Study 2} \\
\hline Control & 0.807 & 1.851 & 0.442 \\
\hline $4 \%$ Algae inclusion & 0.862 & 1.770 & 0.489 \\
\hline$P-$ value & 0.13 & 0.48 & 0.13 \\
\hline SEM $^{1}$ & & & \\
\hline \multicolumn{4}{|c|}{ Study 3} \\
\hline Control & 0.856 & 1.471 & 0.583 \\
\hline $4 \%$ Algae inclusion & 0.794 & 1.416 & 0.566 \\
\hline$P-$ value & 0.1817 & 0.7069 & 0.7347 \\
\hline SEM $^{1}$ & 0.0270 & 0.0965 & 0.0335 \\
\hline
\end{tabular}

${ }^{1}$ Pooled SEM $(\mathrm{n}=20)$ 


\title{
CHAPTER 5
}

Performance and carcass characteristics of two commercial turkey hen strains and a test product turkey hen strain reared from d 1-125

\author{
K.L. Foltz ${ }^{*}$ and J.S. Moritz *,1 \\ "Division of Animal and Nutritional Sciences, West Virginia University, Morgantown, WV 26506
}

Primary audience: Geneticists, Nutritionists, Researchers

${ }^{1}$ Corresponding author: jsmoritz@mail.wvu.edu 


\section{SUMMARY}

An 18-wk study was conducted to compare the growth and carcass characteristics of two commercial turkey hen strains, Nicholas 700 and Hybrid Converter, and a test product strain (Super Select; SS). The effect of an elevated nutrient (EN) diet on SS hens was examined for feathering. Additionally, lysine oxidation via lysine $\alpha$-ketoglutarate reductase (LKR) was assessed on d 125 for genetic comparisons. Live weight gain (LWG) was highest for Hybrid hens during wk 1-4, and highest for Nicholas and SS hens from wk 13-16 $(P<0.05)$. Mortality corrected feed conversion ratio (FCR) was improved for Nicholas and Hybrid hens compared to SS hens from wk 1-4, but all performance variables were similar at $18 \mathrm{wk}$. Hot carcass breast and fat pad yield were similar among all treatments, and chilled carcass breast yield was numerically highest for SS hens. The EN diet improved feathering of SS on d 112, but not d 56 . Liver LKR activity was relatively low and not different among strains, and may not have differed in part due to lack of performance differences among treatments.

Key words: turkey, hen, performance, carcass, feathering, lysine, lysine $\alpha$-ketoglutarate reductase 


\section{DESCRIPTION OF PROBLEM}

Growth and efficiency of modern turkey strains are far superior to their 1960 counterparts. Improvements can be contributed to nutrition, management, and disease prevention, in part, but are largely associated with genetic selection [1-3]. Havenstein et al. [4] determined that the body weight of 112-d-old toms and hens have increased by 186 and $164 \mathrm{~g} / \mathrm{yr}$, respectively, from 1966 to 2003, while the time to reach market weight was halved. Along with advancements in performance, carcass characteristics and yields of turkey strains have changed $[5,6]$. Currently, the two most established turkey strains in the U.S. are Nicholas 700 [7] and Hybrid Converter [8]. A comprehensive comparison of performance and carcass characteristics of these two strains in hen turkeys has not been reported in two decades [9].

A test product turkey strain (Super Select; SS) was examined in the current study, which had feathering complications. Lack of feather cover leaves skin susceptible to scratching and breaking, which could lead to diseases such as cellulitis and breast blisters that may ultimately lead to condemnation at the processing plant [10]. Sikur et al. [11] found that increasing dietary ME and amino acid density improved feathering of a slow-feathering variety of female turkeys at $\mathrm{d} 32$ and 56. Zinc is a cofactor for keratin and epithelial cell formation, thus it may be beneficial for feathering and skin elasticity. Additionally, slow-feathering turkeys have decreased zinc absorption and metabolism [12]. The biotin requirement of turkeys is higher than that of chickens [13]. Biotin deficiencies in poultry lead to decreased feed intake, foot pad lesions, and broken feathering [14].

Lysine is the second-limiting amino acid for poultry, and is the basis for formulating digestible amino acids in diets. The majority of lysine oxidation occurs via the lysine $\alpha$ ketoglutarate reductase (LKR) pathway $[15,16]$. Improvements in lysine efficiency would likely 
be associated with increased feed efficiency and muscle assembly. Therefore, it is plausible that feed conversion ratio (FCR) may be inversely related to LKR activity. West et al. [17] found that Hybrid strain toms had lower LKR activity (d 1-136) than Nicholas strain toms, and also had a lower FCR during this growth period.

The objective of the current study was to assess the effects of three genetic strains of hen turkeys on performance and carcass characteristics, as well as to determine associations between FCR and LKR induced lysine oxidation. The second objective was to determine the effect of an elevated nutrient (EN) diet on feathering of SS hens.

\section{MATERIALS AND METHODS}

\section{Experimental Design}

The study consisted of three genetic strains of hen turkeys and two dietary treatments. The strains of turkeys used were commercially available Nicholas 700 (N700) and Hybrid Converter [7, 8], and a test product strain (Super Select). Super Select (SS) hens were additionally fed an elevated nutrient (EN) diet to evaluate its effect on feathering properties. Therefore, the three strains of hen turkeys were fed a commercial-type basal diet (Basal) and a group of SS hens were fed an EN diet, for a total of four treatments. Due to experimental design, treatments were evaluated based on pre-planned contrasts (N700 vs Hybrid vs SS (Basal); SS (Basal) vs SS (EN)).

\section{Birds and Management}

All animal protocols were in accordance with the West Virginia University Institutional Animal Care and Usage Committee. Hen turkeys were reared at the WVU Reymann Memorial Turkey Research facility in Wardensville, WV, equipped with 16 (6.1 x $5.2 \mathrm{~m})$ pens. The 
research facility is designed to mimic a commercial barn, with negative-pressure ventilation, attic vents, and radiant brooders.

A total of 2,240 1-d-old hen turkey poults (560 Nicholas 700 and Hybrid Converter; 1,120 Aviagen Super Select) were obtained from a commercial hatchery [18]. Hen poults were placed on fresh pine shavings at a density of 140 poults per pen $\left(0.23 \mathrm{~m}^{2} /\right.$ poult $)$. Treatment allotment was blocked by location within the facility, allowing for four replicate pens per turkey strain/feed combination. Pens were equipped with plasson bell drinkers [19] and an augured feed pan system with an adapted hopper [20] to provide ad libitum access to feed and water. All feed was manually added to hoppers in each pen throughout the study. Supplemental feeders and waterers were utilized for the first five d post-hatch. On $\mathrm{d} 27$, poults were wing banded and sprayed with a food coloring/soap solution, with colors corresponding to each treatment for identification. Industry temperature and lighting guidelines were followed as prescribed by Aviagen [7].

\section{Diets and Feed Manufacture}

Diets were formulated on a digestible amino acid basis to meet or exceed Aviagen recommendations for Nicholas females [7]. Hard red winter wheat and poultry meal inclusions were held constant throughout the study at 20 and $10 \%$, respectively. An 8-phase feeding program was used for the basal dietary treatment (Table 1) and a 5-phase program was utilized for the EN dietary treatment (Table 2). In the EN dietary treatment, digestible methionine and digestible methionine + cystine were increased by 20 and $15 \%$, respectively, compared to the basal diet. Additionally, Biotin $100(220 \mathrm{mg} / \mathrm{kg})$ [21] was included at $0.496 \mathrm{~kg}$ per MT and 
Availa-Zn 120 [22] was included at $0.034 \%$ to supply an additional $39.94 \mathrm{mg}$ of $\mathrm{Zn}$ per kg of feed from a Zn-AA complex.

All feed was manufactured at the West Virginia University pilot feed mill. Diets were batched in a 0.91-MT vertical screw mixer [23], with $3 \%$ of dietary fat added at the mixer and the remainder added post-pelleting. Diets were steam conditioned at $82.2^{\circ} \mathrm{C}$ through a $1.3 \mathrm{x}$ 0.31 short-term $(10 \mathrm{sec})$ conditioning barrel and pelleted through a $3.8 \times 44.5$ effective thickness die powered by a 40-HP California pellet mill rated for $1 \mathrm{ton} / \mathrm{hr}$ [24]. Complete diet samples were retained for analyzed nutrient concentrations (Tables 1 and 2) [25]. Diets were fed as a crumble from d 1-27 and as intact pellets thereafter.

\section{Poult Performance}

Hen turkeys were weighed as a pen on $\mathrm{d} 1$, and individually weighed every 4 weeks (d $28,56,84,112$, and 125) throughout the duration of the study. Individual weights were used to determine coefficient of variation (CV) of each strain due its potential to negatively impact processing plant efficiency. Feed disappearance was recorded on days that individual weighing took place. Mortalities and subsequent weights were recorded daily. These data were used to determine feed intake (FI) per bird, live weight gain (LWG) per bird, mortality percentage, and mortality corrected feed conversion ratio (FCR) during each growth period. On d 56 and 112, 20 poults per pen were selected for feather scoring analysis. A single, trained individual performed all scoring. A 5 -point likert scale was used $(0=$ no feather coverage to $5=$ full coverage) to evaluate areas of concern. On d 56, areas of concern included the dorsal, thigh, and keel regions. On $\mathrm{d} 112$, the neck region was ranked in place of the keel. 


\section{Carcass Characteristics and LKR Activity}

On d 125, two poults per pen were randomly selected and weighed for boneless/skinless (B/S) hot breast and abdominal fat pad extraction to determine hot breast and fat pad yields. Approximately $5 \mathrm{~g}$ of the left lobe of the liver was excised from one bird per pen for lysine- $\alpha$ ketoglutarate reductase (LKR) analysis as described by Blemings et al. [15]. Briefly, $0.1 \mathrm{~g}$ of each liver was diced and homogenized in $\mathrm{H}$ medium $(220 \mathrm{mmol} / \mathrm{L}$ mannitol, $70 \mathrm{mmol} / \mathrm{L}$ sucrose, $5 \mathrm{mmol} / \mathrm{L}$ HEPES, $1 \mathrm{mmol} / \mathrm{L}$ EGTA, $\mathrm{pH}$ 7.4) containing $0.5 \mathrm{~g} / \mathrm{L}$ bovine serum albumin and 5 $\mathrm{mmol} / \mathrm{L} 2$ 2-mercaptoethanol using a Potter-Elvehjem glass homogenizer. A $25 \%$ (w/v) (i.e. 1:3) homogenate was prepared. Lysine $\alpha$-ketoglutarate reductase activity was determined by measuring lysine-dependent oxidation of NADPH using a Beckman Coulter DU-640 spectrophotometer [25] set at wavelength $340 \mathrm{~nm}$ in LKR medium (150 mmol/L HEPES, 135 $\mathrm{mmol} / \mathrm{L}$ mannitol, $45 \mathrm{mmol} / \mathrm{L}$ sucrose, $5 \mathrm{mmol} / \mathrm{L}$ 2-mercaptoethanol, $0.5 \mathrm{~g} / \mathrm{L}$ bovine serum albumin, $0.25 \mathrm{mmol} / \mathrm{L}$ NADPH, $15 \mathrm{mmol} / \mathrm{L} \alpha$-ketoglutarate, $0.5 \mathrm{~g} / \mathrm{L}$ Triton-X, $\mathrm{pH} 7.8$ ) with or without lysine. All samples were analyzed in duplicate and reactions started with the addition of lysine. Liberation of NADPH was measured for a 3-minute time lapse using a LineweaverBurke kinetics program.

On d 126, remaining hen turkeys were transported to a commercial processing plant [27]. Fifty birds per treatment were randomly selected at the plant for descriptive chilled carcass evaluation.

\section{Statistical Analysis}

Hen turkey performance, hot carcass yields, and LKR activity data were analyzed by oneway ANOVA using the PROC GLM procedure of SAS [28]. As aforementioned, pre-planned 
contrasts were evaluated to compare the three genetic strains of turkeys fed the basal diet and SS hens fed the basal diet versus the EN diet. Significance was considered at $\alpha \leq 0.05$ and trends were considered when $0.05<\alpha \leq 0.08$. Post hoc comparisons were made using Fisher's least significant difference (LSD) test. Feather scoring and chilled carcass characteristics will be presented as descriptive data.

\section{RESULTS AND DISCUSSION}

\section{Poult Performance}

\section{Strain Comparison}

Hen turkey performance data for each growth phase are depicted in Tables 3 and 4. Live weight gain per bird was $93 \mathrm{~g}$ higher $(P<0.05)$ for Hybrid hens compared to SS hens fed the basal diet for the first $4 \mathrm{wk}(\mathrm{d} 1-27)$. Nicholas 700 and Hybrid strains had lower FCR $(P<0.01)$ than the SS (basal) treatment during this growth period. Similar weight gain results were observed in toms by Roberson et al. [29], in which Hybrid toms had higher BW than Nicholas toms at $6 \mathrm{wk}$ of age ( $2.81 \mathrm{vs} 2.58 \mathrm{~kg})$. The authors also found that mortality adjusted FCR was statistically similar between the two strains, yet Hybrid toms had a numerically lower adjusted FCR (1.35 vs 1.40$)$. In the current study, from wk 5-8 (d 56-83), mortality was 2.40 percentage points higher $(P<0.05)$ for Hybrid hens than N700 and SS (basal) hens.

Feed intake/bird and LWG/bird were superior $(P<0.05)$ for the SS (basal) and N700 treatments compared to the hybrid treatment from $\mathrm{d}$ 84-111. These data are in partial agreement with previous authors $[9,29]$. Barbour and Lilburn [9] reported that BW of Nicholas hens were higher than Hybrid hens at $110 \mathrm{~d}$ of age, but Hybrid were generally heavier during most growth 
periods and overall. In toms, Roberson et al. [29] found that BW was similar between the two strains with Nicholas toms having a lower adjusted FCR (2.19 vs 2.25$)$ at 16 wk. For the overall growth period (d 1-125), there were no significant differences in performance variables measured (Table 5). However, there was a trend for increased FI $(P=0.070)$, and a numerical decrease in FCR $(P=0.3569)$ for SS hens compared to Hybrid and N700 hens. It should be noted that mortality was high compared to commercial standards, but this was due to aggressive culling to minimize outliers. Relative to the circa 1992 commercial hens used by Barbour and Lilburn [6], Nicholas and Hybrid hens used in the current study were 1.53 and $1.10 \mathrm{~kg}$ heavier at $125 \mathrm{~d}$ than the 1992 hens at $131 \mathrm{~d}$. This equates to a 0.8 and $0.5 \%$ increase in BW of Nicholas and Hybrid hens, respectively, per year during this time period and age. Interestingly, coefficient of variation (CV) for BW was similar for all strains during each growth phase.

\section{SS (Basal) vs SS (EN)}

There was a trend $(P=0.061)$ for increased FI/bird for the SS (basal) treatment relative to the SS (EN) treatment from d 28-55, yet FI/bird from d 56-83 was significantly higher $(P<0.05)$ for the SS (EN) treatment. During the d 28-55 growth period, the ME of both diets were similar, but from d 56-83 the ME of the basal diets were 99 and $150 \mathrm{kcal} / \mathrm{kg}$ higher than the EN diet. Therefore, poults fed the EN diet likely compensated by consuming more feed. Super Select hens fed the EN diet had a 0.181 higher FCR $(P<0.05)$ than their counterparts fed the basal diet from d 84-111, which may be a result of lower ME and higher CP in the EN diet. Waldroup et al. [30] determined that FCR was improved in toms at 12 and $18 \mathrm{wk}$ when feed change intervals were every 4 wks rather than 3 wks. This was not seen in the current study. Similar to the current study, Leeson and Caston [31] observed that BW of Nicholas hens fed a high CP diet compared to a conventional U.S. diet were similar from d 28 to 105. From d 112-125, there were 
small but significant differences for mortality, with SS hens consuming the EN diet being 0.65 percentage points higher than those fed the basal diet $(P<0.05)$. Super Select hens in general (basal and EN) had lower BW during the first half of the study, but had the highest numerical BW at $\mathrm{d} 125(P=0.077)$ suggesting they may be desirable for the heavy hen market.

\section{Feather Scoring}

Overall, feather coverage at d 56 was high for all strains (Table 6). The thigh region was the area of concern with the least amount of feathering. In this region and overall, Hybrid hens had the best feather coverage. The EN diet did not appear to improve feathering at this time point. On $\mathrm{d} 112$, the neck region generally had the lowest feather scores. The EN diet improved feather score in this region (4.2 vs 3.5) relative to the SS (basal) treatment and overall (4.7 vs 4.5). Hybrid hens still had the highest overall feather score, but the SS (EN) treatment was comparable (4.8 vs 4.7$)$.

\section{Carcass Characteristics and LKR Activity}

At $18 \mathrm{wk}$ (d 125), hot breast and fat pad yields were similar among all treatments (Table 7). Barbour and Lilburn [9] observed that the Pectoralis major yield of Nicholas and Hybrid hens was similar, but abdominal fat pad yields were higher from d 70-145 for Nicholas hens.

No significant differences were observed for LKR activity $(P>0.1)$. Numerically, N700 hens had the lowest (not detectable) LKR activity and Hybrid hens had the highest (2.06 x $10^{-11}$ $\mathrm{mol} / \mathrm{g}$ liver * min). The LKR activity of the SS (EN) treatment was numerically higher than the SS (basal) treatment as expected due to increased amino acid density of the EN diet. Wang and Nesheim [32] determined that genetic differences in lysine metabolism could be observed by LKR content in chicks. Wang et al. [33] suggested that lysine oxidation was dependent on the 
lysine pool in chicks fed low dietary lysine, but LKR was indicative of lysine oxidation when chicks were supplied sufficient or high levels of dietary lysine. In the current study with turkey hens, only relative differences were seen though dietary lysine was adequate. In the current study, there were no apparent relationships between LKR activity and FCR. These data are contradictory to results reported by West et al. [17], in which Hybrid toms had lower LKR activity and improved FCR compared to Nicholas toms. Therefore, it is possible that associations could have been observed if there were differences in FCR at the time of sampling (d 125) in the current study.

Descriptive carcass yield data are presented in Table 8. These data represent 50 randomly selected birds from each treatment at the processing plant. Among hens fed the basal diet, SS had the highest front half, tender w/ strap, and boneless/skinless (B/S) breast yields (61.19, 6.37, and $23.34 \%$, respectively). Hybrid hens had higher hind half, breast skin, drum, and $\mathrm{B} / \mathrm{S}$ thigh meat yield $(39.79,6.69,12.02$, and $10.64 \%$, respectively) compared to $\mathrm{N} 700$ and SS. Super Select hens fed the EN diet had higher carcass weight omitting giblets (WOG) than those fed the basal diet, while yields were generally similar. 


\section{CONCLUSIONS AND APPLICATIONS}

1) Hybrid hens had a larger LWG than SS hens during the first 4 wk of growth, but Nicholas and SS hens had superior LWG between d 84-111, and BW was similar among all three strains at $18 \mathrm{wk}$.

2) Within this study, increasing dietary digestible methionine and cystine, along with increased biotin, zinc, and diet interval changes (4 vs 2 wk) improved feathering of SS hens compared to those fed the basal diet at $112 \mathrm{~d}$.

3) Lysine $\alpha$-ketoglutarate reductase activity may be correlated to FCR when there are performance differences and should be evaluated in future studies. 


\section{REFERENCES AND NOTES}

1. Sherwood, D. H. 1977. Modern broiler feeds and strains: What two decades of improvement have done. Feedstuffs 49:70.

2. Havenstein, G. B., P. R. Ferket, J. L. Grimes, M. A. Qureshi, and K. E. Nestor. 2004. Performance of 1966 vs. 2003-type turkeys when fed representative 1966 and 2003 turkey diets. Proc. World's Poult. Congr., Istanbul, Turkey. WPSA, Izmir, Turkey.

3. Nestor, K. E., M. G. McCartney, and N. Bachev. 1969. Relative contributions of genetics and environment to turkey improvement. Poult. Sci. 43:739-744.

4. Havenstein, G. B., P. R. Ferket, J. L. Grimes, M. A. Qureshi, and K. E. Nestor. 2007. Comparison of the performance of 1966- versus 2003-type turkeys when fed representative 1966 and 2003 turkey diets: Growth rate, livability, and feed conversion. Poult. Sci. 86:232-240.

5. Lilburn, M. S. and K. E. Nestor. 1991. Body weight and carcass development in different lines of turkeys. Poult. Sci. 70:2223-2231.

6. Larsen, J. E., R. L. Adams, I. C. Peng, and W. J. Stadelman. 1986. Growth, feed conversions, and yields of turkey parts of three strains of hen turkeys as influenced by age. Poult. Sci. 65:2076-2081.

7. Aviagen Turkeys, Inc., Lewisburg, WV.

8. Hybrid Turkeys, Kitchener, ON, Canada.

9. Barbour, G. W. and M. S. Lilburn. 1995. Characterization of carcass development from 14 to 145 days of age in turkey hens from two strains. Poult. Sci. 74:1650-1658.

10. Elfadil, A. A., J. P. Vaillancourt, and A. H. Meek. 1996. Impact of stocking density, breed, and feathering on the prevalence of abdominal skin scratches in broiler chickens. Avian Dis. 40:546-552.

11. Sikur, V. R., F. E. Robinson, D. R. Korver, R. A. Renema, and M. J. Zuidhoft. 2004. Effects of nutrient density on growth and carcass traits in fast- and slow-feathering female turkeys. Poult. Sci. 83:1507-1517.

12. Zakrzewska, E. I., and T. F. Savage. 1997. Inhibited feathering: A new dominant sexlinked gene in the turkey. J. Hered. 88:238-247. 
13. National Research Council, (1994). Nutrient Requirements of Poultry. 9th Rev. Ed. NASNRC, Washington, D.C.

14. Harms, R. H. and C. F. Simpson. 1975. Biotin deficiency as a possible cause of swelling and ulceration of foot pads. Poult. Sci. 54:1711-1713.

15. Blemings, K. P., T. D. Crenshaw, R. W. Swick, and N. J. Benevenga. 1994. Lysine- $\alpha-$ ketoglutarate reductase and saccharopine dehydrogenase are located only in the mitochondrial matrix in rat liver. J. Nutr. 124:1215-1221.

16. Manangi, M. K., S. F. A. Hoewing, J. G. Engels, A. D. Higgins, J. Killefer, M. E. Wilson, and K. P. Blemings. 2005. Lysine $\alpha$-ketoglutarate reductase and lysine oxidation are distributed in the extrahepatic tissues of chickens. J. Nutr. 135:81-85.

17. West, B. N., K. G. S. Lilly, K. R. Beaman, L. K. Shires, S. A. Loop, and J. S. Moritz. 2010. The effects of strain and dietary phosphorus level on large tom turkey performance. Poult. Sci. Vol. 89 (E - Suppl. 1): W267.

18. Cargill, Inc., Harrisonburg, VA.

19. Plasson Livestock, Menashe, Israel.

20. Chore-Time Poultry Production Systems, Milford, IN.

21. Nutra Blend, LLC., Neosho, MO.

22. Zinpro Corporation, Eden Prairie, MN.

23. MFP Vertical Mixer, Easy Automation Inc., Welcome, MN.

24. Master Model Pellet Mill, California Pellet Mills Company, Crawfordsville, IN.

25. New Jersey Feed Labs Inc., Trenton, NJ.

26. Beckman Coulter, Inc., Brea, CA.

27. Virginia Poultry Growers Cooperative, Hinton, VA. 
28. SAS Institute. 2013. The SAS System for Windows 2013. Release 9.3. SAS Inst. Inc., Cary, NC.

29. Roberson, K. D., A. P. Rahn, R. J. Balander, M. W. Orth, D. M. Smith, B. L. Booren, A. M. Booren, W. N. Osburn, and R. M. Fulton. 2003. Evaluation of the growth potential, carcass components and meat quality characteristics of three commercial strains of tom turkeys. J. Appl. Poult. Res. 12:229-236.

30. Waldroup, P. W., J. A. England, A. L. Waldroup, and N. B. Anthony. 1997. Response of two strains of large white male turkeys to amino acid levels when diets are changed at three- or four-week intervals. Poult. Sci. 76:1543-1555.

31. Leeson, S. and L. J. Caston. 1991. Response of two strains of turkey hens to various protein and energy feeding programs. Poult. Sci. 70:1739-1747.

32. Wang, S-H. and M. C. Nesheim. 1972. Degradation of lysine in chicks. J. Nutr. 102:583.

33. Wang, S-H., L. O. Crosby, and M. C. Nesheim. 1973. The effect of dietary excesses of lysine and arginine on the degradation of lysine by chicks. J. Nutr. 103:384. 
Table 1. Composition (\%) of basal diets fed to commercial turkey hens ${ }^{1}$

\begin{tabular}{|c|c|c|c|c|c|c|c|c|}
\hline Ingredient & D 1-27 & D 28-41 & D $42-55$ & D 56-69 & D 70-83 & D 84-97 & D 98-111 & D 112-125 \\
\hline Corn & 20.67 & 27.88 & 35.47 & 40.77 & 44.09 & 46.97 & 47.39 & 48.77 \\
\hline Wheat & 20.00 & 20.00 & 20.00 & 20.00 & 20.00 & 20.00 & 20.00 & 20.00 \\
\hline Soybean meal (48 \%) & 37.02 & 29.92 & 23.72 & 18.40 & 15.78 & 12.43 & 10.91 & 9.19 \\
\hline Poultry meal & 10.00 & 10.00 & 10.00 & 10.00 & 10.00 & 10.00 & 10.00 & 10.00 \\
\hline AV blend fat $^{2}$ & 6.72 & 6.86 & 6.22 & 6.85 & 6.89 & 7.32 & 8.80 & 9.36 \\
\hline Monocalcium Phosphate & 2.16 & 1.87 & 1.57 & 1.36 & 1.04 & 1.11 & 0.89 & 0.66 \\
\hline Limestone & 2.01 & 1.88 & 1.67 & 1.52 & 1.30 & 1.32 & 1.21 & 1.02 \\
\hline L-Lysine $\mathrm{HCl}$ & 0.42 & 0.38 & 0.49 & 0.32 & 0.23 & 0.22 & 0.18 & 0.11 \\
\hline DL-Methionine & 0.34 & 0.58 & 0.25 & 0.19 & 0.14 & 0.10 & 0.11 & 0.38 \\
\hline Salt $(\mathrm{NaCl})$ & 0.29 & 0.29 & 0.27 & 0.27 & 0.24 & 0.24 & 0.24 & 0.24 \\
\hline L-Threonine & 0.09 & 0.07 & 0.07 & 0.05 & 0.02 & 0.01 & 0.00 & 0.00 \\
\hline Choline chloride & 0.02 & 0.02 & 0.02 & 0.02 & 0.02 & 0.02 & 0.02 & 0.02 \\
\hline Poultry premix ${ }^{3}$ & 0.25 & 0.25 & 0.25 & 0.25 & 0.25 & 0.25 & 0.25 & 0.25 \\
\hline \multicolumn{9}{|l|}{ Calculated nutrient analysis } \\
\hline $\mathrm{ME}(\mathrm{kcal} / \mathrm{kg})$ & 3,026 & 3,105 & 3,156 & 3,255 & 3,306 & 3,357 & 3,456 & 3,507 \\
\hline Crude protein $(\%)$ & 29.35 & 26.70 & 24.09 & 21.76 & 20.61 & 19.19 & 18.46 & 17.95 \\
\hline Dig Lysine (\%) & 1.73 & 1.53 & 1.47 & 1.21 & 1.08 & 0.99 & 0.92 & 0.82 \\
\hline Dig Methionine (\%) & 0.72 & 0.92 & 0.57 & 0.49 & 0.43 & 0.39 & 0.39 & 0.64 \\
\hline Dig Met + Cys (\%) & 1.12 & 1.29 & 0.92 & 0.82 & 0.75 & 0.69 & 0.68 & 0.93 \\
\hline Dig Threonine (\%) & 1.01 & 0.90 & 0.82 & 0.73 & 0.67 & 0.61 & 0.58 & 0.55 \\
\hline Calcium (\%) & 1.49 & 1.38 & 1.24 & 1.14 & 1.00 & 1.01 & 0.93 & 0.82 \\
\hline Av. Phosphorus (\%) & 0.76 & 0.69 & 0.62 & 0.57 & 0.50 & 0.51 & 0.46 & 0.41 \\
\hline \multicolumn{9}{|l|}{ Analyzed nutrient analysis ${ }^{4}$} \\
\hline Crude protein $(\%)$ & 27.61 & 24.50 & 22.57 & 19.73 & 17.97 & 17.45 & 16.74 & 16.17 \\
\hline Crude fat $(\%)$ & 8.68 & 8.35 & 7.73 & 9.19 & 10.53 & 10.48 & 11.25 & 13.13 \\
\hline Lysine (\%) & 1.76 & 1.47 & 1.40 & 1.18 & 1.13 & 0.97 & 0.94 & 0.76 \\
\hline Methionine (\%) & 0.64 & 0.70 & 0.42 & 0.40 & 0.34 & 0.31 & 0.29 & 0.53 \\
\hline Cystine (\%) & 0.43 & 0.42 & 0.40 & 0.38 & 0.36 & 0.33 & 0.30 & 0.32 \\
\hline
\end{tabular}

${ }^{1}$ Formulation meets or exceeds nutrients as specified by Aviagen Nicholas female turkey recommendations (Aviagen Turkeys, Inc., Lewisburg, WV).

${ }^{2}$ Animal vegetable blend

${ }^{3}$ Supplied per kilogram of diet: $0.02 \%$ manganese; $\mathbf{0 . 0 2 \%}$ zinc; $0.01 \%$ iron; $0.0025 \%$ copper; $0.0003 \%$ iodine; $0.00003 \%$ selenium; 0.69 mg of folic acid; 386 mg of choline; 6.61 $\mathrm{mg}$ of riboflavin; $\mathbf{0 . 0 3} \mathbf{~ m g}$ of biotin; $1.38 \mathrm{mg}$ of vitamin $\mathrm{B}_{6} ; 27.56 \mathrm{mg}$ of niacin; $6.61 \mathrm{mg}$ of pantothenic acid; $2.20 \mathrm{mg}$ of thiamine; $0.83 \mathrm{mg}$ of menadione; $0.01 \mathrm{mg}$ of vitamin $\mathrm{B}_{12}$; 16.53 IU of vitamin E; 2,133 ICU of vitamin $\mathrm{D}_{3}$; and 7,716 IU of vitamin A

${ }^{4}$ Analyzed in duplicate at commercial laboratory (New Jersey Feed Labs Inc., Trenton, NJ). 
Table 2. Composition (\%) of elevated nutrient diets fed to commercial turkey hens ${ }^{1}$

\begin{tabular}{|c|c|c|c|c|c|}
\hline Ingredient & D 1-27 & D 28-55 & D 56-83 & D 84-111 & D 112-125 \\
\hline Corn & 20.25 & 27.42 & 35.11 & 40.44 & 43.87 \\
\hline Wheat & 20.00 & 20.00 & 20.00 & 20.00 & 20.00 \\
\hline Soybean meal (48 \%) & 37.06 & 29.95 & 23.75 & 18.43 & 15.80 \\
\hline Poultry meal & 10.00 & 10.00 & 10.00 & 10.00 & 10.00 \\
\hline AV blend fat $^{2}$ & 6.85 & 7.00 & 6.33 & 6.94 & 6.97 \\
\hline Monocalcium Phosphate & 2.16 & 1.87 & 1.57 & 1.36 & 1.04 \\
\hline Limestone & 2.01 & 1.88 & 1.67 & 1.52 & 1.30 \\
\hline L-Lysine $\mathrm{HCl}$ & 0.42 & 0.38 & 0.49 & 0.32 & 0.23 \\
\hline DL-Methionine & 0.52 & 0.78 & 0.39 & 0.32 & 0.25 \\
\hline Salt $(\mathrm{NaCl})$ & 0.29 & 0.29 & 0.27 & 0.27 & 0.24 \\
\hline L-Threonine & 0.09 & 0.07 & 0.07 & 0.05 & 0.02 \\
\hline Choline chloride & 0.02 & 0.02 & 0.02 & 0.02 & 0.02 \\
\hline Poultry premix ${ }^{3}$ & 0.25 & 0.25 & 0.25 & 0.25 & 0.25 \\
\hline Biotin 100 & 0.05 & 0.05 & 0.05 & 0.05 & 0.05 \\
\hline Availa-Zn $120^{5}$ & 0.034 & 0.034 & 0.034 & 0.034 & 0.034 \\
\hline \multicolumn{6}{|l|}{ Calculated nutrient analysis } \\
\hline ME (kcal/kg) & 3,026 & 3,105 & 3,156 & 3,255 & 3,306 \\
\hline Crude protein $(\%)$ & 29.51 & 26.88 & 24.09 & 21.87 & 20.72 \\
\hline Dig Lysine (\%) & 1.73 & 1.53 & 1.47 & 1.21 & 1.08 \\
\hline Dig Methionine (\%) & 0.89 & 1.11 & 0.71 & 0.62 & 0.55 \\
\hline Dig Met + Cys $(\%)$ & 1.29 & 1.48 & 1.06 & 0.94 & 0.86 \\
\hline Dig Threonine (\%) & 1.01 & 0.90 & 0.82 & 0.73 & 0.67 \\
\hline Calcium (\%) & 1.49 & 1.38 & 1.24 & 1.14 & 1.00 \\
\hline Av. Phosphorus (\%) & 0.76 & 0.69 & 0.62 & 0.57 & 0.50 \\
\hline \multicolumn{6}{|l|}{ Analyzed nutrient analysis ${ }^{6}$} \\
\hline Crude protein $(\%)$ & 28.98 & 24.05 & 21.83 & 19.93 & 17.80 \\
\hline Crude fat $(\%)$ & 5.91 & 8.79 & 8.72 & 9.84 & 9.99 \\
\hline Lysine (\%) & 1.72 & 1.46 & 1.40 & 1.15 & 1.03 \\
\hline Methionine (\%) & 0.74 & 0.91 & 0.59 & 0.52 & 0.42 \\
\hline Cystine (\%) & 0.46 & 0.40 & 0.37 & 0.34 & 0.33 \\
\hline
\end{tabular}

\footnotetext{
${ }^{1}$ Formulation meets or exceeds nutrients as specified by Aviagen Nicholas female turkey recommendations (Aviagen Turkeys, Inc., Lewisburg, WV).

${ }^{2}$ Animal vegetable blend.

${ }^{3}$ Supplied per kilogram of diet: $0.02 \%$ manganese; $0.02 \%$ zinc; $0.01 \%$ iron; $0.0025 \%$ copper; $0.0003 \%$ iodine; $0.00003 \%$ selenium; $0.69 \mathrm{mg}$ of folic acid; $386 \mathrm{mg}$ of choline; $6.61 \mathrm{mg}$ of riboflavin; $0.03 \mathrm{mg}$ of biotin; $1.38 \mathrm{mg}$ of vitamin $\mathrm{B}_{6} ; 27.56 \mathrm{mg}$ of niacin; $6.61 \mathrm{mg}$ of pantothenic acid; $2.20 \mathrm{mg}$ of thiamine; $0.83 \mathrm{mg}$ of menadione; $0.01 \mathrm{mg}$ of vitamin $\mathrm{B}_{12} ; 16.53 \mathrm{IU}$ of vitamin $\mathrm{E}$; 2,133 ICU of vitamin $\mathrm{D}_{3}$; and 7,716 IU of vitamin A.

${ }^{4}$ Biotin 100 (Nutra Blend LLC., Neosho, MO) included at $0.496 \mathrm{~kg} / \mathrm{MT}=0.1402 \mathrm{mg} / \mathrm{kg}$ total.

${ }^{5}$ Total Zn incorporated in elevated nutrient diet $=\mathbf{2 3 9 . 9 4} \mathbf{~ m g} / \mathbf{k g}$ or $\mathbf{0 . 0 2 4} \% ; 200 \mathrm{mg} / \mathrm{kg}$ from poultry premix; $39.94 \mathrm{mg} / \mathrm{kg}$ from Availa-Zn 120 (Zinpro Corporation, Eden Prairie, MN).

${ }^{6}$ Analyzed in duplicate at commercial laboratory (New Jersey Feed Labs Inc., Trenton, NJ).
} 
Table 3. Hen turkey performance from d 1-83

\begin{tabular}{|c|c|c|c|c|c|c|c|c|c|c|c|c|c|c|c|}
\hline & & \multicolumn{4}{|c|}{ d 1-27 } & \multicolumn{5}{|c|}{ d 28-55 } & \multicolumn{5}{|c|}{ d 56-83 } \\
\hline Diet & Strain $^{1}$ & $\begin{array}{l}\text { FI/bird } \\
\quad(\mathbf{k g})\end{array}$ & $\begin{array}{c}\text { LWG/bird } \\
{ }_{(\mathbf{k g})}\end{array}$ & $\mathrm{FCR}^{3}$ & $\begin{array}{c}\text { Mort }^{2} \\
(\%)\end{array}$ & $\begin{array}{l}\text { FI/bird }{ }^{2} \\
\quad(\mathrm{~kg})\end{array}$ & $\begin{array}{c}\text { LWG/bird } \\
(\mathrm{kg})\end{array}$ & $\mathbf{F C R}^{3}$ & $\begin{array}{c}\text { Mort }^{2} \\
(\%)\end{array}$ & $\begin{array}{c}\text { CV for } \\
\text { EBW }^{2} \\
(\%)\end{array}$ & $\begin{array}{l}\text { FI/bird }{ }^{2} \\
\quad(\mathbf{k g})\end{array}$ & $\begin{array}{c}\text { LWG/bird } \\
(\mathrm{kg})\end{array}$ & $\mathrm{FCR}^{3}$ & $\begin{array}{c}\operatorname{Mort}^{2} \\
(\%)\end{array}$ & $\begin{array}{c}\text { CV for } \\
\text { EBW }^{2} \\
(\%) \\
\end{array}$ \\
\hline \multirow{3}{*}{ Basal } & SS & 1.404 & $0.806^{\mathrm{c}, \mathrm{y}}$ & $1.731^{\mathrm{a}, \mathrm{x}}$ & 1.964 & 4.871 & 2.629 & 1.848 & 2.00 & 9.932 & $8.794^{b}$ & $3.395^{\mathrm{ab}}$ & 2.550 & $2.61^{\mathrm{y}}$ & 9.050 \\
\hline & N700 & 1.377 & $0.848^{\mathrm{bc}, \mathrm{xy}}$ & $1.621^{\mathrm{bc}, \mathrm{y}}$ & 1.071 & 4.721 & 2.537 & 1.851 & 1.99 & 9.185 & $8.651^{\mathrm{bc}}$ & $3.289^{b}$ & 2.640 & $2.60^{y}$ & 8.787 \\
\hline & Hybrid & 1.406 & $0.899^{\mathrm{a}, \mathrm{x}}$ & $1.561^{\mathrm{c}, \mathrm{y}}$ & 0.893 & 4.832 & 2.570 & 1.875 & 1.98 & 8.328 & $8.563^{\mathrm{c}}$ & $3.244^{\mathrm{b}}$ & 2.594 & $5.01^{x}$ & 7.890 \\
\hline $\begin{array}{l}\text { Elevated } \\
\text { Nutrient }\end{array}$ & SS & 1.409 & $0.857^{\mathrm{ab}}$ & $1.641^{\mathrm{b}}$ & 0.360 & 4.741 & 2.622 & 1.795 & 2.70 & 9.107 & $9.269^{\mathrm{a}}$ & $3.499^{\mathrm{a}}$ & 2.599 & 4.06 & 8.294 \\
\hline $\mathrm{SEM}^{6}$ & - & 0.0507 & 0.0155 & 0.0199 & 0.0050 & 0.0769 & 0.0273 & 0.0171 & 0.4966 & 0.4229 & 0.4021 & 0.0509 & 0.0571 & 0.9693 & 0.3262 \\
\hline \multicolumn{16}{|c|}{ Probability } \\
\hline \multicolumn{2}{|c|}{ ANOVA } & 0.5787 & 0.0155 & 0.0015 & 0.2269 & 0.1013 & 0.1178 & 0.0512 & 0.6800 & 0.1349 & 0.0048 & 0.0255 & 0.7477 & 0.2850 & 0.1251 \\
\hline \multicolumn{2}{|c|}{$\begin{array}{l}\text { SS (basal) vs N700 vs } \\
\text { Hybrid }\end{array}$} & 0.6639 & 0.0180 & 0.0024 & 0.4480 & 0.0983 & 0.1882 & 0.3730 & 0.9992 & $\begin{array}{lll}- & - \\
\end{array}$ & 0.1536 & 0.1135 & 0.6179 & 0.0430 & - \\
\hline \multicolumn{2}{|c|}{ SS (basal) vs SS (EN) } & 0.4793 & 0.1690 & 0.1177 & 0.1167 & 0.0611 & 0.8746 & 0.1283 & 0.4834 & - & $\begin{array}{l}0.0329 \\
\end{array}$ & 0.2721 & 0.4373 & 0.4650 & - \\
\hline
\end{tabular}

${ }^{\mathrm{a}-\mathrm{d}}$ Means within a column with no common superscript differ significantly $(P<0.05)$.

${ }^{\mathrm{x}-\mathrm{z}}$ Means within a column with no common superscript differ significantly $(P<0.05)$.

${ }^{1} \mathrm{SS}=$ Super Select; N700 = Nicholas 700; Hybrid = Hybrid converter

${ }^{2} \mathrm{FI}=$ Feed Intake; EBW = End body weight; LWG = Live weight gain; Mort = Mortality

${ }^{3} \mathrm{FCR}=$ mortality corrected Feed Conversion Ratio

${ }^{4}$ Pooled SEM $(n=16)$ 
Table 4. Hen turkey performance from d 84-125

\begin{tabular}{|c|c|c|c|c|c|c|c|c|c|c|c|}
\hline & & \multicolumn{4}{|c|}{ d 84-111 } & & \multicolumn{4}{|c|}{ d 112-125 } & \\
\hline Diet & Strain $^{1}$ & $\begin{array}{c}\text { FI/bird }{ }^{2} \\
(\mathrm{~kg})\end{array}$ & $\begin{array}{c}\text { LWG/bird }{ }^{2} \\
(\mathrm{~kg})\end{array}$ & $\mathbf{F C R}^{3}$ & $\begin{array}{c}\text { Mort }^{2} \\
(\%)\end{array}$ & $\begin{array}{c}\mathrm{CV} \text { for } \mathrm{EBW}^{2} \\
(\%)\end{array}$ & $\begin{array}{c}\text { FI/bird }{ }^{2} \\
(\mathrm{~kg})\end{array}$ & $\begin{array}{c}\text { LWG/bird }^{2} \\
(\mathrm{~kg})\end{array}$ & $\mathbf{F C R}^{3}$ & $\begin{array}{c}\text { Mort }^{2} \\
(\%)\end{array}$ & $\begin{array}{c}\text { CV for } \mathrm{EBW}^{2} \\
(\%)\end{array}$ \\
\hline \multirow{3}{*}{ Basal } & SS & $10.366^{\mathrm{a}, \mathrm{x}}$ & $3.491^{\mathrm{a}, \mathrm{x}}$ & 2.910 & 4.77 & 8.355 & 4.565 & 1.446 & 3.22 & 1.40 & 8.310 \\
\hline & N700 & $10.429^{\mathrm{ab}, \mathrm{x}}$ & $3.473^{\mathrm{a}, \mathrm{x}}$ & 2.985 & 7.22 & 7.886 & 4.548 & 1.358 & 3.37 & 1.01 & 7.827 \\
\hline & Hybrid & $9.622^{b, y}$ & $3.216^{\mathrm{b}, \mathrm{y}}$ & 3.010 & 4.23 & 7.641 & 4.414 & 1.208 & 3.58 & 1.61 & 7.796 \\
\hline Elevated Nutrient & SS & $10.910^{\mathrm{a}}$ & $3.393^{\mathrm{a}}$ & 3.091 & 7.32 & 8.163 & 4.810 & 1.422 & 3.45 & 2.05 & 8.498 \\
\hline SEM $^{6}$ & & 0.6053 & 0.0425 & 0.0475 & 0.9387 & 0.3510 & 0.1996 & 0.0755 & 0.0523 & 0.4181 & 0.4326 \\
\hline \multicolumn{12}{|c|}{ Probability } \\
\hline \multicolumn{2}{|l|}{ ANOVA } & 0.0408 & 0.0050 & 0.1286 & 0.0904 & 0.5266 & 0.28 & 0.1836 & 0.4321 & 0.4086 & 0.5987 \\
\hline \multirow{2}{*}{\multicolumn{2}{|c|}{ SS (basal) vs N700 vs Hybrid }} & 0.0410 & 0.0110 & 0.3497 & 0.0787 & - & 0.42 & 0.2066 & 0.3396 & 0.6421 & - \\
\hline & $(\mathrm{EN})$ & 0.5202 & 0.0570 & 0.0414 & 0.2840 & - & 0.70 & 0.8588 & 0.3932 & 0.0483 & - \\
\hline
\end{tabular}

${ }^{\mathrm{a}-\mathrm{d}}$ Means within a column with no common superscript differ significantly $(P<0.05)$.

${ }^{\mathrm{x}-\mathrm{z}}$ Means within a column with no common superscript differ significantly $(P<0.05)$.

${ }^{1} \mathrm{SS}=$ Super Select; N700 = Nicholas 700; Hybrid = Hybrid converter

${ }^{2} \mathrm{FI}=$ Feed Intake; EBW = End body weight; LWG = Live weight gain; Mort = Mortality

${ }^{3} \mathrm{FCR}=$ mortality corrected Feed Conversion Ratio

${ }^{4}$ Pooled SEM $(n=16)$ 
Table 5. Overall (d 1-125) hen turkey performance

\begin{tabular}{|c|c|c|c|c|c|c|c|}
\hline Diet & Strain $^{1}$ & $\begin{array}{c}\text { FI/bird }{ }^{2} \\
(\mathrm{~kg})\end{array}$ & $\begin{array}{c}\mathbf{E B W}^{2} \\
(\mathrm{~kg})\end{array}$ & $\begin{array}{c}\text { LWG/bird }^{2} \\
(\mathrm{~kg})\end{array}$ & $\mathbf{F C R}^{3}$ & $\operatorname{Mort}^{2} \%$ & $\begin{array}{c}\text { CV for } \\
\text { EBW } \\
(\%)\end{array}$ \\
\hline \multirow{3}{*}{ Basal } & SS & $30.000^{\mathrm{ab}}$ & 11.829 & 11.768 & 2.506 & 12.14 & 8.310 \\
\hline & N700 & $29.727^{\text {bc }}$ & 11.559 & 11.504 & 2.553 & 12.68 & 7.827 \\
\hline & Hybrid & $28.837^{\mathrm{c}}$ & 11.213 & 11.157 & 2.544 & 13.04 & 7.796 \\
\hline Elevated Nutrient & SS & $31.137^{\mathrm{a}}$ & 11.855 & 11.793 & 2.562 & 15.59 & 8.498 \\
\hline $\mathrm{SEM}^{4}$ & - & 1.0305 & 0.1674 & 0.1673 & 0.0267 & 1.3301 & 0.4326 \\
\hline \multicolumn{8}{|c|}{ Probability } \\
\hline ANOVA & & 0.0184 & 0.0774 & 0.0802 & 0.4931 & 0.3269 & 0.5987 \\
\hline SS (basal) vs N700 vs Hybrid & & 0.0701 & 0.1429 & 0.1458 & 0.3569 & 0.7365 & - \\
\hline SS (basal) vs SS (EN) & & 0.1611 & 0.9126 & 0.9141 & 0.2067 & 0.3439 & - \\
\hline
\end{tabular}

${ }^{a-d}$ Means within a column with no common superscript differ significantly $(P<0.05)$.

${ }^{\mathrm{x}-\mathrm{z}}$ Means within a column with no common superscript differ significantly $(P<0.05)$.

${ }^{1} \mathrm{SS}=$ Super Select; $\mathrm{N700}=$ Nicholas 700; Hybrid $=$ Hybrid converter

${ }^{2} \mathrm{FI}=$ Feed Intake; EBW = End body weight; $\mathrm{LWG}=$ Live weight gain; Mort = Mortality

${ }^{3} \mathrm{FCR}=$ mortality corrected Feed Conversion Ratio

${ }^{4}$ Pooled SEM $(\mathrm{n}=16)$ 
Table 6. Feather scoring descriptive data ${ }^{1,2}$ (d 56 and d 112)

\begin{tabular}{|c|c|c|c|c|c|}
\hline Treatment $^{3}$ & Dorsal & Thigh & Keel & Neck & Overall \\
\hline & \multicolumn{5}{|c|}{ d 56} \\
\hline SS (Basal) & 4.7 & 4.4 & 4.8 & - & 4.6 \\
\hline N700 & 4.8 & 4.3 & 4.7 & - & 4.6 \\
\hline Hybrid & 5.0 & 4.6 & 4.9 & - & 4.8 \\
\hline \multirow[t]{2}{*}{ SS (EN) } & 4.7 & 4.4 & 4.7 & - & 4.6 \\
\hline & \multicolumn{5}{|c|}{ d 112} \\
\hline SS (Basal) & 4.9 & 5.0 & - & 3.5 & 4.5 \\
\hline N700 & 4.9 & 5.0 & - & 3.6 & 4.5 \\
\hline Hybrid & 5.0 & 5.0 & - & 4.4 & 4.8 \\
\hline SS (EN) & 5.0 & 5.0 & - & 4.2 & 4.7 \\
\hline
\end{tabular}

${ }^{1}$ Rated using 5 -point likert scale $(0=$ no feather coverage $-5=$ full feather coverage $)$

${ }^{2}$ Feather score ratings were determined by trained individual (20 poults/pen).

${ }^{3}$ SS $=$ Super Select; N700 = Nicholas 700; Hybrid $=$ Hybrid converter 
Table 7. d 125 hot carcass characteristics and LKR activity

\begin{tabular}{|c|c|c|c|c|c|c|}
\hline Diet & Strain $^{1}$ & $\begin{array}{c}\text { Breast } \\
\text { Weight }(\mathrm{g})\end{array}$ & $\begin{array}{c}\text { Breast Yield } \\
(\%)\end{array}$ & $\begin{array}{c}\text { Fat Pad } \\
\text { Weight (g) }\end{array}$ & $\begin{array}{c}\text { Fat Pad Yield } \\
(\%)\end{array}$ & $\begin{array}{c}\text { LKR Activity }^{2} \\
\text { (moles/min } * \mathbf{g} \\
\text { liver) }\end{array}$ \\
\hline \multirow{3}{*}{ Basal } & SS & 2872.0 & 22.80 & 259.65 & 2.07 & $5.42 \mathrm{E}-08$ \\
\hline & N700 & 2527.6 & 21.32 & 241.65 & 2.06 & 0 \\
\hline & Hybrid & 2597.0 & 21.01 & 280.43 & 2.27 & $2.06 \mathrm{E}-07$ \\
\hline Elevated Nutrient & SS & 2373.9 & 22.03 & 191.70 & 1.79 & $1.11 \mathrm{E}-07$ \\
\hline \multicolumn{2}{|c|}{ SEM } & 191.2921 & 0.8895 & 25.2847 & 0.1931 & $6.109 \mathrm{E}-0.8$ \\
\hline \multicolumn{7}{|c|}{ Probability } \\
\hline \multicolumn{2}{|c|}{ ANOVA } & 0.3688 & 0.5241 & 0.1520 & 0.4206 & 0.1748 \\
\hline \multicolumn{2}{|c|}{ SS (basal) vs N700 vs Hybrid } & 0.3925 & 0.2833 & 0.6606 & 0.7739 & 0.1409 \\
\hline \multicolumn{2}{|c|}{ SS (basal) vs SS (EN) } & 0.1125 & 0.4481 & 0.0551 & 0.1602 & 0.4246 \\
\hline
\end{tabular}

${ }^{\mathrm{a}-\mathrm{d}}$ Means within a column with no common superscript differ significantly $(P<0.05)$.

${ }^{\mathrm{x}-\mathrm{z}}$ Means within a column with no common superscript differ significantly $(P<0.05)$.

${ }^{1} \mathrm{SS}=$ Super Select; $\mathrm{N700}=$ Nicholas 700; Hybrid $=$ Hybrid converter

${ }^{2} \Delta \mathrm{Abs}_{\text {net }}=\Delta \mathrm{Abs}_{+}$Lys $-\Delta \mathrm{Abs}_{\text {- Lys }} @ 340 \mathrm{~nm}=\Delta$ moles NADPH 
Table 8. Carcass yield descriptive data ${ }^{1}$ from commercial processing plant on d 126

\begin{tabular}{|c|c|c|c|c|c|c|c|c|c|c|c|}
\hline \multirow{2}{*}{ Diet } & Strain $^{2}$ & $\begin{array}{c}\mathrm{WOG}^{3} \\
(\mathrm{~kg})\end{array}$ & $\begin{array}{c}\text { Front } \\
\text { Half } \\
(\%)\end{array}$ & $\begin{array}{c}\text { Hind } \\
\text { Half } \\
(\%)\end{array}$ & $\begin{array}{c}\text { Tender } \\
\text { w/ } \\
\text { Strap } \\
(\%)\end{array}$ & $\begin{array}{c}\text { Scapula } \\
\text { w/ Skin } \\
(\%)\end{array}$ & $\begin{array}{c}\text { Breast } \\
\text { Skin } \\
(\%)\end{array}$ & $\begin{array}{c}\text { Whole } \\
\text { Wing } \\
(\%)\end{array}$ & $\begin{array}{c}\text { Drum } \\
(\%)\end{array}$ & $\begin{array}{c}\text { B/S } \\
\text { Thigh } \\
\text { Meat } \\
(\%)\end{array}$ & $\begin{array}{c}\text { B/S } \\
\text { Breast } \\
\text { Yield } \\
(\%)\end{array}$ \\
\hline \multirow{3}{*}{ Basal } & SS & 9.495 & 61.19 & 38.16 & 6.37 & 2.01 & 6.27 & 10.57 & 11.25 & 10.13 & 23.34 \\
\cline { 2 - 12 } & N700 & 9.507 & 60.95 & 39.02 & 6.14 & 2.94 & 6.19 & 10.73 & 11.56 & 10.32 & 22.50 \\
\cline { 2 - 11 } & Hybrid & 9.022 & 60.24 & 39.79 & 5.81 & 1.98 & 6.69 & 10.63 & 12.02 & 10.64 & 22.01 \\
\hline $\begin{array}{l}\text { Elevated } \\
\text { Nutrient }\end{array}$ & SS & 9.722 & 61.27 & 37.95 & 6.43 & 1.97 & 5.91 & 10.60 & 11.44 & 10.14 & 23.50 \\
\hline
\end{tabular}

${ }^{1} \mathrm{n}=50$ per treatment

${ }^{2} \mathrm{SS}=$ Super Select; N700 = Nicholas 700; Hybrid = Hybrid converter

${ }^{3} \mathrm{WOG}=$ weigh omitting giblets; $\mathrm{B} / \mathrm{S}=$ boneless/skinless; $\mathrm{BI}=$ bone-in 


\section{EMPLOYMENT}

Graduate Research Assistant

June 2014-Current

Department of Animal \& Nutritional Sciences

West Virginia University

Farm and Facility Manager

June 2007-July 2014

Foltz Litter, Inc.

Mathias, $W V$

\section{EDUCATION}

MASTER OF SCIENCE

GPA: 3.60

Animal and Food Science

YEARS ATTENDED (2014-CURRENT)

West Virginia University

Morgantown, $W V$

Thesis: Nutritional consequences of various ingredients in broilers, turkeys, and swine

\section{BACHELOR OF SCIENCE}

Biochemistry

GPA: 3.70

Minor: Applied Environmental Microbiology

West Virginia University

YEARS ATTENDED (2010-2014)

Morgantown, WV

\section{PUBLICATIONS}

\section{PEER-REVIEWED MANUSCRIPTS:}

Foltz, K.L., B.G. Glover and J.S. Moritz. 2016. Effect of zinc supplementation source and corn particle size on 40-day broiler performance. J. Appl. Poult. Res. (In Review)

Foltz, K. L., D. L. Smith, and J. S. Moritz. 2016. Porcine palatability of corn-soybean based diets supplemented with oil-extracted microalgae and subsequent performance. Prof. Anim. Sci. (In Preparation) 
Foltz, K. L., O. Gutierrez, and J. S. Moritz. 2016. Transgenic phytase corn and granulated phytase effects on mix uniformity, thermal stability, and pellet quality. J. Appl. Poult. Sci. (In Preparation)

Reese, D. A., K. L. Foltz, and J. S. Moritz. 2016. Effect of mixing and sampling on pelleted feed nutrient analysis and diet formulation validation. J. Appl. Poult. Res. (In Preparation)

Glover, B.G., K.L. Foltz, I. Holásková and J.S. Moritz. 2016. Effects of modest improvements in pellet quality and experiment pen size on broiler chicken performance. J. Appl. Poult. Res. 25:21-28.

\section{ABSTRACTS:}

Glover, B. G., K. L. Foltz, K. J. Ryan, and J. S. Moritz. 2016. Effects of feed form, environment, and caloric density on energy partitioning and subsequent performance. Poult. Sci. Vol. 95.

Foltz, K.L. and J.S. Moritz. 2015. Effect of zinc supplementation source and corn particle size on 40-day broiler performance. Poult. Sci. Vol. 94 (E-Suppl. 1): 104

Reese, D.A., K.L. Foltz, and J.S. Moritz. 2015. The effect of feed mixing and sampling variables on nutrient analysis. Poult. Sci. Vol. 94 (E-Supple. 1): 101

Foltz, K.L. and J.S. Moritz. 2015. Effect of organic and inorganic zinc supplementation and corn particle size on 40-day broiler performance. Mid-Atlantic Nutr. Conf. March 24-25.

Reese, D.A., K.L. Foltz, and J.S. Moritz. 2015. The effect of feed mixing and sampling variables on nutrient analysis. Mid-Atlantic Nutr. Conf. March 24-25.

\section{RESEARCH EXPERIENCE}

GRADUATE RESEARCH ASSISTANT:

June 2014-Current

- Contract studies with H.J. Baker \& Bro., Anitox, Huvepharma, Greenwood Nutrition, Sapphire Energy, Aviagen Turkeys, Verenium, Virginia Poultry Grower's Coop, Alltech, Nutech Biosciences, and DSM

- Conducted study assessing mix uniformity and thermal stability of transgenic phytase corn (Feb 2016)

- Assisted study determining the effect of feed form and ME on energy partitioning in a broiler model (Jan-Apr 2016)

- Assisted with study evaluating areas of concerns when pelleting feed (Dec 2015) 
- Assisted with trial examining efficacy of rumen protected lysine in broiler chickens d 121 (Dec 2015)

- Conducted broiler performance trial assessing various probiotics in mash feed d 1-16 (Oct 2015)

- Assisted with study evaluating broiler performance and viscosity of novel xylanase products fed as unprocessed mash d 1-21 (Aug-Sep 2015)

- Conducted study on palatability and performance of young grower pigs fed a cornsoybean meal based diet supplemented with defatted Spirulina algae byproduct (MayAug 2015)

- Assisted with protease enzyme heat stability and retention pelleting trial (Aug 2015)

- Conducted study assessing performance and processing differences among three genetic strains of hen turkeys, and the effect of an increased nutrient diet on feathering and performance of one select strain (Feb-Jun 2015)

- Co-conducted study determining proper and adequate sampling methodologies within the feed mill (Jan-Feb 2015)

- Assisted with study examining the effects of feed form and pen size on broiler performance (Oct-Nov 2014)

- Assisted with study evaluating performance, ileal AA digestibility, digestive viscosity, and tibia ash in broilers fed diets including poultry litter biochar (PLB) (Oct 2014)

- Assisted with study examining the interaction between pellet quality and feeder space access (Sep 2014)

- Assisted study utilizing a full fat Spirulina algae product as a nutritive pellet binder (Aug 2014)

- Conducted trial examining the effects of zinc supplementation source and corn particle size on broiler performance (Apr-May 2014)

- Assisted study evaluating feed form effects on tom turkey growth (Feb-May 2014)

- Assisted with study examining effects of super doses of phytase on tibia ash and broiler performance (Dec 2013-Jan 2014)

\section{NATIONAL MEETING PRESENTATIONS:}

- 2015 Poultry Science Association Annual Meeting (Louisville, KY) - Oral presentation titled "Effect of zinc supplementation source and corn particle size on 40-day broiler performance"

- 2015 Mid-Atlantic Nutrition Conference (Timonium, MD) - Poster presentation titled "Effect of organic and inorganic zinc supplementation and corn particle size on 40-day broiler performance" ( 2 nd place graduate competition) 


\section{PROFESSIONAL DEVELOPMENT:}

- International Poultry Scientific Forum, Atlanta, GA (2016)

- International Production \& Processing Expo, Atlanta, GA (2016)

- Poultry Science Association Annual Meeting, Louisville, KY (2015)

- Mid-Atlantic Nutrition Conference, Timonium, MD (2015)

- Poultry Science Association Annual Meeting, Corpus Cristi, TX (2014)

\section{TEACHING EXPERIENCE}

- Guest lecturer for A\&VS 251 (Fall 2014 \& 2015)

- Teaching assistant for Poultry Evaluation course - ANPR 339 (Spring 2015 \& 2016)

- Teaching assistant for Poultry Production course lab - ANPR 369 (Fall 2014)

\section{EXTENSION EXPERIENCE}

- Presenter at Marion County Hands-on Ag Day (Sep 2015)

- Presentation and feed mill demonstration for WV Governor's Honors Academy students (July 2015)

- WV FFA CDE Poultry Judging Competition at Cedar Lakes, WV (July 2015)

- Presenter at WVU Extension SARE workshop in Marshall County (Apr 2015)

- Presentation and poultry processing demonstration at WVU Extension SARE workshop in Gilmer Country (Oct 2014)

- Presenter at Marion County Hands-on Ag Day (Sep 2014)

- WV Poultry Association 4-H judging competition (July 2014)

- Attended WV Poultry Association annual meeting in Moorefield, WV (July 2014)

- Presentation and processing demonstration at WVU Extension workshop in Monongalia County (June 2014)

- WV Urban Ag Conference - Presentation and processing demonstration for backyard poultry producers in WV (Apr 2014)

- WV FFA CDE Poultry Judging Competition at WVU (Apr 2014)

- Presentation and processing demonstration at WVU SARE Extension workshop in Preston County (Mar 2014)

\section{ACADEMIC HONORS/AWARDS}

\section{AWARDS AND HONORS:}

- Assistant coach for WVU Poultry Judging team (Spring 2015 \& 2016) 
- Team placed $4^{\text {th }}$ overall at 2015 U.S. Poultry \& Egg Association National Poultry Judging Contest in Baton Rouge, LA

- $2^{\text {nd }}$ place in Graduate Poster Competition at 2015 Mid-Atlantic Nutrition Conference

- Member of Alpha Lambda Delta Honor Society (Sep 2012)

\section{SCHOLARSHIPS:}

- VT College of Agriculture and Life Sciences Dean Scholar Award (2016)

- WV PROMISE Scholarship (2010-2014)

- WVU Mountaineer Scholarship (2010-2014)

- WVU Alumni Association Loyalty Permanent Endowment Fund Valedictorian Scholarship (2010-2014)

- Lost River Ministerial Association Scholarship (2010) 